\title{
Development of (4-Cyanophenyl)glycine Derivatives as Reversible Inhibitors of Lysine Specific Demethylase 1
}

DOI:

10.1021/acs.jmedchem.7b00462

\section{Document Version}

Accepted author manuscript

Link to publication record in Manchester Research Explorer

\section{Citation for published version (APA):}

Mould, D., Alli, C., Bremberg, U., Cartic, S., Jordan, A., Geitmann, M., Maiques-Diaz, A., Mcgonagle, A., Somervaille, T., Spencer, G., Turlais, F., \& Ogilvie, D. (2017). Development of (4-Cyanophenyl)glycine Derivatives as Reversible Inhibitors of Lysine Specific Demethylase 1. Journal of Medicinal Chemistry.

https://doi.org/10.1021/acs.jmedchem.7b00462

\section{Published in:}

Journal of Medicinal Chemistry

\section{Citing this paper}

Please note that where the full-text provided on Manchester Research Explorer is the Author Accepted Manuscript or Proof version this may differ from the final Published version. If citing, it is advised that you check and use the publisher's definitive version.

\section{General rights}

Copyright and moral rights for the publications made accessible in the Research Explorer are retained by the authors and/or other copyright owners and it is a condition of accessing publications that users recognise and abide by the legal requirements associated with these rights.

\section{Takedown policy}

If you believe that this document breaches copyright please refer to the University of Manchester's Takedown Procedures [http://man.ac.uk/04Y6Bo] or contact uml.scholarlycommunications@manchester.ac.uk providing relevant details, so we can investigate your claim.

\section{OPEN ACCESS}


Journal of

Medicinal Chemistry

Subscriber access provided by The University of Manchester Library

Article

\section{Development of (4-Cyanophenyl)glycine Derivatives as Reversible Inhibitors of Lysine Specific Demethylase 1}

Daniel P. Mould, Cristina Alli, Ulf Bremberg, Sharon Cartic, Allan M. Jordan, Matthis Geitmann, Alba MaiquesDiaz, Alison E McGonagle, Tim C. P. Somervaille, Gary J. Spencer, Fabrice Turlais, and Donald J. Ogilvie

J. Med. Chem., Just Accepted Manuscript • DOI: 10.1021/acs.jmedchem.7b00462 • Publication Date (Web): 11 Sep 2017

Downloaded from http://pubs.acs.org on September 12, 2017

\section{Just Accepted}

"Just Accepted" manuscripts have been peer-reviewed and accepted for publication. They are posted online prior to technical editing, formatting for publication and author proofing. The American Chemical Society provides "Just Accepted" as a free service to the research community to expedite the dissemination of scientific material as soon as possible after acceptance. "Just Accepted" manuscripts appear in full in PDF format accompanied by an HTML abstract. "Just Accepted" manuscripts have been fully peer reviewed, but should not be considered the official version of record. They are accessible to all readers and citable by the Digital Object Identifier (DOI®). "Just Accepted" is an optional service offered to authors. Therefore, the "Just Accepted" Web site may not include all articles that will be published in the journal. After a manuscript is technically edited and formatted, it will be removed from the "Just Accepted" Web site and published as an ASAP article. Note that technical editing may introduce minor changes to the manuscript text and/or graphics which could affect content, and all legal disclaimers and ethical guidelines that apply to the journal pertain. ACS cannot be held responsible for errors or consequences arising from the use of information contained in these "Just Accepted" manuscripts. 


\title{
Development of (4-Cyanophenyl)glycine Derivatives as Reversible Inhibitors of Lysine Specific \\ Demethylase 1
}

Daniel P. Mould ${ }^{\dagger}$, Cristina Alli ${ }^{\perp}$, Ulf Bremberg ${ }^{\S}$, Sharon Cartic ${ }^{\perp}$, Allan M. Jordan ${ }^{\dagger, *}$, Matthis

Geitmann $^{\S}$, Alba Maiques-Diaz ${ }^{\ddagger}$, Alison E. McGonagle ${ }^{\dagger}$, Tim C. P. Somervaille ${ }^{\ddagger}$, Gary J. Spencer ${ }^{\ddagger}$, Fabrice Turlais ${ }^{\perp}$, and Donald Ogilvie ${ }^{\dagger}$

\author{
${ }^{\dagger}$ Drug Discovery Unit, Cancer Research UK Manchester Institute, University of Manchester, \\ Wilmslow Road, Manchester, M20 4BX, UK \\ *Leukaemia Biology Laboratory, Cancer Research UK Manchester Institute, University of \\ Manchester, Wilmslow Road, Manchester, M20 4BX, UK \\ ${ }^{\S}$ Beactica AB, Uppsala Business Park, Virdings allé 2, 75450, Uppsala, SE \\ ${ }^{\perp}$ CRT Discovery Laboratories, Babraham Campus, Babraham, Cambridgeshire, CB22 3AT, UK
}




\begin{abstract}
Inhibition of lysine specific demethylase 1 (LSD1) has been shown to induce the differentiation of leukemia stem cells in acute myeloid leukaemia (AML). Irreversible inhibitors developed from the non-specific inhibitor tranylcypromine have entered clinical trials; however, the development of effective reversible inhibitors has proved more challenging. Herein, we describe our efforts to identify reversible inhibitors of LSD1 from a high throughput screen, and subsequent in silico modelling approaches. From a single hit (12) validated by biochemical and biophysical assays, we describe our efforts to develop acyclic scaffold-hops from GSK-690 (1). A further scaffold modification to a (4cyanophenyl)glycinamide (e.g. 29a) led to the development of compound 32, with a $K_{\mathrm{d}}$ value of 32 $\mathrm{nM}$ and an $\mathrm{EC}_{50}$ value of $0.67 \mu \mathrm{M}$ in a surrogate cellular biomarker assay. Moreover, this derivative does not display the same level of hERG liability as observed with $\mathbf{1}$ and represents a promising lead for further development.
\end{abstract}




\section{Introduction}

Lysine specific demethylase 1 (LSD1) was the first histone demethylase to be discovered, ${ }^{1}$ and has been found to play an important role in normal and malignant cells as a transcriptional repressor. ${ }^{2}$ LSD1 belongs to the FAD-dependent amine oxidase family of demethylases and catalyzes the demethylation of lysine residues of histones, ${ }^{3}$ specifically $\mathrm{H} 3 \mathrm{~K} 4 \mathrm{me} 1 / 2$ and H3K9me1/2. ${ }^{4}$ Aside from this role, it has become clear that LSD1 plays important scaffolding roles as part of the CoREST complex, ${ }^{5}$ especially in controlling the interaction with transcription factors such as growth factor independence (GFI) 1 and $1 \mathrm{~b} \cdot{ }^{6-7}$ LSD1 and GFI1 in combination appear to balance the regulation of hematopoietic cell proliferation and differentiation in hematopoietic stem and progenitor cells. ${ }^{8}$ GFI1 interacts with LSD1 through binding of its C-terminal SNAG domain in the active site of LSD1, suggesting that LSD1 inhibitors may induce their phenotype through abrogation of this proteinprotein interaction, and the downstream changes in gene expression this effects, rather than by inhibition of histone demethylation. ${ }^{9}$ In addition, it has been established that LSD1 plays a key role in acute myeloid leukaemia (AML) driven by mixed lineage leukaemia (MLL) fusions, ${ }^{10}$ whereby overexpression of LSD1 maintains malignant stem and progenitor cells in a self-renewing state. This has helped to establish a novel treatment hypothesis in a hematological malignancy where the standard of care has changed little in the past three decades. ${ }^{11}$

There is also evidence that LSD1 inhibition could have a beneficial effect in a number of other disease areas. It has been shown that small cell lung cancer cell lines have high levels of LSD1 overexpression in almost all cases, and some show sensitivity to LSD1 inhibition in vitro and in tumour xenografts. ${ }^{12}$ The authors suggest a correlation between response and DNA hypomethylation. The consequence of inhibition is similar to AML, in that cells show a differentiation phenotype towards their original neuroendocrine state. LSD1 inhibition has also shown promise for the treatment of herpes simplex infection, ${ }^{13,14}$ memory deficit, ${ }^{15}$ and patents have been filed describing the potential use of LSD1 inhibitors in diseases associated with alterations in protein conformation, such as Alzheimer's, Parkinson's and Huntingdon's diseases. ${ }^{16,}{ }^{17}$ Irreversible inhibitors of LSD1 developed from the clinical monoamine oxidase (MAO) inhibitor tranylcypromine entered clinical trials in 2014. 
These inhibitors will provide valuable insights into the validation of targeting malignant stem and progenitor cells in AML patients. Preliminary clinical trials data of $r e l-\mathrm{N}^{1}-[(1 \mathrm{R}, 2 \mathrm{~S})-2-$ phenylcyclopropyl]-1,4-cyclohexanediamine (ORY-1001, Oryzon Genomics) has demonstrated promotion of blast cell differentiation in roughly two-thirds of patients in an extension cohort with specific subtypes of relapsed or refractory AML, although adverse effects limited the maximum tolerated dose. ${ }^{18}$ Additional clinical trials are underway with tranylcypromine derivatives from GlaxoSmithKline (Clinicaltrials.gov identifier NCT02177812), ${ }^{19}$ and Incyte Corporation (Clinicaltrials.gov identifier NCT02712905), ${ }^{20}$ although no results have yet been disclosed. The clinical efficacy of LSD1 inhibitors may ultimately be enhanced by way of combination therapies. For example, all-trans-retinoic acid (ATRA) therapy is already successfully used as a differentiation therapy in acute promyelocytic leukaemia (APL), and research has suggested addition of an LSD1 inhibitor could enable this therapy to be more widely applicable to AML. ${ }^{21}$ Emerging data suggests the wider applicability of this strategy to other epigenetic targets such as bromodomains, ${ }^{22}$ and histone deacetylases. $^{23}$

The development of reversible LSD1 inhibitors is not trivial, due to the large size and polarity of the LSD1 substrate binding pocket. As such, progress has not matched that of the covalent inactivators of LSD1. ${ }^{24}$ Reversible inhibitors such as GSK-690 (1, Figure 1) have achieved good potency in biochemical and cellular assays, ${ }^{25}$ however this compound strongly inhibits the human ether-a-go-gorelated gene (hERG) cardiac ion channel, which prevented the progression of this series to the clinic. ${ }^{26}$ Many other published reversible inhibitor series appear to have significant off-target and non-specific effects. $^{24}$ In the past year, it has become apparent that there is commercial interest in developing reversible inhibitors, as evidenced by a number of patent applications from Quanticel Pharmaceuticals (2-6, Figure 1) and Celgene. ${ }^{27-32}$ Recently, the discovery and optimization of a series of thieno[3,2b]pyrrole-5-carboxamides, and the crystal structures of quinazoline based reversible inhibitors has also been described. ${ }^{33-35}$ 


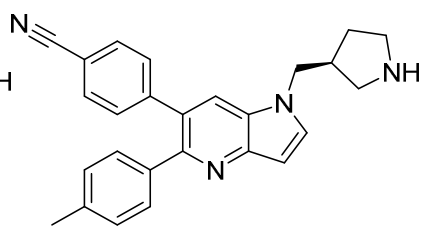

2
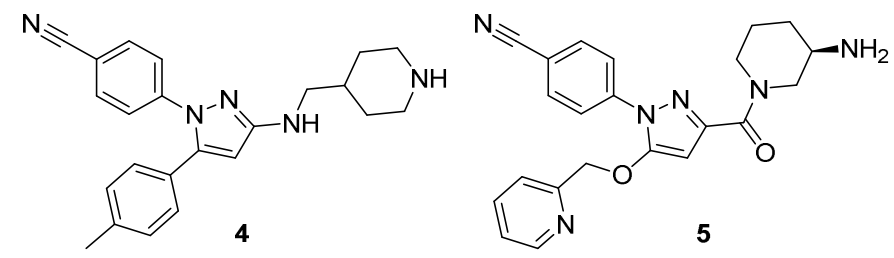

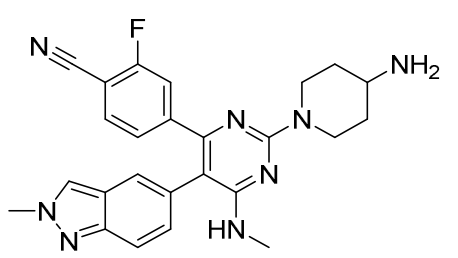

3

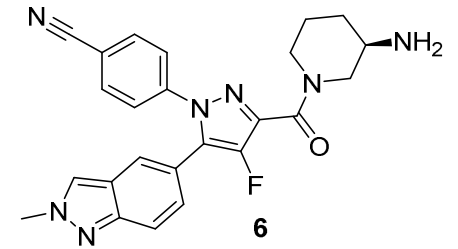

Figure 1. Compound 1 and examples from several series disclosed by Quanticel Pharmaceuticals(26). ${ }^{28}$

Herein, we describe our efforts towards the development of reversible inhibitors of LSD1 identified by high-throughput screening, and using in silico design to develop sub-micromolar inhibitors of LSD1 that show activity in cellular assays.

\section{Chemistry}

Aniline 9 (Scheme 1) was prepared from nitrobenzene 7 via aromatic nucleophilic substitution with 3,5-dimethylpyrazole to afford $\mathbf{8}$, which was reduced with zinc metal and ammonium formate. Aniline 9 was reacted with the requisite sulfonyl chloride in pyridine to afford compounds $\mathbf{1 0 a}-\mathbf{b}$. As described in Scheme 2, compound $\mathbf{1 2}$ was formed by the reaction of aniline $\mathbf{1 1}$ with 4acetatamidobenzenesulfonyl chloride. Compound $\mathbf{1 1}$ was also reacted with 4-methylphenylsulfonyl chloride in acetonitrile in the presence of pyridine to afford sulfonamide $\mathbf{1 3}$. Compound $\mathbf{1 3}$ was alkylated with tert-butyl bromoacetate to afford the ester 14. Deprotection with trifluoroacetic acid afforded acid $\mathbf{1 5}$ as a key intermediate. ${ }^{36}$ This was reacted with a variety of di-amines under standard amide coupling conditions, with a Boc-deprotection step using $4 \mathrm{M} \mathrm{HCl} /$ dioxane if required, to give amides 16a-m. Sulfonamides 18-20 were formed under standard conditions, then alkylated with a Boc-protected chloroacetylpiperidine derivative (see Supporting Information for synthesis) to afford derivatives 21-23 (Scheme 3). To synthesize the methylene replacement analogues (Scheme 4), 
commercially available (4-cyanophenyl)glycine was reacted with a variety of Boc-protected substituted piperidines under standard amide coupling conditions to afford intermediates 25-28. Alkylation with a variety of substituted benzyl bromides in DMF in the presence of potassium carbonate, and subsequent Boc-deprotection, afforded compounds 29a-e, 30a-f, 31 and 32.

Scheme 1: Synthesis of compounds $10 a-b^{a}$

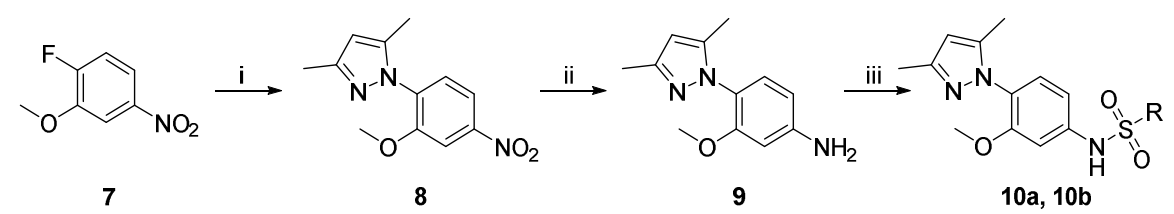

${ }^{a}$ Reagents and conditions: (i) 3,5-dimethylpyrazole, $\mathrm{K}_{2} \mathrm{CO}_{3}$, DMF, $80{ }^{\circ} \mathrm{C}, 16 \mathrm{~h}, 99 \%$; (ii) $\mathrm{Zn}$, ammonium formate, $\mathrm{MeOH}, 40{ }^{\circ} \mathrm{C}, 16 \mathrm{~h}, 78 \%$; (iii) appropriate sulfonyl chloride, pyridine, $100{ }^{\circ} \mathrm{C}, 1$ h, $41-70 \%$.

Scheme 2: Synthesis of compounds 12 and $16 a-m^{a}$

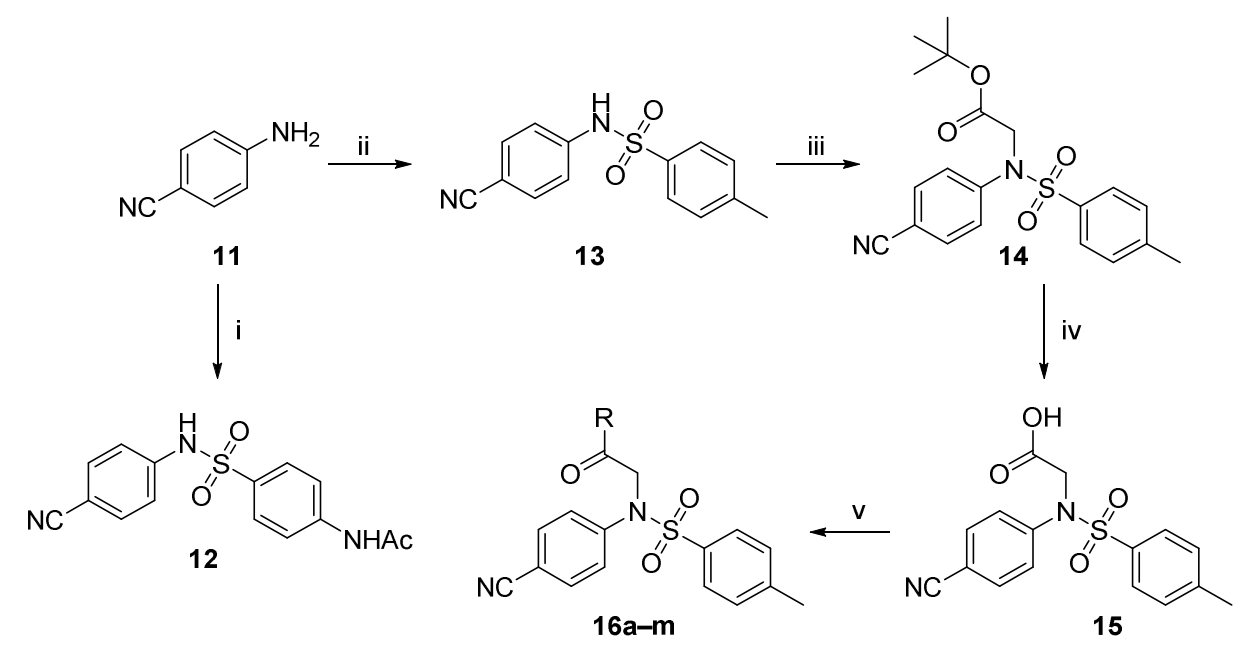

${ }^{a}$ Reagents and conditions: (i) 4-acetamidobenzenesulfonyl chloride, DMAP, MeCN, $\mu \mathrm{W}, 100{ }^{\circ} \mathrm{C}, 1 \mathrm{~h}$, 37\%; (ii) 4-methylphenylsulfonyl, pyridine, $\mathrm{MeCN}, \mathrm{RT}, 12 \mathrm{~h}, 89 \%$; (iii) tert-butyl bromoacetate, $\mathrm{K}_{2} \mathrm{CO}_{3}$, DMF, $1 \mathrm{~h}, 96 \%$; (iv) TFA, DCM, $1 \mathrm{~h}, 98 \%$; (v) amine, DIPEA, COMU, DMF, then 4M $\mathrm{HCl} /$ dioxane if Boc deprotection required, RT, 12-68\%. 
Scheme 3: Synthesis of compounds $21 \mathrm{a}-\mathrm{b}, 22$ and $23^{a}$

${ }^{a}$ Reagents and conditions: (i) 1-acetylindoline-5-sulfonyl chloride, pyridine, MeCN, RT, 12 h, 84\%;

(ii) (21a) tert-butyl $N$-[(3R)-1-(2-chloroacetyl)-3-piperidyl $]$ carbamate, $\mathrm{K}_{2} \mathrm{CO}_{3}$, cat. $\mathrm{KI}, \mathrm{DMF}, 80{ }^{\circ} \mathrm{C}, 3$ h; then TFA, 1 h, rt, 42\%; (21b) tert-butyl N-[1-(2-chloroacetyl)-4-piperidyl]carbamate, $\mathrm{K}_{2} \mathrm{CO}_{3}, 80$ ${ }^{\circ} \mathrm{C}, 6 \mathrm{~h}$, then $4 \mathrm{M} \mathrm{HCl} /$ dioxane, 70\%; (iii) 2-methyl-2H-indazol-5-amine, pyridine, MeCN, rt, $12 \mathrm{~h}$, 54\%; (iv) tert-butyl $N$-[(3R)-1-(2-chloroacetyl)-3-piperidyl]carbamate, $\mathrm{K}_{2} \mathrm{CO}_{3}$, cat. $\mathrm{KI}, \mathrm{DMF}, 80^{\circ} \mathrm{C}, 3$ h; then TFA, 1 h, rt, 25\%; (v) 1-acetylindoline-5-sulfonyl chloride, pyridine, MeCN, RT, 12 h, 54\%; (vi) tert-butyl N-[1-(2-chloroacetyl)-4-piperidyl]carbamate, $\mathrm{K}_{2} \mathrm{CO}_{3}, \mathrm{DMF}, 80{ }^{\circ} \mathrm{C}, 6 \mathrm{~h}$, then $4 \mathrm{M}$ $\mathrm{HCl} /$ dioxane, $1 \mathrm{~h} \mathrm{RT}, 52 \%$. 
Scheme 4: Synthesis of compounds $29 a-e, 30 a-f, 31$ and $32^{a}$

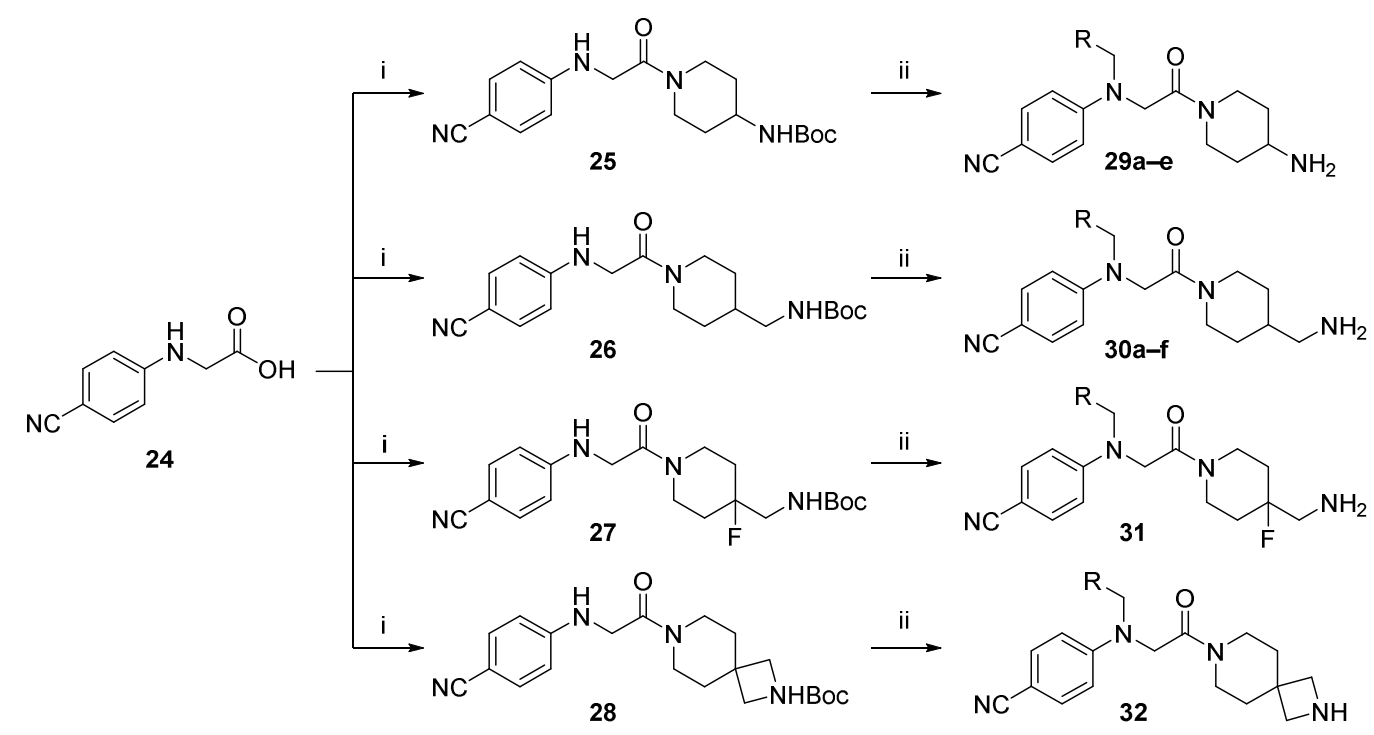

${ }^{a}$ Reagents and conditions: i) Boc-protected diamine, DIPEA, COMU, DMF, rt, 1 h, $67-99 \%$; ii) substituted benzyl-bromide, $\mathrm{K}_{2} \mathrm{CO}_{3}$, DMF, $80^{\circ} \mathrm{C}, 1 \mathrm{~h}$, then $4 \mathrm{M} \mathrm{HCl} /$ dioxane, rt, $1 \mathrm{~h}, 6-58 \%$

\section{Results and Discussion}

A library of $\sim 150,000$ compounds was screened against the LSD1 enzyme in a time-resolved fluorescence resonance energy transfer (TR-FRET) assay at $30 \mu \mathrm{M}$, with an initial hit rate of $0.3 \%$ (as defined by $>70 \%$ inhibition). The resulting 472 compounds were tested for interference of the TRFRET assay and for purity by LC-MS, then taken into 7- and 12- point $\mathrm{IC}_{50}$ testing, yielding 72 hits with $\mathrm{IC}_{50}$ values in the range of $4-102 \mu \mathrm{M}$.

After resynthesis of the original hit matter for validation, we chose to develop a series of sulfonamides that appeared to offer an attractive start-point with multiple vectors for diversification (Figure 2). This series was optimized from compound 10a to give $\mathbf{1 0 b}$ with sub-micromolar activity in the biochemical assay. Both sides of the sulfonamide could be extensively modified while retaining potency; however the aniline portion originating from the HTS could not be improved upon. Unfortunately, when tested in our previously described cellular assay, ${ }^{37} \mathbf{1 0 b}$ and related compounds 
were found to cause no induction of CD86 at $50 \mu \mathrm{M}$ in human THP-1 AML cells (Figure 2B). This disconnect was reinforced when the compounds were tested by surface plasmon resonance (SPR), where the binding response increased linearly with compound concentration (Figure 2C, inset), suggesting that no specific binding between compound and LSD1 protein was occurring. In addition, a competition assay with tranylcypromine demonstrated no abrogation of the interactions of these compounds with LSD1 (data not shown). Several other chemotypes emerging from the HTS were shown to display a similar lack of activity by SPR, suggesting the biochemical assay may be particularly susceptible to false positives, and demonstrating the value of an orthogonal biophysical assay in the screening cascade.
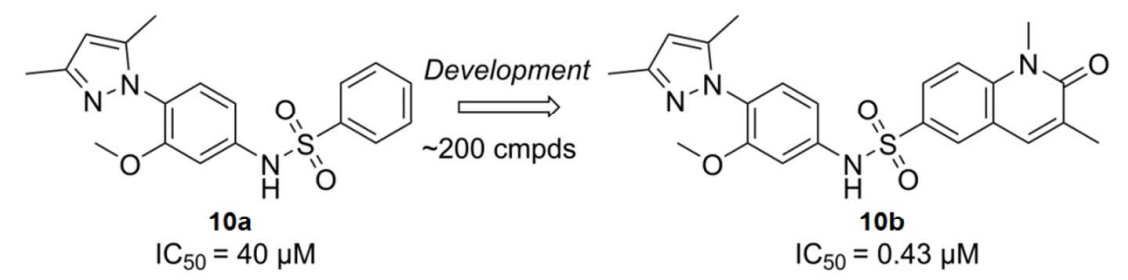

A

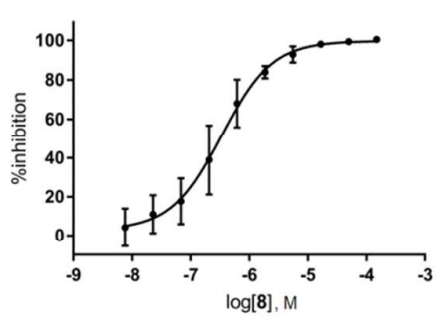

B

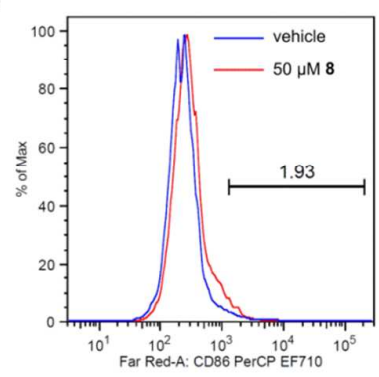

$\mathrm{IC}_{50}=0.43 \mu \mathrm{M}$ $\left.\begin{array}{l}\text { SPR } \\ \text { Cell }\end{array}\right\}$ No activity

C

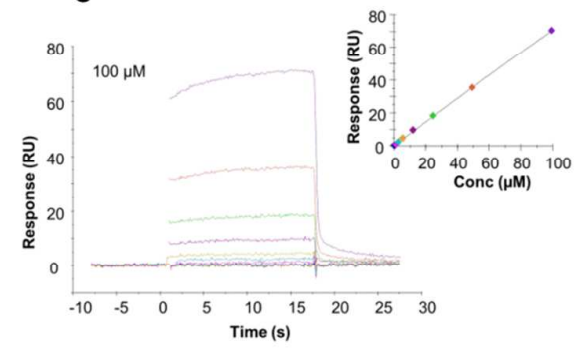

Figure 2. Development and characterization of compound 10b. A: Biochemical assay; B: Surrogate cellular biomarker assay; C: Surface plasmon resonance sensorgram of the interaction between LSD1 and $\mathbf{1 0 b}$ in two-fold dilution series (highest concentration indicated in the graph). 

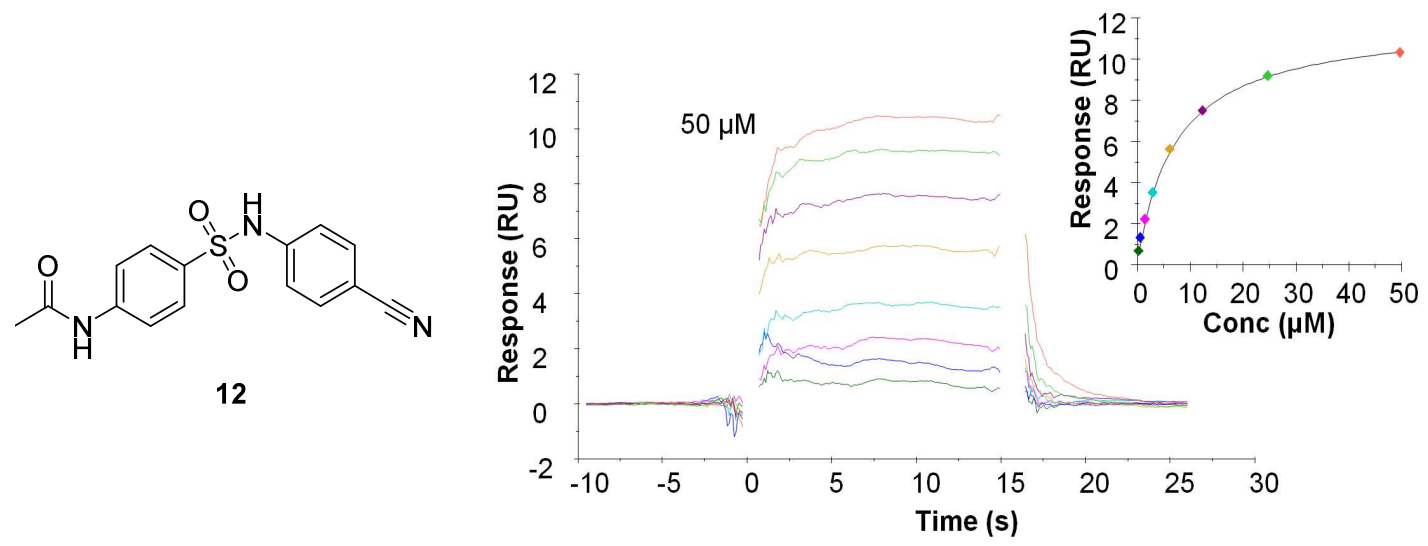

Figure 3. Structure of compound 12 with biochemical and SPR sensorgram indicating the highest tested concentration. $K_{\mathrm{d}}=9.5 \mu \mathrm{M}$. $K_{\mathrm{d}}$ value was determined by SPR at $15{ }^{\circ} \mathrm{C}$ as the average of two experimental series (typically 10 concentrations).

SPR analysis did identify a single compound (12) that displayed reversible binding activity (Figure 3), a sulfonamide that we hypothesized might be acting as a ring-opened isostere of the pyridine scaffold of compound 1. While 1 was disclosed by GSK at the AACR Annual Meeting 2013 (Washington DC, USA), very little work to develop this ligand had been published before $2015 .{ }^{38}$ Certainly, the scope for potential core-hops had been seldom explored at the point at which we began to pursue this approach. To attempt to validate sulfonamides as a potential new scaffold, we used Cresset Spark and Torch software (Welwyn Garden City, U.K.) to align and identify potential new cores by searching fragment libraries for replacements with similar spatial and electronic features. ${ }^{39}$ 

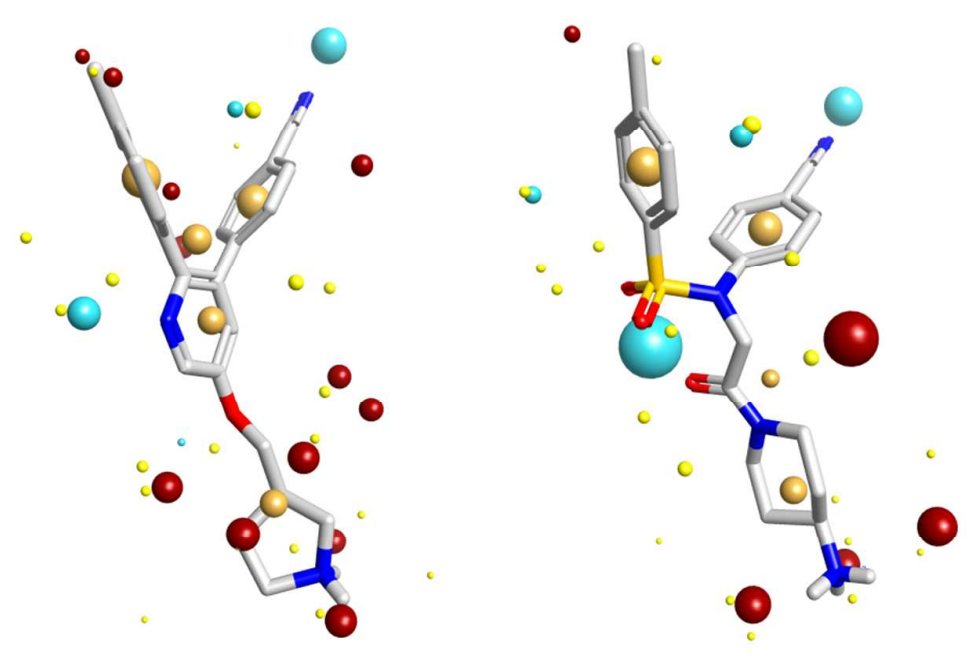

Figure 4. Cresset Torch alignment and structures of compound 1 (left) and 16g (right). Similarity score 0.712 . Blue field points (spheres) highlight energy minima for a positively charged probe, red for a negative probe. Yellow spheres represent an attractive van der Waals minimum for a neutral probe and brown spheres represent hydrophobic regions. Oxygen atoms are shown in red, nitrogen in blue. The similarity score is based on the likeness of the field points in terms of their magnitude and position. A score of greater than 0.7 is considered a 'good' score.

From this output we designed initial targets, a series of sulfonamidoacetamides (Figure 4) that looked to offer ease of synthesis while offering low two-dimensional (2D) similarity in comparison to more recognizable pyridine replacements such as pyridazines or pyrazines. We incorporated the para-cyano and para-tolyl aryl groups from $\mathbf{1}$ for the initial development, focused on optimizing the basic center, by coupling a series of amines to a key sulfonamidoacetic acid intermediate to give compounds $\mathbf{1 6 a -}$ m. (Table 1). In contrast to the sulfonamides $\mathbf{1 0 a}-\mathbf{b}$, these compounds showed specific and reversible binding to LSD1 by SPR, validating them as start points for further assay. Both primary and secondary amides decorated with basic amines were tolerated and displayed significantly improved levels of potency over 16a. Initial optimization gave the 4-aminopiperidine derivative $\mathbf{1 6 g}$. Methylation $\alpha$ - to the basic center (16k) was also tolerated, alongside methylation on the nitrogen itself $(\mathbf{1 6 1}, \mathbf{1 6 m})$, however the activity appeared have reached a plateau, with no compounds achieving a $K_{\mathrm{d}}$ value below $2 \mu \mathrm{M}$. 
Table 1. Optimization of basic center on the acetamidosulfonamide scaffold ${ }^{a}$

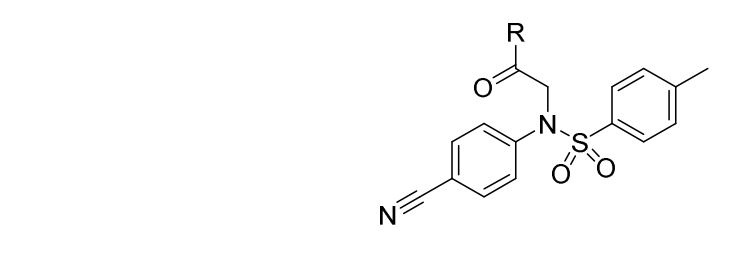

\begin{tabular}{cccc}
\hline Compound & R & IC $_{50}(\boldsymbol{\mu M})$ & SPR $K_{\mathrm{d}}(\boldsymbol{\mu M})$ \\
\hline 1 & - & $0.037(0.012)$ & 0.009
\end{tabular}

16a

*

$16 \mathrm{~b}$

*N." $11.9(0.2)$

$16 \mathrm{c}$<smiles>CNC1C=CNCC1</smiles>

$14.2(0.3)$

3.5

16d

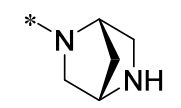

$13.1(0.2)$

$16 \mathrm{e}$

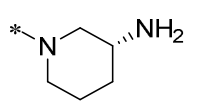

$13.9(0.1)$

4.5

$16 f$<smiles>CN1CCCC(N)C1</smiles>

$24.3(0.4)$

10.3

$16 \mathrm{~g}$<smiles>CN1CCC(N)CC1</smiles>

$7.6(1.2)$

$16 \mathrm{~h}$<smiles>CNC1CCNCC1</smiles>

$15.6(1.3)$

6.5

$16 i$<smiles>CN1CCC(N)C1</smiles>

$22.7(1.6)$

16j<smiles>CN1CC[C@@H](N)C1</smiles>

$16.4(0.6)$

$16 k$

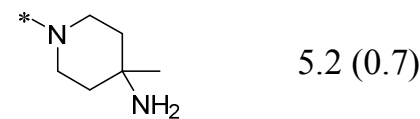



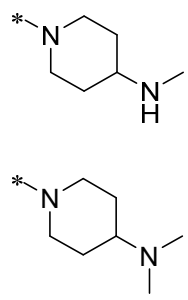

$7.5(1.2)$

2.9

$12.6(1.8)$ 2.9

${ }^{\mathrm{a}} \mathrm{IC}_{50}$ and $K_{\mathrm{d}}$ values for selected compounds against the LSD1 enzyme in biochemical and biophysical assays. Standard deviation is given in parentheses. $\mathrm{IC}_{50}$ determined from 10 point concentration/effect experiments. Geometric mean of at least two independent experimental determinations given. Kd values were determined by SPR at $15{ }^{\circ} \mathrm{C}$ as the average of two experimental series (typically 10 concentrations).

Shortly after synthesizing these initial compounds, a patent from Quanticel disclosed several series of reversible LSD1 inhibitors featuring 6- and 5-membered monocyclic and 6,5-bicyclic core-hops (Figure 1). ${ }^{28}$ Compounds from each series were claimed to display $\mathrm{IC}_{50}$ values against LSD1 of less than $100 \mathrm{nM}$ in biochemical and cellular assays. While the patent reduced the diversity of chemical space available to explore, it also provided useful learning, both in terms of the essential features of the compounds, and which positions are more tolerant to change. For instance, the para-cyanophenyl and the presence of a basic nitrogen center are conserved throughout the examples in the patent, whereas the tolyl moiety was more amenable to optimization, and was successfully replaced with a number of mono- and bicyclic systems (e.g. 3, Figure 1). 
Table 2. Aryl modifications on the acetamidosulfonamide scaffold ${ }^{a}$

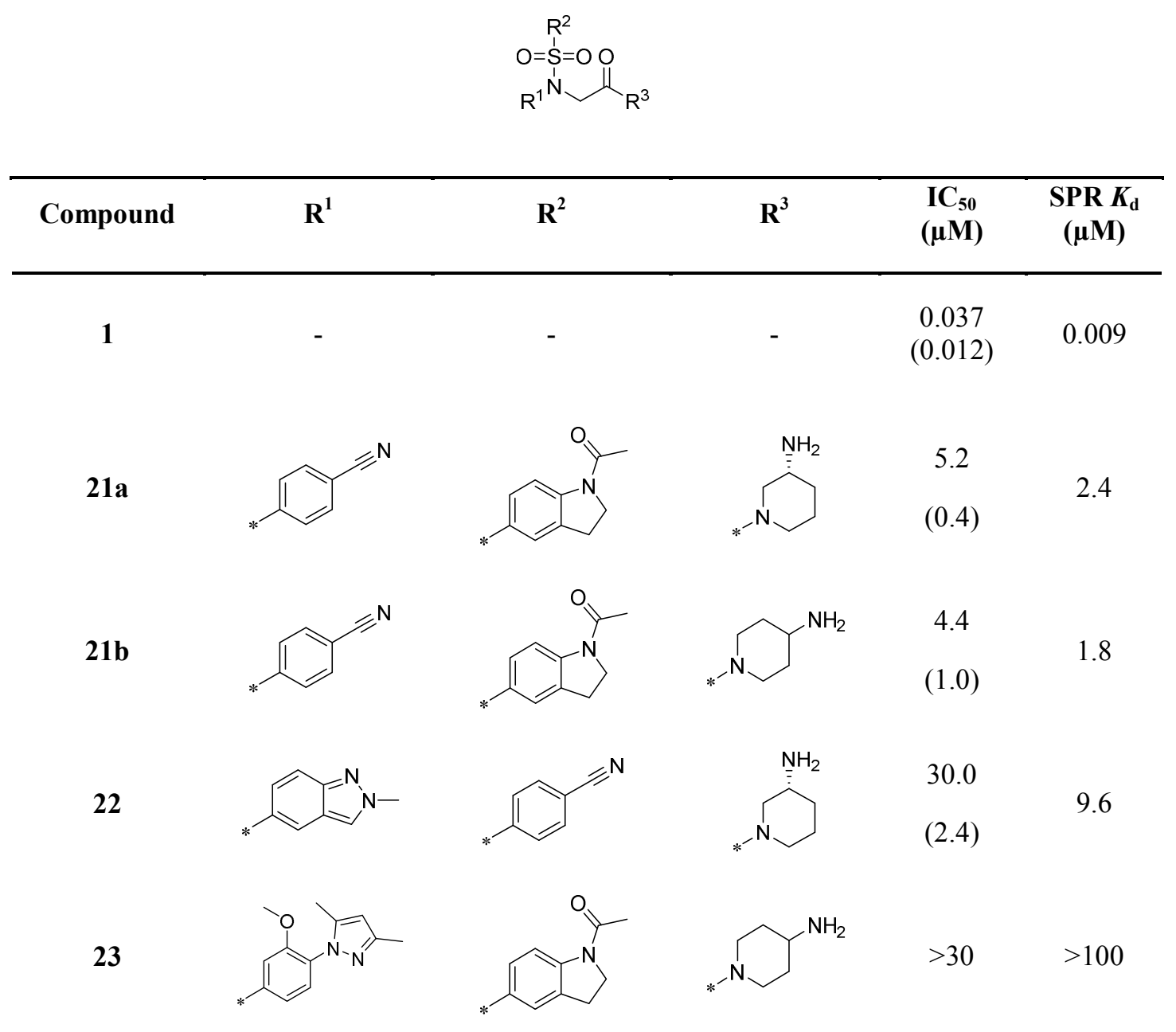

${ }^{\mathrm{a}} \overline{\mathrm{C}_{50} \text { and } K_{\mathrm{d}} \text { values for selected compounds against the LSD1 enzyme in biochemical and biophysical }}$ assays. Standard deviation is given in parentheses. $\mathrm{IC}_{50}$ determined from 10-point concentration/effect experiments. Geometric mean of at least two independent experimental determinations given. $K_{\mathrm{d}}$ values were determined by SPR at $15{ }^{\circ} \mathrm{C}$ as the average of two experimental series (typically 10 concentrations).

With this in mind, we investigated how the modification of the two aryl groups affected the activity (Table 2). Derivatives with an acetylindoline group were shown to give slightly better potency than the parent tolyl (21a-b). On the other hand, compound 22, where the sulfonamide was reversed and 
the tolyl replaced with the favored 2-methylindazole from the Quanticel patent, showed a disappointing drop-off in activity. Adopting the substituted aniline group from the prior HTS series (23) showed no activity by biochemical assay or SPR, while the parent 20 (biochemical $\mathrm{IC}_{50}=1.6$ $\left.\mu \mathrm{M} ; K_{\mathrm{d}}>100 \mu \mathrm{M}\right)$ displayed the same non-specific binding effects by SPR. Despite our optimization attempts, we were disappointed to find that potency could not be significantly improved further, and thus we looked to modify the core itself to establish whether potency could be improved..

Toward this aim, we replaced the $\mathrm{SO}_{2}$ moiety with a methylene linker to give a 4cyanophenylglycinamide core. This alteration has the benefit of a significant reduction in molecular weight and total polar surface area, which could afford increased membrane permeability and bioavailability. However, this modification also introduces an aniline functionality that could potentially be a metabolic liability. ${ }^{40}$ Initially, we chose to adopt the 4-aminopiperidine from compound $\mathbf{1 6 g}$ as the basic center, and focused on modifications of the tolyl- group. Compound 29a demonstrated a 5-fold improvement in potency compared to the matched-pair sulfonamide $\mathbf{1 6 h}$ by both biochemical assay and SPR. In addition, a range of phenyl groups were tolerated and, in one case, improved potency further (29c). These beneficial modifications could be extended to bicyclic systems (15e). We then returned to investigate the basic center and found that homologating the 4aminopiperidine unit to a piperidin-4-ylmethanamine gave a useful $\sim 4$-fold increase in potency (e.g. 29a vs. 30a). Modifying the $\mathrm{pKa}$ of the basic center by introducing of a fluorine atom at the $\beta$-carbon to the amine was deleterious to activity, however decreasing the flexibility of the amine by incorporation into a spirocycle (32) afforded a compound with $<100 \mathrm{nM}$ activity in the biochemical assay. 
Table 3. Aryl optimization on the (4-cyanophenyl)glycine scaffold ${ }^{a}$

29a

${ }^{\mathrm{a}} \mathrm{IC}_{50}$ and $K_{\mathrm{d}}$ values for selected compounds against the LSD1 enzyme in biochemical and biophysical assays. Standard deviation is given in parentheses. $\mathrm{IC}_{50}$ determined from 10 point concentration/effect experiments. Geometric mean of at least two independent experimental determinations given. $\mathrm{Kd}$ values were determined by SPR at $15^{\circ} \mathrm{C}$ as the average of two experimental series (typically 10 concentrations). 
Table 4. Basic center optimization and aryl variation on the (4-cyanophenyl)glycine scaffold ${ }^{a}$<smiles>[R]CN(CC([R])=O)c1ccc(C#N)cc1</smiles>

\begin{tabular}{|c|c|c|c|c|}
\hline Compound & $\mathbf{R}^{1}$ & $\mathbf{R}^{2}$ & $\mathrm{IC}_{50}(\boldsymbol{\mu M})$ & $\begin{array}{c}\operatorname{SPR} K_{\mathrm{d}} \\
(\mu \mathrm{M})\end{array}$ \\
\hline 1 & - & - & $0.037(0.012)$ & 0.009 \\
\hline $30 \mathbf{a}$ & & & $0.29(0.03)$ & 0.11 \\
\hline $30 b$ & & & $0.40(0.11)$ & 0.29 \\
\hline 30c & & & $1.3(0.15)$ & 0.46 \\
\hline 30d & & & $1.0(0.14)$ & 0.42 \\
\hline $30 \mathrm{e}$ & & & $0.83(0.08)$ & 0.49 \\
\hline $30 f$ & & & $0.21(0.06)$ & 0.058 \\
\hline 31 & & & $0.99(0.23)$ & 0.23 \\
\hline 32 & & & $0.083(0.003)$ & 0.032 \\
\hline
\end{tabular}

${ }^{\mathrm{a}} \mathrm{IC}_{50} \overline{\text { and } K_{\mathrm{d}} \text { values for selected compounds against the LSD1 enzyme in biochemical and biophysical }}$ assays. Standard deviation is given in parentheses. $\mathrm{IC}_{50}$ determined from 10 point concentration/effect experiments. Geometric mean of at least two independent experimental determinations given. $K_{\mathrm{d}}$ values were determined by SPR at $15^{\circ} \mathrm{C}$ as the average of two experimental series (typically 10 concentrations). 
In an attempt to rationalize the observed SAR, we performed docking studies, using the previously reported structure of LSD1 bound to tetrahydrofolate (PDB accession code 4KUM). ${ }^{41}$ Protein preparation and docking were performed in Glide (Schrödinger, New York, USA). ${ }^{42}$ The crystal structure of 1 bound to LSD1 has been disclosed, ${ }^{26}$ and from these data, the binding mode of compound 30f was predicted, as displayed in Figure 5. In this predicted pose, the nitrile forms a key hydrogen bonding interaction with K661. The basic center forms a network of ionic interactions with Asp555 and Asp556. This ionic interaction has been exploited previously by Vianello and coworkers. ${ }^{33-34}$ The 3-fluoro-4-methoxyphenyl group sits in a channel formed by Trp695, Ile356, Leu677 and Leu693. The ether oxygen is predicted to make a hydrogen bonding interaction with Gln358, however, if the phenyl group were to flip then it could also potentially form a similar interaction with Asn535. It is worthy of note that a wide variety of scaffold-hops can be tolerated, and this may be explained by a lack of contact between the protein and the scaffold itself, with the key interactions being located at distal ends of the ligands. 

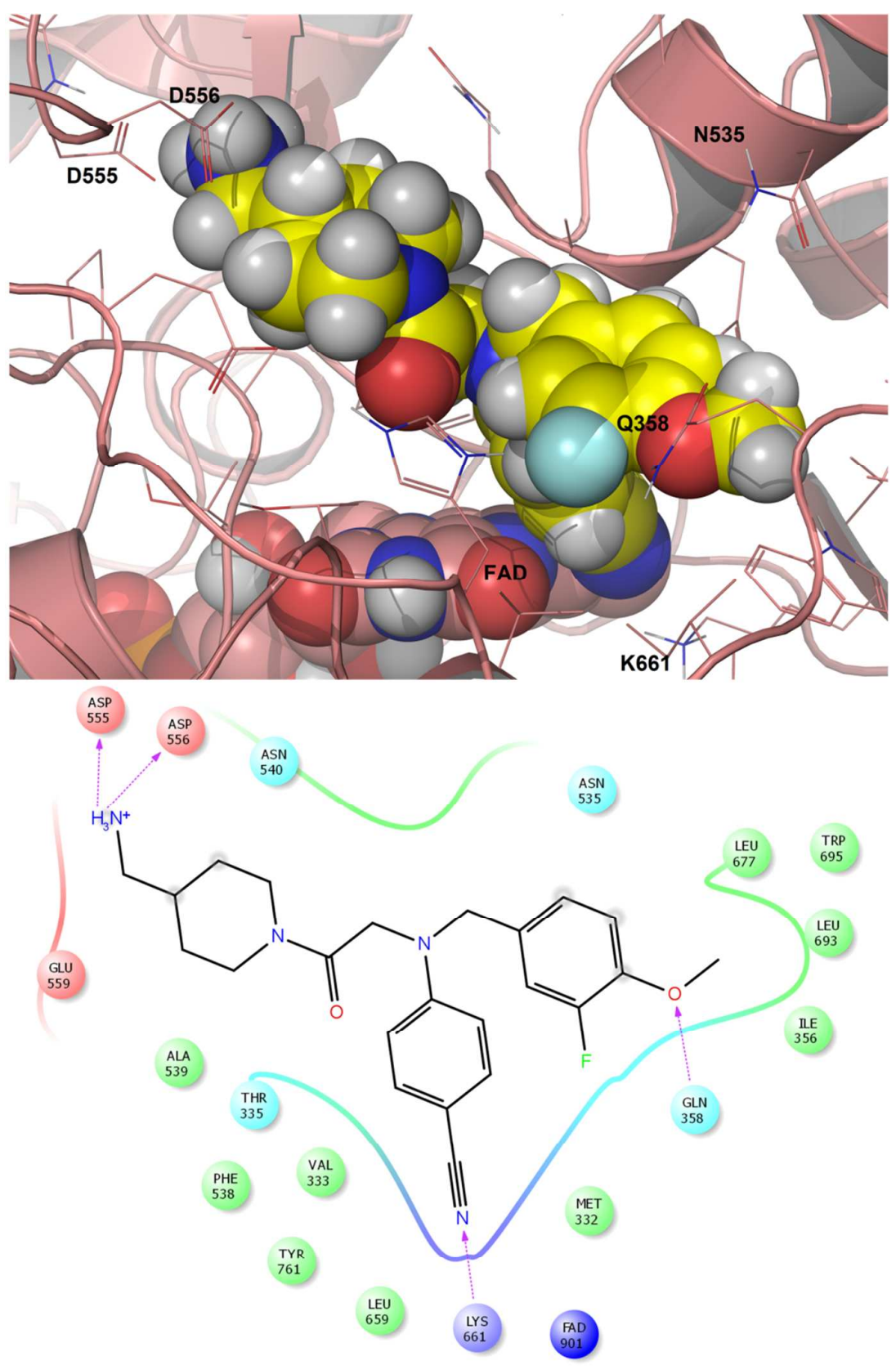

Figure 5. Left: Predicted binding mode of compound $30 f$ in the LSD1 active site (4KUM). Visualized using Maestro. Right: Protein-ligand interaction diagram with key hydrogen bond interactions highlighted (pink arrows). 
To assess the effects of these derivatives on cells, compounds $\mathbf{1}, \mathbf{3 0 f}$ and $\mathbf{3 2}$ were tested at 7 concentrations in the THP-1 AML cell line to measure their effect on expression levels of CD86, a surrogate cellular biomarker of LSD1 inhibition (Figure 6). ${ }^{37}$ Although compound 1 displayed the highest levels of potency in this assay $\left(\mathrm{EC}_{50}=0.30 \mu \mathrm{M}\right)$, we were satisfied to find only a 2-fold drop off in activity to our most active derivative, $32\left(\mathrm{EC}_{50}=0.67 \mu \mathrm{M}\right)$. The less active analogue $30 \mathrm{f}$ displayed more modest activity $\left(\mathrm{EC}_{50}=4.1 \mu \mathrm{M}\right)$, suggesting good correlation between the biochemical and cellular assay.

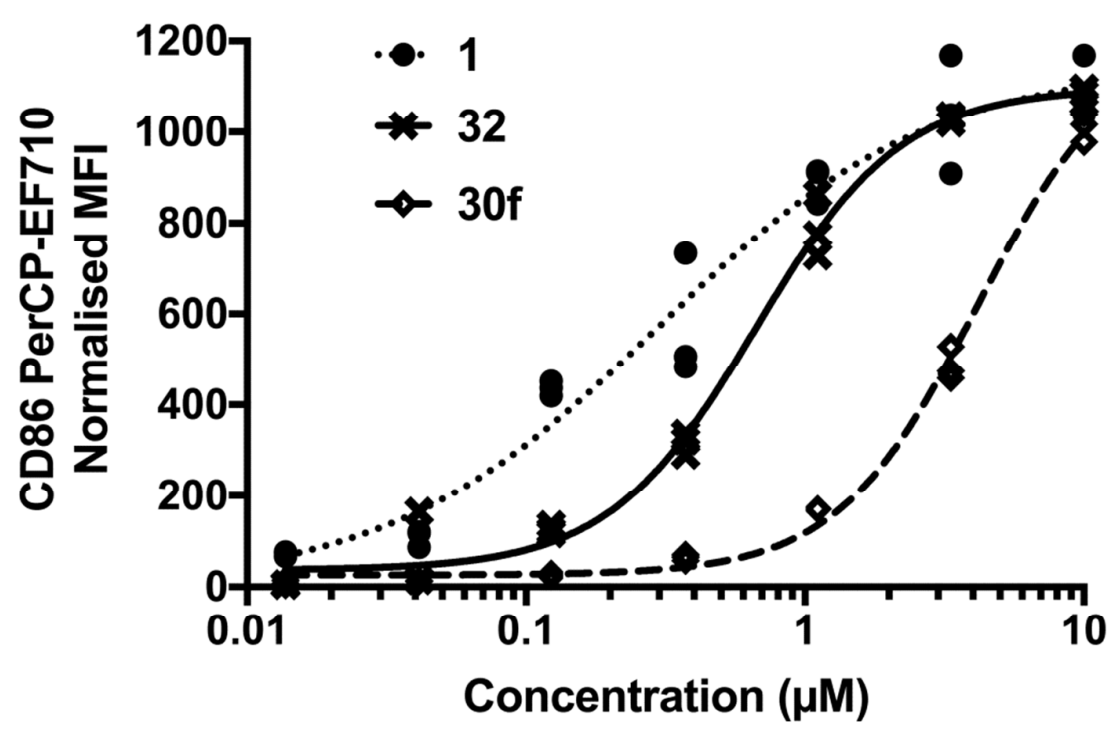

Figure 6. CD86 cell assay results for compounds $\mathbf{1}, \mathbf{3 0 f}$ and $\mathbf{3 2}$.

To further assess cellular effects, we performed colony forming assays using two AML cell lines. This assay format indicates both proliferation of a cell population and the percentage of cells within that population with colony initiating activity. ${ }^{10}$ THP1, and MV4-11 cells were treated with $10 \mu \mathrm{M}$ of $\mathbf{1}$ or 32 for 7 days in semi-solid methylcellulose-based culture. Both compounds substantially reduced both colony forming frequency and the size of the colonies that did develop (Figure 7) indicating significant anti-proliferative activity, in addition to inducing up-regulation of the cellular differentiation marker CD86. To explore whether these compounds induced apoptosis, we performed 
Annexin V-perCP EF710/7AAD staining on THP-1 cells treated for four days with $10 \mu \mathrm{M}$ of each of the compounds. A modest but significant increase in apoptosis was observed (Figure 8). These results, combined with the CD86 data, suggest that compounds such as $\mathbf{3 2}$ act predominantly to promote differentiation of AML cells, with concomitant reduction in clonogenic potential.
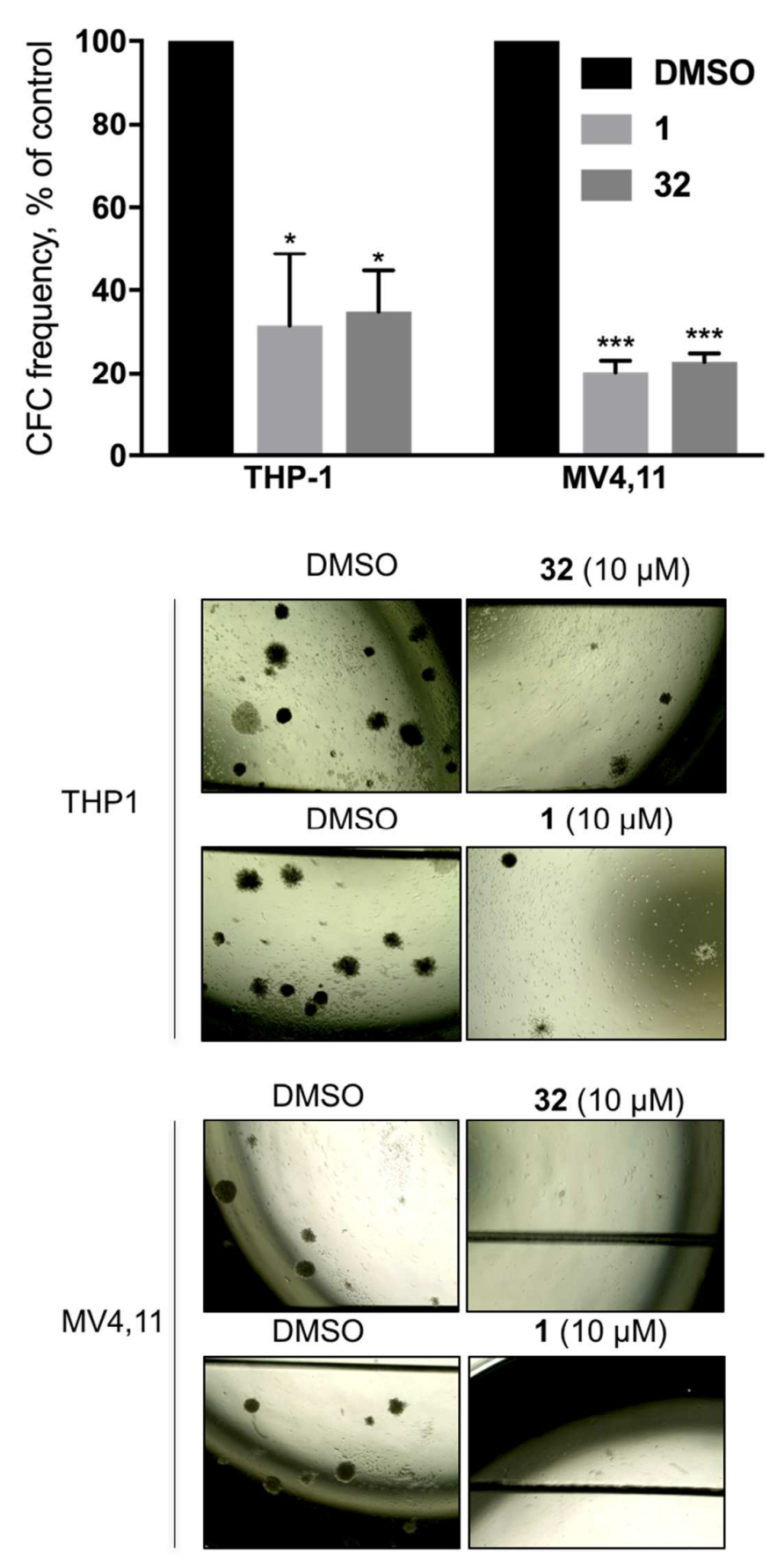
Figure 7. Top: Colony formation assay for THP-1 and MV4-11 cells dosed with $10 \mu \mathrm{M}$ of compounds 1 and 32 for 7 days. $* \mathrm{P}<0.05$, $* * \mathrm{P}<0.01$, ***P $<0.001$, **** $\mathrm{P}<0.0001$, statistical significance calculated using a one-way ANOVA with Dunnett's tests between vehicle treated and compound dosed cells. Bottom: representative images of colonies.

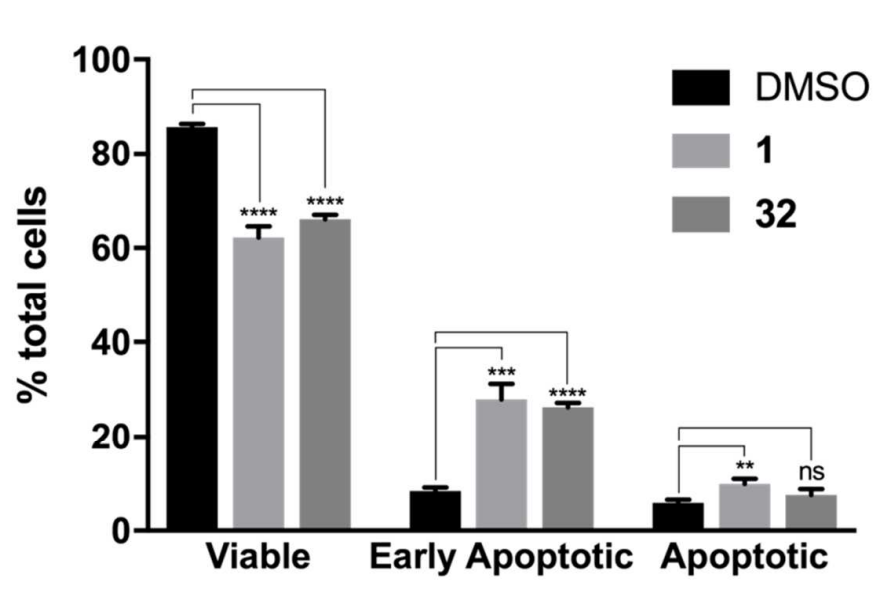

Figure 8. Annexin V-perCP EF710/7AAD double staining experiments results with THP-1 cell dosed with vehicle, or $10 \mu \mathrm{M} 1$ or 32 for 4 days in liquid culture. Early apoptotic cells = Annexin $\mathrm{V}^{\mathrm{pos}} 7$ $\mathrm{AAD}^{\text {neg. }}$; Apoptotic cells $=$ Annexin $\mathrm{V}^{\mathrm{pos}} 7-\mathrm{AAD}^{\mathrm{pos}} . * \mathrm{P}<0.05, * * \mathrm{P}<0.01, * * * \mathrm{P}<0.001, * * * * \mathrm{P}<0.0001$, statistical significance calculated using one-way ANOVA analysis with Dunnett's tests.

in vitro ADME properties

As inhibition of the hERG ion channel proved to be an insurmountable issue in furthering the development of $\mathbf{1}$ towards the clinic, ${ }^{26}$ we were keen to assess our compounds against this target. Compounds 29c, 30f, and 32 were tested in a patch clamp assay, alongside being profiled for their metabolic stability (Table 5). Gratifyingly these compounds displayed improved selectivity against hERG in comparison to $\mathbf{1}\left(\mathrm{IC}_{50}=3.2 \mu \mathrm{M}\right)$, with compound 32 displaying a $\sim 30$-fold window of selectivity between LSD1 inhibition in cells and hERG inhibition. In addition, we observed low levels of clearance in mouse microsomes with all three compounds. Disappointingly, these compounds displayed poor membrane permeability and high levels of efflux in comparison to compound $\mathbf{1}$, which 
could make achieving oral bioavailability challenging, although this liability does not appear to preclude the ability of the compounds to inhibit LSD1 in a cellular context.

Table 5. In vitro parameters for $1,29 \mathrm{c}, 30 \mathrm{f}$ and 32

\begin{tabular}{|c|c|c|c|c|}
\hline & $\mathbf{1}$ & $\mathbf{2 9 c}$ & $\mathbf{3 0 f}$ & $\mathbf{3 2}$ \\
\hline $\begin{array}{c}\text { Caco2 A-B mean } \mathrm{P}_{\text {app }} \\
\left(10^{-6} \mathrm{~cm} / \mathrm{s}\right) ;(\mathrm{efflux} \\
\text { ratio })\end{array}$ & $5.6(3.2)$ & $0.44(48)$ & $0.26(58)$ & $0.09(58)$ \\
\hline $\begin{array}{c}\mathrm{Mo} \mathrm{Mic} \mathrm{CL}_{\text {int }} \\
\left(\mu \mathrm{L} / \mathrm{min} / 10^{6} \text { cells }\right)\end{array}$ & 3.43 & 3.6 & 4.5 & $<1$ \\
\hline $\mathrm{Mo} \mathrm{Mic} \mathrm{T}_{1 / 2}(\mathrm{~min})$ & 404 & 385 & 305 & $>1000$ \\
\hline $\begin{array}{c}\mathrm{hERG} \mathrm{EC}(\mu 0 \mathrm{M}) ; \\
(\text { standard error })\end{array}$ & 3.2 & $>25$ & $12.4(3.4)$ & $20.1(4.6)$ \\
\hline
\end{tabular}

\section{CONCLUSION}

In conclusion, we have developed a series of (4-cyanophenyl)glycine derivatives that show potent activity against LSD1 by both biochemical assay and SPR. Starting from a weakly active HTS hit 12, we identified acyclic lead-like analogues of compound $\mathbf{1}$. We successfully developed these initial start points, leading to the development of compound 32, which potently inhibits LSD1 in biochemical, biophysical and cellular assays. These compounds display much greater levels of selectivity over the hERG cardiac ion channel than compound 1, a liability which precluded further development of that series. Compound $\mathbf{3 2}$ is an attractive tool compound for use in in vitro systems and start-point for future development. More generally, this work suggests the scaffold of compound $\mathbf{1}$ is broadly modifiable, and while the p-cyanophenyl group appears to form a key interaction with K661, modification of the tolyl- functionality and the position and orientation of basic center is much more tolerant to modification.

\section{Experimental Section}

\section{Chemistry}


Flash column chromatography was performed using pre-packed silica gel cartridges (KP-Sil SNAP, Biotage, Hengoed UK or RediSep Rf, Isco). Thin layer chromatography was conducted with $5 \times 10$ $\mathrm{cm}$ plates coated with Merck Type $60 \mathrm{~F}_{254}$ silica gel to a thickness of $0.25 \mathrm{~mm}$. All reagents obtained from commercial sources were used without further purification. Anhydrous solvents were obtained from the Sigma-Aldrich Company Ltd. (Dorset, UK) or Fisher Scientific UK Ltd. (Loughborough, UK), and used without further drying. HPLC grade solvents were obtained from Fisher Chemicals Ltd.

All compounds prepared were $>95 \%$ purity as determined by examination of both the LC-MS and ${ }^{1} \mathrm{H}$ NMR spectra unless otherwise indicated. Where $\mathrm{Cl}$ or $\mathrm{Br}$ were present, expected isotopic distribution patterns were observed.

Proton $\left({ }^{1} \mathrm{H}\right)$ and carbon $\left({ }^{13} \mathrm{C}\right)$ NMR spectra were recorded on a $300 \mathrm{MHz}$ Bruker Avance spectrometer. Solutions were typically prepared in either deuterochloroform $\left(\mathrm{CDCl}_{3}\right)$, deuterated dimethylsulfoxide (DMSO- $d_{6}$ ) or deuterated methanol (methanol- $d_{4}$ ) with chemical shifts referenced to tetramethylsilane (TMS) or deuterated solvent as an internal standard. ${ }^{1} \mathrm{H}$ NMR data are reported indicating the chemical shift $(\delta)$, the integration (e.g. $1 \mathrm{H})$, the multiplicity (s, singlet; $\mathrm{d}$, doublet; $\mathrm{t}$, triplet; q, quartet; m, multiplet; br, broad; dd, doublet of doublets etc.), and the coupling constant $(J)$ in Hz. Deuterated solvents were obtained from Goss Scientific (Crewe, UK). In general, basic N-H protons were not observed.

LC-MS analyses were performed on a Waters (Elstree, UK) Acquity UPLC system fitted with BEH C18 1.7 $\mu \mathrm{M}$ columns $(2.1 \times 50 \mathrm{~mm})$ and with UV diode array detection $(210-400 \mathrm{~nm})$ with a Waters SQD detector. Analyses were performed with either buffered acidic or basic solvents, and using gradients detailed in the Supporting Information.

Some compounds were purified by preparative (prep.) HPLC on a Waters FractionLynx MS autopurification system, with a Waters XBridge $5 \mu \mathrm{m} \mathrm{C18}, 100 \mathrm{~mm} \times 19 \mathrm{~mm}$ i.d. column, running at a flow rate of $20 \mathrm{~mL} / \mathrm{min}$ with UV diode array detection $(210-400 \mathrm{~nm})$ and mass-directed collection using both positive and negative mass ion detection. Purifications were performed using buffered 
acidic or basic solvent systems as appropriate. Compound retention times on the system were routinely assessed using a $30-50 \mu \mathrm{L}$ test injection and a standard gradient, then purified using an appropriately chosen focused gradient as detailed in the Supporting Information, based upon observed retention time.

\section{Preparation of compounds 10a-b}

\section{1-(2-Methoxy-4-nitro-phenyl)-3,5-dimethylpyrazole (8).}

A suspension of 3-methoxy-4-fluoronitrobenzene (25 g, $146 \mathrm{mmol}), 3,5$-dimethylpyrazole (15.5 g, $161 \mathrm{mmol})$ and potassium carbonate $(60.5 \mathrm{~g}, 438 \mathrm{mmol})$ in DMF $(200 \mathrm{~mL})$ was stirred overnight at 80 ${ }^{\circ} \mathrm{C}$. The reaction mixture was added to water $(500 \mathrm{~mL})$ and the resulting yellow precipitate collected by filtration and dried to the title compound (35.8 g, 99\%) as a yellow powder. ${ }^{1} \mathrm{H}$ NMR $(300 \mathrm{MHz}$, Chloroform- $d$ ) $\delta 7.95(\mathrm{dd}, J=8.5,2.4 \mathrm{~Hz}, 1 \mathrm{H}), 7.90(\mathrm{~d}, J=2.4 \mathrm{~Hz}, 1 \mathrm{H}), 7.54(\mathrm{~d}, J=8.5 \mathrm{~Hz}, 1 \mathrm{H})$, $6.03(\mathrm{~s}, 1 \mathrm{H}), 3.94(\mathrm{~s}, 3 \mathrm{H}), 2.31(\mathrm{~s}, 3 \mathrm{H}), 2.14(\mathrm{~s}, 3 \mathrm{H})$. LC-MS: (High pH) $\mathrm{t}_{\mathrm{R}} 1.09 \mathrm{~min}, \mathrm{~m} / z 248.1$ $[\mathrm{M}+\mathrm{H}]^{+}, 100 \%$ purity.

\section{4-(3,5-Dimethylpyrazol-1-yl)-3-methoxyaniline (9).}

A stirred suspension of 1-(2-methoxy-4-nitro-phenyl)-3,5-dimethylpyrazole (36 g, $0.145 \mathrm{~mol})$, zinc powder $(28.6 \mathrm{~g}, 0.44 \mathrm{~mol})$ and ammonium formate $(91.2 \mathrm{~g}, 1.46 \mathrm{~mol})$ in methanol $(250 \mathrm{~mL})$ was heated overnight to $40{ }^{\circ} \mathrm{C}$. The reaction mixture was passed through a hydrophobic frit and concentrated to dryness. The resulting residue was suspended between brine $(250 \mathrm{~mL})$ and DCM (500 $\mathrm{mL}$ ), the organic layer passed through a hydrophobic frit and concentrated to dryness to afford the crude product. Recrystallization from hexanes afforded the title compound $(24.7 \mathrm{~g}, 78 \%)$ as off-white

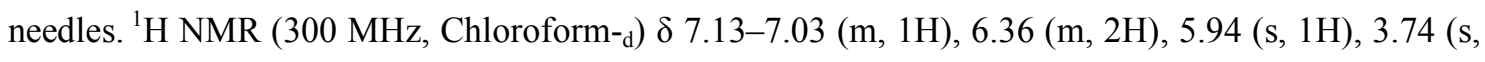
$3 \mathrm{H}), 2.30(\mathrm{~s}, 3 \mathrm{H}), 2.08(\mathrm{~s}, 3 \mathrm{H})$. LC-MS: (High pH) t $0.88 \mathrm{~min}, \mathrm{~m} / \mathrm{z} 218.2[\mathrm{M}+\mathrm{H}]^{+}, 98 \%$ purity.

\section{$N$-[4-(3,5-Dimethylpyrazol-1-yl)-3-methoxyphenyl]benzenesulfonamide (10a).}

A solution of benzenesulfonyl chloride $(18 \mu \mathrm{L}, 0.14 \mathrm{mmol})$ and 4-(3,5-dimethylpyrazol-1-yl)-3methoxy-aniline $(30 \mathrm{mg}, 0.14 \mathrm{mmol})$ in pyridine $(0.45 \mathrm{~mL})$ was stirred at $100{ }^{\circ} \mathrm{C}$ for 1 hour. The 
reaction was concentrated to dryness then purified by preparative HPLC (low $\mathrm{pH}$ gradient 3 ) to afford the title compound (20 mg, 41\%) as a white powder. ${ }^{1} \mathrm{H}$ NMR $\left(300 \mathrm{MHz}, \mathrm{DMSO}-d_{6}\right) \delta 8.39(\mathrm{~s}, 1 \mathrm{H})$, 7.90-7.75 (m, 2H), 7.65-7.42 (m, 3H), $7.02(\mathrm{~d}, J=8.4 \mathrm{~Hz}, 1 \mathrm{H}), 6.83(\mathrm{~d}, J=2.2 \mathrm{~Hz}, 1 \mathrm{H}), 6.67$ (dd, $J$ $=8.4,2.2 \mathrm{~Hz}, 1 \mathrm{H}), 5.94-5.81(\mathrm{~m}, 1 \mathrm{H}), 3.62(\mathrm{~s}, 3 \mathrm{H}), 2.09(\mathrm{~s}, 3 \mathrm{H}), 1.91(\mathrm{~s}, 3 \mathrm{H})$.

\section{$N$-[4-(3,5-Dimethylpyrazol-1-yl)-3-methoxyphenyl]-1,3-dimethyl-2-oxo-quinoline-6-sulfonamide} (10b).

A solution of 4-(3,5-dimethylpyrazol-1-yl)-3-methoxyaniline $(28 \mathrm{mg}, 0.13 \mathrm{mmol})$ and 1,3-dimethyl-2oxo-quinoline-6-sulfonyl chloride $(34 \mathrm{mg}, 0.12 \mathrm{mmol})$ in pyridine $(300 \mu \mathrm{L})$ was stirred at room temperature overnight. The reaction mixture was diluted with 2:1:1 (v:v:v) DMSO:water:MeCN (700 $\mu \mathrm{L}$ ), then purified by preparative HPLC (low $\mathrm{pH}$ ) to afford the title compound (39 $\mathrm{mg}, 70 \%$ ) as a white powder. ${ }^{1} \mathrm{H}$ NMR (300 MHz, DMSO- $\left.d_{6}\right) \delta 10.62(\mathrm{~s}, 1 \mathrm{H}), 8.15$ (d, $\left.J=2.2 \mathrm{~Hz}, 1 \mathrm{H}\right), 7.97-7.86$ (m, 2H), $7.67(\mathrm{~d}, J=9.0 \mathrm{~Hz}, 1 \mathrm{H}), 7.08(\mathrm{~d}, J=8.4 \mathrm{~Hz}, 1 \mathrm{H}), 6.93(\mathrm{~d}, J=2.2 \mathrm{~Hz}, 1 \mathrm{H}), 6.75$ (dd, $J=8.4$, $2.2 \mathrm{~Hz}, 1 \mathrm{H}), 5.90(\mathrm{~s}, 1 \mathrm{H}), 3.66(\mathrm{~s}, 3 \mathrm{H}), 3.64(\mathrm{~s}, 3 \mathrm{H}), 2.12(\mathrm{~s}, 3 \mathrm{H}), 2.07(\mathrm{~s}, 3 \mathrm{H}), 1.91(\mathrm{~s}, 3 \mathrm{H}) .{ }^{13} \mathrm{C} \mathrm{NMR}$ $\left(75 \mathrm{MHz}\right.$, Methanol- $\left.d_{4}\right) \delta 144.1,140.5,137.6,135.1,133.2,130.5,128.7,124.8,122.1,114.7,114.0$, 110.8, 106.8, 57.4, 30.9, 22.4, 15.7, 15.2. HRMS (ESI) $m / z[M-H]^{-}$calcd for $\mathrm{C}_{23} \mathrm{H}_{23} \mathrm{~N}_{4} \mathrm{O}_{4} \mathrm{~S}: 451.1445$. Found: 451.1443 .

\section{Preparation of compound 12}

\section{$N$-[4-[(4-Cyanophenyl)sulfamoyl]phenyl]acetamide (12).}

A solution of DMAP (50 mg, 0.42mmol), $p$-cyanoaniline $(50 \mathrm{mg}, 0.42 \mathrm{mmol})$ and 4acetamidobenzenesulfonyl chloride $(99 \mathrm{mg}, 0.42 \mathrm{mmol})$ in acetonitrile $(5 \mathrm{~mL})$ was heated by microwave irradiation to $100{ }^{\circ} \mathrm{C}$ for $1 \mathrm{~h}$. The reaction was concentrated to dryness then purified by preparative HPLC (low pH gradient 2) to afford the title compound (49 $\mathrm{mg}, 37 \%$ ) as colourless crystals. ${ }^{1} \mathrm{H}$ NMR $\left(300 \mathrm{MHz}, \mathrm{DMSO}-d_{6}\right) \delta 10.95(\mathrm{~s}, 1 \mathrm{H}), 10.34(\mathrm{~s}, 1 \mathrm{H}), 7.83-7.62(\mathrm{~m}, 6 \mathrm{H}), 7.28-7.15$ (m, 2H), 2.06 (s, 3H).

\section{Preparation of compounds $16 a-16 m$}




\section{$N$-(4-Cyanophenyl)-4-methylbenzenesulfonamide (13).}

To a stirred solution of 4-cyanoaniline $(5 \mathrm{~g}, 42.3 \mathrm{mmol})$ in pyridine $(3.6 \mathrm{~mL})$ and acetonitrile $(9 \mathrm{~mL})$ was added portionwise $p$-toluenesulfonyl chloride $(8.88 \mathrm{~g}, 46.6 \mathrm{mmol})$. The reaction mixture was stirred at room temperature overnight, then water $(50 \mathrm{~mL})$ was added and the resulting light orange precipitate collected by filtration, washed with water $(3 \times 20 \mathrm{~mL})$ and dried under vacuum at $50{ }^{\circ} \mathrm{C}$ to afford the title compound (8.92 g, 77\%) as a light orange powder. ${ }^{1} \mathrm{H}$ NMR (300 MHz, DMSO- $\left.d_{6}\right) \delta$ 10.99 (s, 1H), 7.78-7.61 (m, 4H), 7.43-7.33 (m, 2H), 7.32-7.15 (m, 2H), 2.34 (s, 3H). LC-MS: (High pH) $\mathrm{t}_{\mathrm{R}} 0.82 \mathrm{~min}, \mathrm{~m} / \mathrm{z} 271.1[\mathrm{M}-\mathrm{H}]^{-}, 100 \%$ purity.

tert-Butyl 2-[4-cyano- $N$-(p-tolylsulfonyl)anilino]acetate (14).

To a stirred suspension of N-(4-cyanophenyl)-4-methylbenzenesulfonamide (2 g, $7.34 \mathrm{mmol})$ and potassium carbonate $(2.02 \mathrm{~g}, 14.7 \mathrm{mmol})$ in DMF $(20 \mathrm{~mL})$ was added tert-butyl bromoacetate $(1.30$ $\mathrm{mL}, 8.81 \mathrm{mmol}$ ) and the reaction mixture heated to $80^{\circ} \mathrm{C}$ for $1 \mathrm{~h}$. The reaction mixture was diluted with water $(50 \mathrm{~mL})$ then extracted with DCM $(2 \times 20 \mathrm{~mL})$. The combined organic layers were passed through a hydrophobic frit and concentrated to dryness to afford the title compound $(2.71 \mathrm{~g}, 97 \%)$ as an orange oil. ${ }^{1} \mathrm{H}$ NMR $(300 \mathrm{MHz}$, Chloroform- $d$ ) $\delta$ 7.66-7.51 (m, 4H), 7.41-7.23 (m, 4H), 4.35 (s, 2H), $2.43(\mathrm{~s}, 3 \mathrm{H}), 1.40(\mathrm{~s}, 9 \mathrm{H})$. LC-MS: (High pH) te $1.32 \mathrm{~min}, \mathrm{~m} / \mathrm{z} 387.1[\mathrm{M}+\mathrm{H}]^{+}, 94 \%$ purity.

\section{2-[4-Cyano-N-(p-tolylsulfonyl)anilino]acetic acid (15).}

A stirred solution of tert-butyl 2-[4-cyano-N-( $p$-tolylsulfonyl)anilino]acetate $(2.9 \mathrm{~g}, 7.5 \mathrm{mmol})$ in trifluoroacetic acid $(2.79 \mathrm{~mL}, 37.5 \mathrm{mmol})$ and DCM $(30 \mathrm{~mL})$ was heated to $30{ }^{\circ} \mathrm{C}$ for $1 \mathrm{~h}$. The reaction mixture was concentrated to dryness to afford an orange oil. Purification by column chromatography (0 to $60 \%$ EtOAc in isohexane, then $10 \% \mathrm{MeOH}$ in $\mathrm{DCM}$ ) afforded the title compound as a colourless oil that solidified upon standing to give colourless crystals. ${ }^{1} \mathrm{H}$ NMR (300 MHz, DMSO-d $\left.d_{6}\right) \delta 13.06(\mathrm{~s}, 1 \mathrm{H}), 7.87-7.75(\mathrm{~m}, 2 \mathrm{H}), 7.65-7.53(\mathrm{~m}, 2 \mathrm{H}), 7.39(\mathrm{~m}, 4 \mathrm{H}), 4.55(\mathrm{~s}, 2 \mathrm{H})$, 2.38 (s, 3H). LC-MS: (High pH) $\mathrm{t}_{\mathrm{R}} 0.63 \mathrm{~min}, \mathrm{~m} / \mathrm{z} 319.1[\mathrm{M}-\mathrm{H}]^{-}, 96 \%$ purity. 
General method A: To a stirred solution of 2-[4-cyano- $N$-(p-tolylsulfonyl)anilino]acetic acid (30. $\mathrm{mg}, 0.09 \mathrm{mmol})$, the appropriate bis-amine (1.2 eq.) and N,N-Diisopropylethylamine (45 $\mu \mathrm{L}, 0.27$ mmol) in DMF $(300 \mu \mathrm{L})$ was added COMU $(58 \mathrm{mg}, 0.14 \mathrm{mmol})$ and the reaction mixture stirred at room temperature for $6 \mathrm{~h}$. The reaction mixture was concentrated to dryness and purified by mass directed preparative HPLC (high $\mathrm{pH}$ ), to afford the desired product.

General method B: To a stirred solution of 2-[4-cyano- $N$-(p-tolylsulfonyl)anilino]acetic acid (30 mg, $0.09 \mathrm{mmol}$ ), the appropriate Boc-protected bis-amine (1.2 eq.) and $\mathrm{N}, \mathrm{N}$-diisopropylethylamine (45 $\mu \mathrm{L}, 0.27 \mathrm{mmol})$ in DMF $(300 \mu \mathrm{L})$ was added COMU $(58 \mathrm{mg}, 0.14 \mathrm{mmol})$ and the reaction mixture stirred at room temperature for $6 \mathrm{~h}$. The reaction mixture was concentrated to dryness and $4 \mathrm{M} \mathrm{HCl}$ in dioxane $(1 \mathrm{~mL})$ was added. This was stirred for $1 \mathrm{~h}$, then concentrated to dryness and purified by mass directed preparative HPLC (high $\mathrm{pH}$ ), to afford the desired product.

\section{2-[4-Cyano- $N$-(p-tolylsulfonyl)anilino]- $N$-(3-pyridyl)acetamide (16a).}

Prepared by general method A using 3-aminopyridine to afford the title compound ( $24 \mathrm{mg}, 65 \%)$ as a light brown powder. ${ }^{1} \mathrm{H}$ NMR $\left(300 \mathrm{MHz}\right.$, Methanol- $\left.d_{4}\right) \delta 8.68(\mathrm{dd}, J=2.6,0.8 \mathrm{~Hz}, 1 \mathrm{H}), 8.27(\mathrm{dd}, J=$ 4.8, $1.5 \mathrm{~Hz}, 1 \mathrm{H}), 8.07$ (ddd, $J=8.4,2.6,1.5 \mathrm{~Hz}, 1 \mathrm{H}), 7.72-7.65(\mathrm{~m}, 2 \mathrm{H}), 7.63-7.57(\mathrm{~m}, 2 \mathrm{H}), 7.54-$ $7.43(\mathrm{~m}, 2 \mathrm{H}), 7.44-7.28(\mathrm{~m}, 3 \mathrm{H}), 4.61(\mathrm{~s}, 2 \mathrm{H}), 2.42(\mathrm{~s}, 3 \mathrm{H})$.

\section{2-[4-Cyano- $N$-(p-tolylsulfonyl)anilino]- $N$-[(3R)-quinuclidin-3-yl] acetamide (16b).}

Prepared by general method A using $(R)$-3-aminoquinuclidine dihydrochloride to afford the title product as an orange oil $(14 \mathrm{mg}, 35 \%) .{ }^{1} \mathrm{H}$ NMR $\left(300 \mathrm{MHz}\right.$, Methanol- $\left.d_{4}\right) \delta 8.49(\mathrm{~s}, 1 \mathrm{H}), 7.75-7.63$ (m, 2H), 7.60-7.50 (m, 2H), 7.42 (m, 2H), 7.40-7.34 (m, 2H), $4.42(\mathrm{~s}, 2 \mathrm{H}), 4.17(\mathrm{~m}, 1 \mathrm{H}), 3.74-3.60$ (m, 1H), 3.34-3.19 (m, 4H), $3.02(\mathrm{dd}, J=13.8,4.7 \mathrm{~Hz}, 1 \mathrm{H}), 2.44(\mathrm{~s}, 3 \mathrm{H}), 2.12(\mathrm{q}, J=3.1 \mathrm{~Hz}, 1 \mathrm{H})$, $1.99(\mathrm{~s}, 3 \mathrm{H}), 1.86(\mathrm{~s}, 1 \mathrm{H})$.

\section{2-[4-Cyano- $N$-(p-tolylsulfonyl)anilino]- $N$-[(3S)-quinuclidin-3-yl]acetamide (16c).}

Prepared by general method A using (S)-3-aminoquinuclidine dihydrochloride to afford the title product as a yellow powder $(11 \mathrm{mg}, 28 \%) .{ }^{1} \mathrm{H}$ NMR $\left(300 \mathrm{MHz}\right.$, Methanol- $\left.d_{4}\right) \delta 8.46(\mathrm{~s}, 1 \mathrm{H}), 7.70(\mathrm{dd}$, 
$J=1.9,8.7 \mathrm{~Hz}, 2 \mathrm{H}), 7.60-7.50(\mathrm{~m}, 2 \mathrm{H}), 7.47-7.40(\mathrm{~m}, 2 \mathrm{H}), 7.37$ (d, $J=7.9 \mathrm{~Hz}, 2 \mathrm{H}), 4.43(\mathrm{~s}, 2 \mathrm{H})$, 4.19 (m, 1H), 3.72-3.62 (m, 1H), 3.29-3.22 (m, 3H), 3.04 (dd, J = 13.8, $4.7 \mathrm{~Hz}, 1 \mathrm{H}), 2.44(\mathrm{~s}, 3 \mathrm{H})$, $2.13(\mathrm{~m}, 1 \mathrm{H}), 2.06-1.97(\mathrm{~m}, 4 \mathrm{H}), 1.87(\mathrm{~s}, 1 \mathrm{H})$.

\section{$N$-(4-Cyanophenyl)- $N$-[2-[(1S,4S)-2,5-diazabicyclo[2.2.1] heptan-2-yl]-2-oxo-ethyl]-4-methyl-} benzenesulfonamide (16d).

Prepared by general method B using (1S,4S)-2-Boc-2,5-diazabicyclo[2.2.1]heptane to afford the title compound (28 mg, 75\%) as a white powder. ${ }^{1} \mathrm{H}$ NMR (300 MHz, Methanol- $\left.d_{4}\right) \delta 8.50(\mathrm{~s}, 1 \mathrm{H}), 7.78-$ 7.60 (m, 2H), 7.64-7.47 (m, 2H), 7.50-7.25 (m, 4H), 4.43 (s, 2H), 4.18 (ddd, $J=8.3,5.3,3.3 \mathrm{~Hz}$, 1H), 3.74-3.59 (m, 1H), 3.34-3.15 (m, 4H), 3.02 (ddd, $J=13.5,5.3,2.2 \mathrm{~Hz}, 1 \mathrm{H}), 2.43$ (s, 3H), $2.18-$ $1.90(\mathrm{~m}, 2 \mathrm{H}), 1.88-1.76(\mathrm{~m}, 1 \mathrm{H})$

$N$-[2-[(3R)-3-Amino-1-piperidyl]-2-oxo-ethyl]-N-(4-cyanophenyl)-4-methyl-benzenesulfonamide (16e).

Prepared by general method B using $(R)$-3-Boc-aminopiperidine to afford the title compound (14 mg, $37 \%$ ) as a white powder. ${ }^{1} \mathrm{H}$ NMR (300 MHz, DMSO- $\left.d_{6}\right) \delta 6.85-6.78(\mathrm{~m}, 2 \mathrm{H}), 6.78-6.68(\mathrm{~m}, 2 \mathrm{H})$, 6.60-6.53 (m, 2H), $6.51(\mathrm{~d}, J=8.1 \mathrm{~Hz}, 2 \mathrm{H}), 3.89(\mathrm{~d}, J=16.5 \mathrm{~Hz}, 1 \mathrm{H}), 3.81(\mathrm{~d}, J=16.5 \mathrm{~Hz}, 1 \mathrm{H}), 3.38$ (d, $J=12.5 \mathrm{~Hz}, 1 \mathrm{H}), 3.29-3.08(\mathrm{~m}, 1 \mathrm{H}), 2.96(\mathrm{~d}, J=13.7 \mathrm{~Hz}, 1 \mathrm{H}), 2.61-2.06(\mathrm{~m}, 3 \mathrm{H}), 1.58(\mathrm{~s}, 3 \mathrm{H})$, $1.08-1.00(\mathrm{~m}, 1 \mathrm{H}), 0.92-0.78(\mathrm{~m}, 2 \mathrm{H})$.

\section{$N$-[2-[(3S)-3-Amino-1-piperidyl]-2-oxo-ethyl]- $N$-(4-cyanophenyl)-4-methyl-benzenesulfonamide} (16f).

Prepared by general method B using (S)-3-Boc-aminopiperidine to afford the title compound (18 mg, $48 \%$ ) as a white powder. ${ }^{1} \mathrm{H}$ NMR (300 MHz, DMSO- $\left.d_{6}\right) \delta 7.81-7.74(\mathrm{~m}, 2 \mathrm{H}), 7.72-7.60(\mathrm{~m}, 2 \mathrm{H})$, 7.43-7.27 (m, 4H), $4.85(\mathrm{~d}, J=17.3 \mathrm{~Hz}, 1 \mathrm{H}), 4.70(\mathrm{~d}, J=17.3 \mathrm{~Hz}, 1 \mathrm{H}), 4.16-4.04(\mathrm{~m}, 1 \mathrm{H}), 3.71(\mathrm{~d}, J$ $=12.5 \mathrm{~Hz}, 2 \mathrm{H}), 3.10-2.86(\mathrm{~m}, 1 \mathrm{H}), 2.86(\mathrm{~s}, 1 \mathrm{H}), 2.73-2.51(\mathrm{~m}, 1 \mathrm{H}), 2.38(\mathrm{~s}, 3 \mathrm{H}), 1.95-1.12(\mathrm{~m}, 4 \mathrm{H})$.

\section{$N$-[2-(4-Amino-1-piperidyl)-2-oxo-ethyl]- $N$-(4-cyanophenyl)-4-methyl-benzenesulfonamide} (16g). 
Prepared by general method B using 4-[(tert-Butoxycarbonyl)amino]piperidine to afford the title compound (21 mg, 56\%) as a white powder. ${ }^{1} \mathrm{H}$ NMR (300 MHz, DMSO- $\left.d_{6}\right) \delta 7.87-7.69(\mathrm{~m}, 2 \mathrm{H})$, 7.74-7.59 (m, 2H), 7.43-7.30 (m, 4H), 4.85 (d, $J=17.3 \mathrm{~Hz}, 1 \mathrm{H}), 4.70(\mathrm{~d}, J=17.3 \mathrm{~Hz}, 1 \mathrm{H}), 4.18(\mathrm{~d}, J$ $=13.7 \mathrm{~Hz}, 1 \mathrm{H}), 3.88(\mathrm{~d}, J=13.7 \mathrm{~Hz}, 1 \mathrm{H}), 3.09(\mathrm{~m}, 2 \mathrm{H}), 2.73-2.53(\mathrm{~m}, 1 \mathrm{H}), 2.38(\mathrm{~s}, 3 \mathrm{H}), 1.85(\mathrm{~m}$, 2H), $1.50-1.30(\mathrm{~m}, 1 \mathrm{H}), 1.31-1.07(\mathrm{~m}, 1 \mathrm{H})$.

2-[4-Cyano- $N$-(p-tolylsulfonyl)anilino]- $N$-(4-piperidyl)acetamide (16h).

Prepared by general method B using 4-amino-1-Boc-piperidine to afford the title compound (19 mg, $51 \%$ ) as a white powder. ${ }^{1} \mathrm{H}$ NMR (300 MHz, DMSO- $\left.d_{6}\right) \delta 8.15(\mathrm{~d}, J=7.6 \mathrm{~Hz}, 1 \mathrm{H}), 7.90-7.71(\mathrm{~m}$, 2H), 7.62-7.50 (m, 2H), 7.48-7.30 (m, 4H), $4.33(\mathrm{~s}, 2 \mathrm{H}), 3.70-3.53(\mathrm{~m}, 2 \mathrm{H}), 3.11-2.97(\mathrm{~m}, 2 \mathrm{H})$, 2.75-2.61 (m, 2H), 2.39 (s, 3H), 1.72-1.59 (m, 2H), 1.45-1.27 (m, 2H).

$N$-[2-[(3S)-3-Aminopyrrolidin-1-yl]-2-oxo-ethyl]- $N$-(4-cyanophenyl)-4-methylbenzenesulfonamide (16i).

Prepared by general method B using (S)-3-(Boc-amino)pyrrolidine to afford the title compound (18 $\mathrm{mg}, 50 \%)$ as a white powder. ${ }^{1} \mathrm{H}$ NMR $\left(300 \mathrm{MHz}, \mathrm{DMSO}-d_{6}\right) \delta 7.84-7.72(\mathrm{~m}, 2 \mathrm{H}), 7.66(\mathrm{dq}, J=8.6$, $2.2 \mathrm{~Hz}, 2 \mathrm{H}), 7.50-7.27$ (m, 5H), $4.65(\mathrm{~s}, 1 \mathrm{H}), 4.61$ (s, 1H), 3.69-3.48 (m, 1H), 3.47-3.07 (m, 3H), $2.38(\mathrm{~s}, 3 \mathrm{H}), 2.13-1.85(\mathrm{~m}, 1 \mathrm{H}), 1.85-1.52(\mathrm{~m}, 1 \mathrm{H})$.

\section{$N$-[2-[(3R)-3-Aminopyrrolidin-1-yl]-2-oxo-ethyl]- $N$-(4-cyanophenyl)-4-methyl- benzenesulfonamide (16j).}

Prepared by general method B using (R)-3-(Boc-amino)pyrrolidine to afford the title compound (23 $\mathrm{mg}, 64 \%)$ as a white powder. ${ }^{1} \mathrm{H}$ NMR $\left(300 \mathrm{MHz}, \mathrm{DMSO}-d_{6}\right) \delta 7.84-7.72(\mathrm{~m}, 2 \mathrm{H}), 7.72-7.58(\mathrm{~m}$, 2H), 7.42-7.34 (m, 4H), 4.75-4.55 (m, 2H), 3.69-3.56 (m, 1H), 3.62-3.21 (m, 3H), $3.16(\mathrm{~m}, 1 \mathrm{H})$, $2.38(\mathrm{~s}, 3 \mathrm{H}), 2.13-1.85(\mathrm{~m}, 1 \mathrm{H}), 1.85-1.51(\mathrm{~m}, 1 \mathrm{H})$.

$N$-[2-(4-Amino-4-methyl-1-piperidyl)-2-oxo-ethyl]- $N$-(4-cyanophenyl)-4-methylbenzenesulfonamide (16k). 
Prepared by general method B using tert-butyl N-(4-methyl-4-piperidyl)carbamate to afford the title compound $(26 \mathrm{mg}, 67 \%)$ as a white powder. ${ }^{1} \mathrm{H}$ NMR $\left(300 \mathrm{MHz}\right.$, Methanol- $\left.d_{4}\right) \delta 7.57(\mathrm{~d}, 2 \mathrm{H}), 7.49$ $(\mathrm{d}, J=8.2 \mathrm{~Hz}, 2 \mathrm{H}), 7.32(\mathrm{~d}, J=8.5 \mathrm{~Hz}, 2 \mathrm{H}), 7.26(\mathrm{~d}, J=8.0 \mathrm{~Hz}, 2 \mathrm{H}), 4.68(\mathrm{~d}, J=16.7 \mathrm{~Hz}, 1 \mathrm{H}), 4.57$ (d, $J=16.7 \mathrm{~Hz}, 1 \mathrm{H}), 3.91(\mathrm{~m}, 2 \mathrm{H}), 3.43-3.28(\mathrm{~m}, 1 \mathrm{H}), 3.17-2.97(\mathrm{~m}, 1 \mathrm{H}), 2.33(\mathrm{~s}, 3 \mathrm{H}), 1.81(\mathrm{~s}, 2 \mathrm{H})$, $1.75-1.53(\mathrm{~m}, 2 \mathrm{H}), 1.38(\mathrm{~s}, 3 \mathrm{H})$.

\section{$N$-(4-Cyanophenyl)-4-methyl- $N$-[2-[4-(methylamino)-1-piperidyl]-2-oxo-} ethyl]benzenesulfonamide (161).

Prepared by general method B using tert-butyl $N$-methyl- $N$-(piperidin-4-yl)carbamate to afford the title compound (21 mg, 39\%) as a white powder. ${ }^{1} \mathrm{H}$ NMR (300 MHz, Methanol- $\left.d_{4}\right) \delta$ 7.73-7.64 (m, 2H), 7.65-7.53 (m, 2H), 7.45-7.39 (m, 2H), 7.39-7.32 (m, 2H), $4.77(\mathrm{~d}, J=16.5 \mathrm{~Hz}, 1 \mathrm{H}), 4.63(\mathrm{~d}, J=$ $16.5 \mathrm{~Hz}, 1 \mathrm{H}), 4.51(\mathrm{~d}, J=14.0 \mathrm{~Hz}, 1 \mathrm{H}), 4.18(\mathrm{~d}, J=14.0 \mathrm{~Hz}, 1 \mathrm{H}), 3.31-3.13(\mathrm{~m}, 2 \mathrm{H}), 2.72(\mathrm{~s}, 3 \mathrm{H})$, 2.43 (s, 3H), 2.17 (m, 2H), 1.66 (qd, $J=12.3,4.3 \mathrm{~Hz}, 1 \mathrm{H}), 1.43$ (qd, $J=12.3,4.3 \mathrm{~Hz}, 1 \mathrm{H})$.

\section{$N$-(4-Cyanophenyl)- $N$-[2-[4-(dimethylamino)-1-piperidyl]-2-oxo-ethyl]-4-methyl- benzenesulfonamide $(16 \mathrm{~m})$.}

Prepared by general method A using 4-dimethylaminopiperidine to afford the title compound (26 mg, $65 \%)$ as a white powder. ${ }^{1} \mathrm{H}$ NMR $\left(300 \mathrm{MHz}\right.$, Methanol- $\left.d_{4}\right) \delta 7.71-7.63(\mathrm{~m}, 2 \mathrm{H}), 7.63-7.55(\mathrm{~m}, 2 \mathrm{H})$, 7.45-7.39 (m, 2H), 7.39-7.32 (m, 2H), $4.76(\mathrm{~d}, J=16.5 \mathrm{~Hz}, 1 \mathrm{H}), 4.64(\mathrm{~d}, J=16.5 \mathrm{~Hz}, 1 \mathrm{H}), 4.56(\mathrm{~d}, J$ $=14.0 \mathrm{~Hz}, 1 \mathrm{H}), 4.20(\mathrm{~d}, J=14.0 \mathrm{~Hz}, 1 \mathrm{H}), 3.19(\mathrm{t}, J=12.6 \mathrm{~Hz}, 1 \mathrm{H}), 2.78(\mathrm{~s}, 6 \mathrm{H}), 2.74-2.59(\mathrm{~m}, 1 \mathrm{H})$, $2.43(\mathrm{~s}, 3 \mathrm{H}), 2.12(\mathrm{~m}, 2 \mathrm{H}), 1.75(\mathrm{qd}, J=12.2,4.2 \mathrm{~Hz}, 1 \mathrm{H}), 1.51(\mathrm{dd}, J=12.2,4.2 \mathrm{~Hz}, 1 \mathrm{H})$.

\section{Preparation of compounds 21-27}

\section{1-Acetyl- $N$-(4-cyanophenyl)indoline-5-sulfonamide (18).}

Prepared in a manner analogous to compound $\mathbf{1 1}$ to afford the title compound as a light orange powder (486 mg, 84\%). ${ }^{1} \mathrm{H}$ NMR (300 MHz, DMSO-d 6 ) $\delta 10.95(\mathrm{~s}, 1 \mathrm{H}), 8.11(\mathrm{~d}, J=8.4 \mathrm{~Hz}, 1 \mathrm{H})$, 7.76-7.61 (m, 4H), 7.29-7.17 (m, 2H), $4.11(\mathrm{t}, J=8.6 \mathrm{~Hz}, 2 \mathrm{H}), 3.15(\mathrm{t}, J=8.6 \mathrm{~Hz}, 2 \mathrm{H}), 2.15$ (s, 3H). LC-MS: (High pH) t $\mathrm{t}_{\mathrm{R}} 0.76 \mathrm{~min}, \mathrm{~m} / \mathrm{z} 340.1[\mathrm{M}-\mathrm{H}]^{-}, 96 \%$ purity. 


\section{4-Cyano- $N$-(2-methylindazol-5-yl)benzenesulfonamide (19).}

To a stirred solution of 2-methyl-2H-indazol-5-amine $(1 \mathrm{~g}, 6.8 \mathrm{mmol})$ in pyridine $(0.9 \mathrm{~mL})$ and acetonitrile $(4 \mathrm{~mL})$ was added 4-cyanobenzenesulfonyl chloride $(1.51 \mathrm{~g}, 7.5 \mathrm{mmol})$. The reaction mixture was stirred at room temperature overnight, then water $(50 \mathrm{~mL})$ was added and the resulting light orange precipitate collected by filtration, washed with water $(3 \times 20 \mathrm{~mL})$ and dried under vacuum at $50{ }^{\circ} \mathrm{C}$ to the title compound $(1.15 \mathrm{~g}, 54 \%)$ as a light orange powder. ${ }^{1} \mathrm{H}$ NMR $(300 \mathrm{MHz}$, DMSO- $\left.d_{6}\right) \delta 10.36(\mathrm{~s}, 1 \mathrm{H}), 8.25(\mathrm{~s}, 1 \mathrm{H}), 8.00(\mathrm{~d}, J=8.4 \mathrm{~Hz}, 2 \mathrm{H}), 7.88-7.82(\mathrm{~m}, 2 \mathrm{H}), 7.82-7.74(\mathrm{~m}$, 1H), $7.49(\mathrm{dd}, J=9.1,0.9 \mathrm{~Hz}, 1 \mathrm{H}), 7.36(\mathrm{~d}, J=2.0 \mathrm{~Hz}, 1 \mathrm{H}), 6.98(\mathrm{dd}, J=9.1,2.0 \mathrm{~Hz}, 1 \mathrm{H}), 4.11(\mathrm{~s}$, 3H). LC-MS: (High $\mathrm{pH}) \mathrm{t}_{\mathrm{R}} 0.74 \mathrm{~min}, \mathrm{~m} / z 311.1[\mathrm{M}-\mathrm{H}]^{-}, 100 \%$ purity.

\section{1-Acetyl- $N$-[2-[(3R)-3-amino-1-piperidyl]-2-oxo-ethyl]- $N$-(4-cyanophenyl)indoline-5- sulfonamide (21a)}

A stirred suspension of $\mathbf{1 8}(30 \mathrm{mg}, 0.09 \mathrm{mmol})$, tert-butyl $N$-[(3R)-1-(2-chloroacetyl)-3piperidyl]carbamate (SI1, $27 \mathrm{mg}, 0.10 \mathrm{mmol})$, potassium carbonate $(18 \mathrm{mg}, 0.13 \mathrm{mmol})$ and potassium iodide $(2 \mathrm{mg})$ in DMF $(800 \mu \mathrm{L})$ was stirred at $80{ }^{\circ} \mathrm{C}$ for 3 hours. The reaction mixture was adsorbed onto silica and concentrated to dryness. Purification by CombiFlash (0 to $30 \%$ EtOAc in isohexane) afforded the Boc protected product. This was stirred in TFA $(0.5 \mathrm{~mL})$ and DCM $(3 \mathrm{~mL})$ then concentrated to dryness to afford the title compound (32 mg, 76\%) as a white powder, TFA salt. ${ }^{1} \mathrm{H}$ NMR (300 MHz, Methanol- $\left.d_{4}\right) \delta 8.19(\mathrm{~d}, J=8.8 \mathrm{~Hz}, 1 \mathrm{H}), 7.76-7.61(\mathrm{~m}, 2 \mathrm{H}), 7.55(\mathrm{~d}, J=8.4 \mathrm{~Hz}$, 2H), $7.44(\mathrm{~d}, J=8.4 \mathrm{~Hz}, 2 \mathrm{H}), 4.79(\mathrm{~d}, J=16.5 \mathrm{~Hz}, 1 \mathrm{H}), 4.67(\mathrm{~d}, J=16.5 \mathrm{~Hz}, 1 \mathrm{H}), 4.21(\mathrm{t}, J=8.6 \mathrm{~Hz}$, 2H), 3.93-3.77 (m, 1H), $3.67(\mathrm{~s}, 3 \mathrm{H}), 3.24$ (t, $J=8.9 \mathrm{~Hz}, 2 \mathrm{H}), 2.27$ (s, 3H), 2.20-2.09 (m, 1H), 1.99 $1.86(\mathrm{~m}, 1 \mathrm{H}), 1.83-1.64(\mathrm{~m}, 2 \mathrm{H}), 1.45(\mathrm{~d}, J=10.9 \mathrm{~Hz}, 1 \mathrm{H})$.

\section{1-Acetyl- $N$-[2-(4-amino-1-piperidyl)-2-oxo-ethyl]- $N$-(4-cyanophenyl)indoline-5-sulfonamide} (21b).

A stirred suspension of $\mathbf{1 8} \quad(50 \quad \mathrm{mg}, \quad 0.15 \quad \mathrm{mmol}), \quad$ tert-butyl $\quad N$-[1-(2-chloroacetyl)-4piperidyl]carbamate $(\mathbf{S I 2}, 49 \mathrm{mg}, 0.18 \mathrm{mmol})$ and potassium carbonate $(40 \mathrm{mg}, 0.29 \mathrm{mmol})$ in DMF $(1 \mathrm{~mL})$ was heated to $80{ }^{\circ} \mathrm{C}$ for $6 \mathrm{~h}$. EtOAc $(5 \mathrm{~mL})$ was added and the reaction mixture filtered 
through an Isolute filter cartridge, then concentrated to dryness. $4 \mathrm{M} \mathrm{HCl} /$ dioxane $(1 \mathrm{~mL})$ was then added. After $1 \mathrm{~h}$ the reaction mixture was concentrated to dryness under vacuum, and the resulting residue was purified by preparative HPLC (high $\mathrm{pH}$ ) to afford the title compound ( $29 \mathrm{mg}, 41 \%$ ) as a light yellow powder. ${ }^{1} \mathrm{H}$ NMR $\left(300 \mathrm{MHz}\right.$, Methanol- $\left.d_{4}\right) \delta 8.16(\mathrm{~d}, J=8.6 \mathrm{~Hz}, 1 \mathrm{H}), 7.71-7.59(\mathrm{~m}, 2 \mathrm{H})$, $7.53(\mathrm{~d}, J=7.8 \mathrm{~Hz}, 2 \mathrm{H}), 7.48-7.34(\mathrm{~m}, 2 \mathrm{H}), 4.79(\mathrm{~d}, J=16.5 \mathrm{~Hz}, 1 \mathrm{H}), 4.65(\mathrm{~d}, J=16.5 \mathrm{~Hz}, 1 \mathrm{H}), 4.47$ (d, $J=13.8 \mathrm{~Hz}, 1 \mathrm{H}), 4.29-4.09(\mathrm{~m}, 3 \mathrm{H}), 3.40$ (ddt, $J=11.8,7.4,4.1 \mathrm{~Hz}, 1 \mathrm{H}), 3.26-3.15(\mathrm{~m}, 3 \mathrm{H}), 2.73$ $(\mathrm{td}, J=13.3,12.6,2.8 \mathrm{~Hz}, 1 \mathrm{H}), 2.26(\mathrm{~s}, 3 \mathrm{H}), 2.14(\mathrm{~d}, J=12.5 \mathrm{~Hz}, 1 \mathrm{H}), 2.04(\mathrm{~d}, J=12.5 \mathrm{~Hz}, 1 \mathrm{H}), 1.68$ (qd, $J=11.8,4.1 \mathrm{~Hz}, 1 \mathrm{H}), 1.46(\mathrm{qd}, J=11.8,4.1 \mathrm{~Hz}, 1 \mathrm{H})$.

\section{$N$-[2-[(3R)-3-Amino-1-piperidyl]-2-oxo-ethyl]-4-cyano- $N$-(2-methylindazol-5- yl)benzenesulfonamide (22).}

Prepared in a manner analogous to compound 21a using sulfonamide $\mathbf{1 9}$ and SI1, to afford the title compound as a white powder, TFA salt $(18 \mathrm{mg}, 25 \%) .{ }^{1} \mathrm{H}$ NMR $\left(300 \mathrm{MHz}, \mathrm{DMSO}-d_{6}\right) \delta 8.32(\mathrm{~m}$, 2H), $8.17(\mathrm{~s}, 2 \mathrm{H}), 8.13-7.99(\mathrm{~m}, 3 \mathrm{H}), 7.83(\mathrm{t}, J=8.6 \mathrm{~Hz}, 2 \mathrm{H}), 7.59-7.45(\mathrm{~m}, 2 \mathrm{H}), 7.01$ (dd, $J=9.0$, $2.1 \mathrm{~Hz}, 1 \mathrm{H}), 4.81-4.68(\mathrm{~m}, 2 \mathrm{H}), 4.63(\mathrm{~d}, J=16.9 \mathrm{~Hz}, 1 \mathrm{H}), 4.14(\mathrm{~s}, 3 \mathrm{H}), 3.67(\mathrm{~m}, 1 \mathrm{H}), 3.15-3.05(\mathrm{~m}$, 1H), 3.02-2.83 (m, 1H), $1.93(\mathrm{~s}, 1 \mathrm{H}), 1.80-1.28(\mathrm{~m}, 2 \mathrm{H})$.

\section{1-Acetyl- $N$-[2-(4-amino-1-piperidyl)-2-oxo-ethyl]- $N$-[4-(3,5-dimethylpyrazol-1-yl)-3-methoxy- phenyl]indoline-5-sulfonamide (23).}

Prepared in a manner analogous to compound 21b using sulfonamide $\mathbf{2 0}$ and SI2, to afford the title compound as a white powder (34 mg, 52\%). ${ }^{1} \mathrm{H}$ NMR (300 MHz, Methanol- $\left.d_{4}\right) \delta 8.55(\mathrm{~s}, 1 \mathrm{H}), 8.20$ (d, $J=9.0 \mathrm{~Hz}, 1 \mathrm{H}), 7.60-7.49(\mathrm{~m}, 2 \mathrm{H}), 7.21(\mathrm{dd}, J=8.4,1.6 \mathrm{~Hz}, 1 \mathrm{H}), 7.07$ (d, $J=2.2 \mathrm{~Hz}, 1 \mathrm{H}), 6.90$ (dd, $J=8.4,2.2 \mathrm{~Hz}, 1 \mathrm{H}), 6.05-5.98(\mathrm{~m}, 1 \mathrm{H}), 4.73(\mathrm{~d}, J=16.2 \mathrm{~Hz}, 1 \mathrm{H}), 4.62(\mathrm{~d}, J=16.2 \mathrm{~Hz}, 1 \mathrm{H})$, $4.51(\mathrm{~d}, J=13.9 \mathrm{~Hz}, 1 \mathrm{H}), 4.20$ (t, $J=8.7 \mathrm{~Hz}, 3 \mathrm{H}), 3.71(\mathrm{~s}, 3 \mathrm{H}), 3.71(\mathrm{~s}, 1 \mathrm{H}), 3.39$ (td, $J=7.3,3.6 \mathrm{~Hz}$, 1H), $3.24(\mathrm{t}, J=8.7 \mathrm{~Hz}, 3 \mathrm{H}), 2.82-2.64(\mathrm{~m}, 1 \mathrm{H}), 2.27(\mathrm{~s}, 3 \mathrm{H}), 2.22(\mathrm{~d}, J=1.6 \mathrm{~Hz}, 3 \mathrm{H}), 2.12(\mathrm{~d}, J=$ $11.9 \mathrm{~Hz}, 1 \mathrm{H}), 2.06$ (s, 3H), 1.73-1.55 (m, 1H), 1.54-1.37 (m, 1H).

\section{Preparation of compounds 29-32}




\section{Route to glycine core}

tert-Butyl $N$-[1-[2-(4-cyanoanilino)acetyl]-4-piperidyl]carbamate (25).

To a solution of $\mathrm{N}$-(4-cyanophenyl)glycine (1 g, $5.7 \mathrm{mmol})$, COMU (2.95 g, $6.8 \mathrm{mmol})$ and 4-[(tertbutoxycarbonyl)amino]piperidine $(1.36 \mathrm{~g}, 6.8 \mathrm{mmol})$ in DMF $(10 \mathrm{~mL})$ was added $\mathrm{N}, \mathrm{N}-$ diisopropylethylamine (1.93 $\mathrm{mL}, 11.35 \mathrm{mmol})$. After $10 \mathrm{~min}$ a white precipitate formed. Stirring was continued for $30 \mathrm{~min}$, then water $(50 \mathrm{~mL})$ was added. The precipitate was filtered, washed with water $(3 \times 10 \mathrm{~mL})$ and dried to afford the title compound $(2.02 \mathrm{~g}, 99 \%)$ as a white powder. ${ }^{1} \mathrm{H}$ NMR (300 MHz, DMSO-d $\left.d_{6}\right) \delta 7.65-7.50(\mathrm{~m}, 2 \mathrm{H}), 6.86-6.73(\mathrm{~m}, 2 \mathrm{H}), 6.62(\mathrm{t}, J=5.1 \mathrm{~Hz}, 1 \mathrm{H}), 6.21(\mathrm{~d}, J=9.1$ $\mathrm{Hz}, 1 \mathrm{H}), 4.10(\mathrm{~d}, J=5.1 \mathrm{~Hz}, 2 \mathrm{H}), 3.66-3.48(\mathrm{~m}, 1 \mathrm{H}), 3.56-3.35(\mathrm{~m}, 3 \mathrm{H}), 3.42-3.29(\mathrm{~m}, 1 \mathrm{H}), 1.82-$ $1.67(\mathrm{~m}, 4 \mathrm{H}), 1.40(\mathrm{~s}, 9 \mathrm{H})$. f: (High $\mathrm{pH}) \mathrm{t}_{\mathrm{R}} 1.07 \mathrm{~min}, \mathrm{~m} / z 357.2[\mathrm{M}-\mathrm{H}]^{-}, 100 \%$ purity.

tert-Butyl $N$-[[1-[2-(4-cyanoanilino)acetyl]-4-piperidyl]methyl]carbamate (26).

To a solution of $N$-(4-cyanophenyl)glycine $(0.5 \mathrm{~g}, 2.8 \mathrm{mmol})$, COMU (730 mg, $3.4 \mathrm{mmol})$ in DMF $(10 \mathrm{~mL})$ was added $N, N$-diisopropylethylamine $(0.97 \mathrm{~mL}, 5.7 \mathrm{mmol})$. After $10 \mathrm{~min}$ a white precipitate formed. Stirring was continued for $30 \mathrm{~min}$, and then water $(50 \mathrm{~mL})$ was added. The resulting white precipitate was filtered, washed with water $(3 \times 10 \mathrm{~mL})$ and dried to afford the title compound $(1.04$ g, 98\%) as a white powder. ${ }^{1} \mathrm{H}$ NMR (300 MHz, DMSO- $\left.d_{6}\right) \delta 7.51-7.40(\mathrm{~m}, 2 \mathrm{H}), 6.90(\mathrm{t}, J=5.9 \mathrm{~Hz}$, 1H), 6.82-6.68 (m, 2H), $6.63(\mathrm{t}, J=5.1 \mathrm{~Hz}, 1 \mathrm{H}), 4.34(\mathrm{~d}, J=13.3 \mathrm{~Hz}, 1 \mathrm{H}), 3.98(\mathrm{t}, J=5.1 \mathrm{~Hz}, 2 \mathrm{H})$, $3.88(\mathrm{~d}, J=13.3 \mathrm{~Hz}, 1 \mathrm{H}), 2.97(\mathrm{t}, J=12.8 \mathrm{~Hz}, 1 \mathrm{H}), 2.87-2.78(\mathrm{~m}, 2 \mathrm{H}), 2.58(\mathrm{~d}, J=12.8 \mathrm{~Hz}, 1 \mathrm{H})$, $1.64(\mathrm{t}, J=10.8 \mathrm{~Hz}, 4 \mathrm{H}), 1.38(\mathrm{~s}, 9 \mathrm{H}), 1.20-0.79(\mathrm{~m}, 2 \mathrm{H})$. LC-MS: (High pH) $\mathrm{t}_{\mathrm{R}} 1.07 \mathrm{~min}, \mathrm{~m} / z 372.3$ $[\mathrm{M}-\mathrm{H}]^{-}, 100 \%$ purity.

tert-Butyl $N$-[[1-[2-(4-cyanoanilino)acetyl]-4-fluoro-4-piperidyl]methyl]carbamate (27).

Prepared in a manner analogous to compound 25 using $\mathbf{2 4}$ and tert-butyl N-[(4-fluoropiperidin-4yl)methyl]carbamate to afford the title compound (356 $\mathrm{mg}, 87 \%)$ as a pink powder. This product was used in the next step without further purification.

tert-Butyl 7-[2-(4-cyanoanilino)acetyl]-2,7-diazaspiro[3.5]nonane-2-carboxylate (28). 
To a solution of $N$-(4-cyanophenyl)glycine (370 mg, $2.1 \mathrm{mmol})$, COMU (1.08 g, $2.5 \mathrm{mmol})$ and tertbutyl-2,7-diazaspiro[3.5]nonane-2-carboxylate $(500 \mathrm{mg}, 2.2 \mathrm{mmol})$ in $\mathrm{DMF}(5 \mathrm{~mL})$ at $0{ }^{\circ} \mathrm{C}$ was added $\mathrm{N}, \mathrm{N}$-diisopropylethylamine $(0.71 \mathrm{~mL}, 4.2 \mathrm{mmol})$. After $10 \mathrm{~min}$ a white precipitate formed. Stirring was continued for $30 \mathrm{~min}$, then water $(50 \mathrm{~mL})$ was added. The precipitate was filtered, washed with water $(3 \times 10 \mathrm{~mL})$ and recrystallized from ethyl acetate $(30 \mathrm{~mL})$ to afford the title compound $(598 \mathrm{mg}$, $74 \%)$ as an off-white powder. ${ }^{1} \mathrm{H}$ NMR $\left(300 \mathrm{MHz}, \mathrm{DMSO}-d_{6}\right) \delta 7.50-7.41(\mathrm{~m}, 2 \mathrm{H}), 6.82-6.70(\mathrm{~m}$, 2H), 6.65 (t, $J=5.0 \mathrm{~Hz}, 1 \mathrm{H}), 3.99$ (d, $J=5.0 \mathrm{~Hz}, 2 \mathrm{H}), 3.59$ (br s, 4H), 3.40 (br s, 4H), 1.71 (t, $J=5.5$ $\mathrm{Hz}, 2 \mathrm{H}), 1.61(\mathrm{t}, J=5.5 \mathrm{~Hz}, 2 \mathrm{H}), 1.38(\mathrm{~s}, 9 \mathrm{H})$. LC-MS: (High pH) t $1.11 \mathrm{~min}, \mathrm{~m} / z 383.3[\mathrm{M}-\mathrm{H}]^{-}$, $98 \%$ purity.

\section{4-[[2-(4-Amino-1-piperidyl)-2-oxo-ethyl]-(p-tolylmethyl)amino]benzonitrile (29a).}

A stirred suspension of tert-butyl $N$-[1-[2-(4-cyanoanilino)acetyl]-4-piperidyl]carbamate (50 mg, 0.14 mmol), 4-methylbenzyl bromide ( $31 \mathrm{mg}, 0.17 \mathrm{mmol})$ and potassium carbonate $(48 \mathrm{mg}, 0.35 \mathrm{mmol}) \mathrm{in}$ $\operatorname{DMF}(500 \mu \mathrm{L})$ was heated to $80^{\circ} \mathrm{C}$ for $1 \mathrm{~h}$, then concentrated to dryness. $4 \mathrm{M} \mathrm{HCl}$ in dioxane $(1 \mathrm{~mL})$ was added and the reaction mixture stirred for $1 \mathrm{~h}$, then concentrated to dryness and purified by preparative HPLC (high $\mathrm{pH}$ ) to afford the title compound $\left(17 \mathrm{mg}, 34 \%\right.$ ) as a white powder. ${ }^{1} \mathrm{H}$ NMR $\left(300 \mathrm{MHz}\right.$, Methanol- $\left.d_{4}\right) \delta$ 7.53-7.32 (m, 2H), $7.16(\mathrm{~s}, 4 \mathrm{H}), 6.76-6.62(\mathrm{~m}, 2 \mathrm{H}), 4.63(\mathrm{~s}, 2 \mathrm{H}), 4.56(\mathrm{~d}$, $J=8.4 \mathrm{~Hz}, 1 \mathrm{H}), 4.48(\mathrm{~d}, J=4.5 \mathrm{~Hz}, 2 \mathrm{H}), 4.03(\mathrm{~d}, J=14.1 \mathrm{~Hz}, 1 \mathrm{H}), 3.47-3.33(\mathrm{~m}, 1 \mathrm{H}), 3.30-3.14(\mathrm{~m}$, 1H), $2.79(\mathrm{t}, J=12.3 \mathrm{~Hz}, 1 \mathrm{H}), 2.32(\mathrm{~s}, 3 \mathrm{H}), 2.12-2.05(\mathrm{~m}, 2 \mathrm{H}), 1.65$ (qd, $J=12.3,4.2 \mathrm{~Hz}, 1 \mathrm{H}), 1.51$ (qd, $J=12.3,4.2 \mathrm{~Hz}, 1 \mathrm{H})$.

\section{4-[(N-[2-(4-Amino-1-piperidyl)-2-oxo-ethyl]-4-cyano-anilino)methyl]-2-fluoro-benzonitrile} (29b).

Prepared in a manner analogous to compound 29a using 4-cyano-3-fluorobenzyl bromide to afford the title compound $(17 \mathrm{mg}, 15 \%)$ as a white powder. ${ }^{1} \mathrm{H}$ NMR $\left(300 \mathrm{MHz}\right.$, Methanol- $\left.d_{4}\right) \delta 7.74(\mathrm{dd}, J=$ 8.2, $6.7 \mathrm{~Hz}, 1 \mathrm{H}), 7.51-7.44(\mathrm{~m}, 2 \mathrm{H}), 7.42-7.31(\mathrm{~m}, 2 \mathrm{H}), 6.72-6.60(\mathrm{~m}, 2 \mathrm{H}), 4.78(\mathrm{~s}, 2 \mathrm{H}), 4.58(\mathrm{~d}, J=$ $9.1 \mathrm{~Hz}, 2 \mathrm{H}), 4.06(\mathrm{~d}, J=14.3 \mathrm{~Hz}, 1 \mathrm{H}), 3.51-3.34(\mathrm{~m}, 2 \mathrm{H}), 3.30-3.17(\mathrm{~m}, 1 \mathrm{H}), 2.81(\mathrm{t}, J=13.2 \mathrm{~Hz}$, $1 \mathrm{H}), 2.10(\mathrm{t}, J=13.2 \mathrm{~Hz}, 2 \mathrm{H}), 1.65(\mathrm{qd}, J=12.3,4.2 \mathrm{~Hz}, 1 \mathrm{H}), 1.51(\mathrm{qd}, J=12.3,4.2 \mathrm{~Hz}, 1 \mathrm{H})$. 


\section{4-[[2-(4-Amino-1-piperidyl)-2-oxo-ethyl]-[(3-fluoro-4-methoxy-}

phenyl)methyl]amino]benzonitrile (29c).

Prepared in a manner analogous to compound 29a using 3-fluoro-4-methoxybenzyl bromide to afford the title compound $(17 \mathrm{mg}, 31 \%)$ as a white powder. ${ }^{1} \mathrm{H}$ NMR $\left(300 \mathrm{MHz}\right.$, Methanol- $\left.d_{4}\right) \delta 7.55-7.36$ (m, 2H), 7.15-6.94 (m, 4H), 6.78-6.64 (m, 2H), $4.61(\mathrm{~s}, 3 \mathrm{H}), 4.51(\mathrm{~d}, J=6.0 \mathrm{~Hz}, 2 \mathrm{H}), 4.04(\mathrm{~d}, J=$ $14.2 \mathrm{~Hz}, 1 \mathrm{H}), 3.86(\mathrm{~s}, 3 \mathrm{H}), 3.23(\mathrm{t}, J=12.8 \mathrm{~Hz}, 1 \mathrm{H}), 2.80(\mathrm{t}, J=12.8 \mathrm{~Hz}, 1 \mathrm{H}), 2.09$ (t, $J=11.9 \mathrm{~Hz}$, $2 \mathrm{H}), 1.65(\mathrm{~m}, 1 \mathrm{H}), 1.50(\mathrm{~m}, 1 \mathrm{H}) .{ }^{19} \mathrm{~F}$ NMR $\left(300 \mathrm{MHz}\right.$, Methanol- $\left.d_{4}\right) \delta-135.7 .{ }^{13} \mathrm{C}$ NMR $(75 \mathrm{MHz}$, Chloroform- $d$ ) $\delta 168.6,154.0(\mathrm{~d}, J=245 \mathrm{~Hz}), 153.2,148.9,133.8,131.0(\mathrm{~d}, J=5.4 \mathrm{~Hz}), 122.5(\mathrm{~d}, J$ $=3.6 \mathrm{~Hz}), 120.7,115.8(\mathrm{~d}, J=18.8 \mathrm{~Hz}), 114.5,113.4,99.1,86.4,58.2,56.1,54.7,49.2,43.4,33.0$. HRMS (ESI) $m / z[\mathrm{M}+\mathrm{H}]^{+}$calcd for $\mathrm{C}_{22} \mathrm{H}_{26} \mathrm{O}_{2} \mathrm{~N}_{4} \mathrm{~F}$ : 397.2034. Found: 397.2022.

\section{4-[[2-(4-Amino-1-piperidyl)-2-oxo-ethyl]-benzyl-amino]benzonitrile (29d).}

Prepared in a manner analogous to 29a using benzyl bromide to afford the title compound (12 $\mathrm{mg}$, $25 \%)$ as a white powder. ${ }^{1} \mathrm{H}$ NMR $\left(300 \mathrm{MHz}\right.$, Methanol- $\left.d_{4}\right) \delta 7.51-7.39(\mathrm{~m}, 2 \mathrm{H}), 7.41-7.21(\mathrm{~m}, 5 \mathrm{H})$, 6.77-6.65 (m, 2H), $4.68(\mathrm{~s}, 2 \mathrm{H}), 4.64-4.41(\mathrm{~m}, 3 \mathrm{H}), 4.03(\mathrm{~d}, J=14.0 \mathrm{~Hz}, 1 \mathrm{H}), 3.43-3.27(\mathrm{~m}, 1 \mathrm{H})$, $3.21(\mathrm{t}, J=13.0 \mathrm{~Hz}, 1 \mathrm{H}), 2.79(\mathrm{t}, J=13.0 \mathrm{~Hz}, 1 \mathrm{H}), 2.17-1.95(\mathrm{~m}, 2 \mathrm{H}), 1.70-1.55(\mathrm{~m}, 1 \mathrm{H}), 1.58-1.39$ $(\mathrm{m}, 1 \mathrm{H})$.

\section{4-[[2-(4-Amino-1-piperidyl)-2-oxo-ethyl]-[(1-methylindazol-5-yl)methyl]amino]benzonitrile} (29e).

Prepared in a manner analogous to 29a using 5-(bromomethyl)-1-methyl-1H-indazole hydrobromide to afford the title compound (13 mg, 21\%) as a white powder. ${ }^{1} \mathrm{H}$ NMR (300 MHz, Methanol- $\left.d_{4}\right) \delta$ $7.93(\mathrm{~d}, J=0.9 \mathrm{~Hz}, 1 \mathrm{H}), 7.65(\mathrm{dd}, J=1.7,0.9 \mathrm{~Hz}, 1 \mathrm{H}), 7.56(\mathrm{dt}, J=8.6,0.9 \mathrm{~Hz}, 1 \mathrm{H}), 7.50-7.35$ (m, 3H), 6.80-6.69 (m, 2H), 4.79 (s, 2H), $4.61(\mathrm{~s}, 1 \mathrm{H}), 4.54$ (d, J=6.0 Hz, 2H), 4.06 (s, 3H), 4.01 (s, 1H), $3.46-3.28(\mathrm{~m}, 1 \mathrm{H}), 3.22(\mathrm{t}, J=13.0 \mathrm{~Hz}, 1 \mathrm{H}), 2.80(\mathrm{q}, J=12.1,11.7 \mathrm{~Hz}, 1 \mathrm{H}), 2.13-2.01(\mathrm{~m}, 2 \mathrm{H})$, $1.71-1.45(\mathrm{~m}, 2 \mathrm{H})$.

4-[[2-[4-(Aminomethyl)-1-piperidyl]-2-oxo-ethyl]-(p-tolylmethyl)amino]benzonitrile (30a). 
Prepared in a manner analogous to $\mathbf{3 0 b}$ (see below), affording the title compound ( $25 \mathrm{mg}, 47 \%$ ) as a white powder, bis-hydrochloride salt. ${ }^{1} \mathrm{H}$ NMR $\left(300 \mathrm{MHz}\right.$, Methanol- $\left.d_{4}\right) \delta$ 7.50-7.38 (m, 2H), 7.16 (s, 4H), 6.78-6.66 (m, 2H), $4.62(\mathrm{~s}, 2 \mathrm{H}), 4.55(\mathrm{~d}, J=13.7 \mathrm{~Hz}, 1 \mathrm{H}), 4.45(\mathrm{~s}, 2 \mathrm{H}), 3.96(\mathrm{~d}, J=14.0 \mathrm{~Hz}$, 1H), $3.15(\mathrm{q}, J=11.1,9.4 \mathrm{~Hz}, 1 \mathrm{H}), 2.95-2.84(\mathrm{~m}, 2 \mathrm{H}), 2.72(\mathrm{t}, J=13.1 \mathrm{~Hz}, 1 \mathrm{H}), 2.32(\mathrm{~s}, 3 \mathrm{H}), 1.97$ (tt, $J=7.3,3.8 \mathrm{~Hz}, 1 \mathrm{H}), 1.86(\mathrm{~d}, J=13.4 \mathrm{~Hz}, 2 \mathrm{H}), 1.40-1.15(\mathrm{~m}, 2 \mathrm{H}) .{ }^{13} \mathrm{C}$ NMR $(75 \mathrm{MHz}$, Methanol$\left.d_{4}\right) \delta 168.9,153.7,138.1,135.7,134.3,130.5,127.8,121.3,113.7,99.0,56.4,52.9,45.4,42.9,35.6$, 30.1, 21.1. HRMS (ESI) $m / z[\mathrm{M}+\mathrm{H}]^{+}$calcd for $\mathrm{C}_{23} \mathrm{H}_{29} \mathrm{ON}_{4}$ : 377.2336. Found: 377.2320 .

\section{4-[[2-[4-(Aminomethyl)-1-piperidyl]-2-oxo-ethyl]-[(4-chlorophenyl)methyl]amino]benzonitrile} (30b).

A stirred suspension of tert-butyl N-[[1-[2-(4-cyanoanilino)acetyl]-4-piperidyl]methyl]carbamate (50. $\mathrm{mg}, 0.14 \mathrm{mmol})$, 4-chlorobenzyl bromide $(43 \mathrm{mg}, 0.21 \mathrm{mmol})$ and potassium carbonate $(48 \mathrm{mg}, 0.35$ mmol) in DMF $\left(0.5 \mathrm{~mL}\right.$ ) was heated to $80{ }^{\circ} \mathrm{C}$ for $1 \mathrm{~h}$, then purified by HPLC (high $\mathrm{pH}$ ). $4 \mathrm{M} \mathrm{HCl}$ in dioxane $(1 \mathrm{~mL})$ was added and the reaction mixture concentrated to dryness to afford the title compound (27 mg, 37\%) as a white powder, bis-hydrochloride salt. ${ }^{1} \mathrm{H}$ NMR (300 MHz, Methanol- $\left.d_{4}\right)$ $\delta 7.42-7.29(\mathrm{~m}, 2 \mathrm{H}), 7.35-7.13(\mathrm{~m}, 6 \mathrm{H}), 6.58(\mathrm{dd}, J=9.8,2.8 \mathrm{~Hz}, 2 \mathrm{H}), 4.78(\mathrm{~d}, J=1.1 \mathrm{~Hz}, 2 \mathrm{H}), 4.55$ $(\mathrm{d}, J=7.0 \mathrm{~Hz}, 3 \mathrm{H}), 3.87(\mathrm{~d}, J=14.1 \mathrm{~Hz}, 1 \mathrm{H}), 3.14-2.98(\mathrm{~m}, 1 \mathrm{H}), 2.79(\mathrm{dd}, J=7.2,2.9 \mathrm{~Hz}, 2 \mathrm{H}), 1.76$ (s, 2H), 1.43-1.01 (m, 3H).

\section{4-[[2-[4-(Aminomethyl)-1-piperidyl]-2-oxo-ethyl]-[(4-fluorophenyl)methyl]amino]benzonitrile} (30c).

Prepared in a manner analogous to $\mathbf{3 0 b}$ using 4-fluorobenzyl bromide to afford the title compound (13 $\mathrm{mg}, 21 \%$ ) as a white powder, bis-hydrochloride salt. ${ }^{1} \mathrm{H}$ NMR (300 MHz, Methanol- $\left.d_{4}\right) \delta 7.40-7.28$ (m, 2H), 7.28-7.14 (m, 2H), 7.04-6.89 (m, 2H), 6.66-6.54 (m, 2H), 4.55 (s, 2H), 4.44 (d, J=13.2 Hz, 1H), 4.37 (s, 2H), 3.88 (d, $J=13.9 \mathrm{~Hz}, 1 \mathrm{H}), 3.70-3.54(\mathrm{~m}, 1 \mathrm{H}), 3.06(\mathrm{t}, J=13.0 \mathrm{~Hz}, 1 \mathrm{H}), 2.90-2.71$ (m, 2H), $2.62(\mathrm{td}, J=13.0,2.7 \mathrm{~Hz}, 1 \mathrm{H}), 1.97-1.66(\mathrm{~m}, 3 \mathrm{H}), 1.35$ (d, $J=13.0 \mathrm{~Hz}, 1 \mathrm{H}), 1.30-1.00$ (m, $2 \mathrm{H})$.

3-[(N-[2-[4-(Aminomethyl)-1-piperidyl]-2-oxo-ethyl]-4-cyano-anilino)methyl]benzamide (30d). 
Prepared in a manner analogous to $\mathbf{3 0 b}$ using 3-(chloromethyl)benzamide to afford the title compound (14 mg, 22\%) as a white powder, bis-hydrochloride salt. ${ }^{1} \mathrm{H}$ NMR $\left(300 \mathrm{MHz}\right.$, Methanol- $\left.d_{4}\right) \delta 7.76-$ $7.62(\mathrm{~m}, 2 \mathrm{H}), 7.49-7.29(\mathrm{~m}, 4 \mathrm{H}), 6.67-6.55(\mathrm{~m}, 2 \mathrm{H}), 4.63(\mathrm{~d}, J=1.8 \mathrm{~Hz}, 2 \mathrm{H}), 4.42(\mathrm{~s}, 3 \mathrm{H}), 3.89(\mathrm{~d}, J$ $=13.8 \mathrm{~Hz}, 1 \mathrm{H}), 3.21(\mathrm{t}, J=1.8 \mathrm{~Hz}, 1 \mathrm{H}), 3.06(\mathrm{t}, J=12.9 \mathrm{~Hz}, 1 \mathrm{H}), 2.84-2.74(\mathrm{~m}, 2 \mathrm{H}), 2.71-2.53(\mathrm{~m}$, $1 \mathrm{H}), 1.87(\mathrm{tt}, J=7.3,3.8 \mathrm{~Hz}, 2 \mathrm{H}), 1.76(\mathrm{~m}, 3 \mathrm{H}), 1.30-1.00(\mathrm{~m}, 2 \mathrm{H})$.

4-[(N-[2-[4-(Aminomethyl)-1-piperidyl]-2-oxo-ethyl]-4-cyano-anilino)methyl]benzamide (30e).

Prepared in a manner analogous to $\mathbf{3 0 b}$ using 4-(chloromethyl)benzamide to afford the title compound $(12 \mathrm{mg}, 18 \%)$ as a white powder, bis-hydrochloride salt. ${ }^{1} \mathrm{H}$ NMR $\left(300 \mathrm{MHz}\right.$, Methanol- $\left.d_{4}\right) \delta 7.81-$ $7.70(\mathrm{~m}, 2 \mathrm{H}), 7.39-7.33(\mathrm{~m}, 2 \mathrm{H}), 7.33-7.25(\mathrm{~m}, 2 \mathrm{H}), 6.59$ (d, J=9.0 Hz, 2H), $4.64(\mathrm{~s}, 2 \mathrm{H}), 4.49-4.42$ (m, 1H), $4.40(\mathrm{~s}, 2 \mathrm{H}), 3.88(\mathrm{~d}, J=14.1 \mathrm{~Hz}, 1 \mathrm{H}), 3.68-3.53(\mathrm{~m}, 4 \mathrm{H}), 3.06(\mathrm{t}, J=12.7 \mathrm{~Hz}, 1 \mathrm{H}), 2.78$ (dd, $J=6.9,4.1 \mathrm{~Hz}, 2 \mathrm{H}), 2.62(\mathrm{t}, J=12.6 \mathrm{~Hz}, 1 \mathrm{H}), 2.00-1.62(\mathrm{~m}, 2 \mathrm{H}), 1.44-1.00(\mathrm{~m}, 1 \mathrm{H})$.

\section{4-[[2-[4-(Aminomethyl)-1-piperidyl]-2-oxo-ethyl]-[(3-fluoro-4-methoxy-} phenyl)methyl]amino]benzonitrile (30f).

Prepared in a manner analogous to $\mathbf{3 0 b}$ using 3-fluoro-4-methoxybenzyl bromide to afford the title compound (23 mg, 40\%) as a white powder, bis-hydrochloride salt. ${ }^{1} \mathrm{H}$ NMR (300 MHz, Methanol- $\left.d_{4}\right)$ $\delta 7.42-7.29(\mathrm{~m}, 2 \mathrm{H}), 7.03-6.89(\mathrm{~m}, 3 \mathrm{H}), 6.67-6.55(\mathrm{~m}, 2 \mathrm{H}), 4.50(\mathrm{~s}, 2 \mathrm{H}), 4.43(\mathrm{~d}, J=14.7 \mathrm{~Hz}, 1 \mathrm{H})$, $4.36(\mathrm{~s}, 2 \mathrm{H}), 3.89$ (d, $J=14.7 \mathrm{~Hz}, 1 \mathrm{H}), 3.76(\mathrm{~s}, 3 \mathrm{H}), 3.06$ (t, $J=12.8 \mathrm{~Hz}, 1 \mathrm{H}), 2.79(\mathrm{dd}, J=6.8,3.7$ $\mathrm{Hz}, 2 \mathrm{H}), 2.62(\mathrm{t}, J=12.8 \mathrm{~Hz}, 1 \mathrm{H}), 1.96-1.53(\mathrm{~m}, 3 \mathrm{H}), 1.26-1.04(\mathrm{~m}, 2 \mathrm{H}) .{ }^{13} \mathrm{C}$ NMR $(75 \mathrm{MHz}$, MeOD) $\delta 169.0,153.9(\mathrm{~d}, J=247 \mathrm{~Hz}), 153.5,148.4,134.1,131.9(\mathrm{~d}, J=5.4 \mathrm{~Hz}), 124.2(\mathrm{~d}, J=3.6$ Hz), 121.0, 115.9, 114.5 (d, $J=18.9 \mathrm{~Hz}), 114.2,99.7,56.8,55.9,53.1,45.2,42.9,35.6,30.1$. HRMS (ESI) $m / z[\mathrm{M}+\mathrm{H}]^{+}$calcd for $\mathrm{C}_{23} \mathrm{H}_{28} \mathrm{O}_{2} \mathrm{~N}_{4} \mathrm{~F}: 411.2191$. Found: 411.2175 .

4-[[2-[4-(Aminomethyl)-4-fluoro-1-piperidy]]-2-oxo-ethyl]-[(3-fluoro-4-methoxyphenyl)methyl]amino]benzonitrile (31)

Prepared in a manner analogous to $\mathbf{3 0 b}$ using acid $\mathbf{2 7}$ as a starting material to afford the title compound as a white powder (9 mg, 17\%), bis-hydrochloride salt. ${ }^{1} \mathrm{H}$ NMR (300 MHz, Methanol- $\left.d_{4}\right)$ 
$\delta 7.45(\mathrm{dd}, J=8.9,4.0 \mathrm{~Hz}, 2 \mathrm{H}), 7.22-6.93(\mathrm{~m}, 2 \mathrm{H}), 6.83-6.62(\mathrm{~m}, 2 \mathrm{H}), 4.68-4.34(\mathrm{~m}, 4 \mathrm{H}), 3.88(\mathrm{~s}$, 3H), 3.86-3.54 (m, 2H), $3.67(\mathrm{~s}, 1 \mathrm{H}), 3.45(\mathrm{t}, J=12.5 \mathrm{~Hz}, 1 \mathrm{H}), 3.28(\mathrm{~d}, J=3.0 \mathrm{~Hz}, 1 \mathrm{H}), 3.22(\mathrm{~s}, 1 \mathrm{H})$, $3.05(\mathrm{t}, J=12.8 \mathrm{~Hz}, 1 \mathrm{H}), 2.17-1.57(\mathrm{~m}, 8 \mathrm{H}) .{ }^{19} \mathrm{~F}$ NMR $\left(282 \mathrm{MHz}\right.$, Methanol- $\left.d_{4}\right) \delta-136.50(\mathrm{~m}),-$ 169.24 (dddt, $J=38.0,29.5,20.2,10.0 \mathrm{~Hz})$.

\section{4-[[2-(2,7-Diazaspiro[3.5]nonan-7-yl)-2-oxo-ethyl]-[(3-fluoro-4-methoxy-}

phenyl)methyl]amino]benzonitrile (32).

A stirred suspension of $\mathbf{2 8}$ (330 mg, $0.64 \mathrm{mmol}$ ), 4-(bromomethyl)-2-fluoro-1-methoxybenzene (282 $\mathrm{mg}, 1.3 \mathrm{mmol})$ and potassium carbonate $(222 \mathrm{mg}, 1.6 \mathrm{mmol})$ in DMF $(3 \mathrm{~mL})$ was heated to $120^{\circ} \mathrm{C}$ by microwave irradiation for $0.5 \mathrm{~h}$. The reaction mixture was adsorbed onto silica then purified by automated column chromatography (0 to $70 \%$ EtOAc in isohexane). $4 \mathrm{M} \mathrm{HCl} /$ dioxane $(1 \mathrm{~mL})$ was added and the mixture stirred for 1 hour, then concentrated to dryness. The resulting residue was purified by preparative HPLC (high $\mathrm{pH}$ ) to afford the title compound (33 $\mathrm{mg}, 12 \%)$ as a white powder. ${ }^{1} \mathrm{H}\left\{{ }^{19} \mathrm{~F}\right\}$ NMR (300 MHz, Methanol- $\left.d_{4}\right) \delta{ }^{1} \mathrm{H}$ NMR (300 MHz, Methanol- $\left.d_{4}\right) \delta 8.58(\mathrm{~s}, 1 \mathrm{H})$, 7.51-7.39 (m, 2H), 7.13-6.99 (m, 3H), 6.76-6.65 (m, 2H), $4.60(\mathrm{~s}, 2 \mathrm{H}), 4.46(\mathrm{~s}, 2 \mathrm{H}), 3.86(\mathrm{~s}, 3 \mathrm{H})$, 3.57 (br m, 2H), 3.50 (br m, 3H), 3.36 (s, 1H), 1.93 (br m, 2H), 1.86 (br m, 2H). ${ }^{19} \mathrm{~F} \mathrm{NMR} \mathrm{(282} \mathrm{MHz,}$ Methanol- $\left.d_{4}\right) \delta-136.57(\mathrm{~m}) .{ }^{13} \mathrm{C}$ NMR $(75 \mathrm{MHz}, \mathrm{MeOD}) \delta 168.8,153.8\left(\mathrm{~d}, J_{\mathrm{C}, \mathrm{F}}=247 \mathrm{~Hz}\right), 153.3$, 148.2, 134.2, $131.9\left(\mathrm{~d}, J_{\mathrm{C}, \mathrm{F}}=5.4 \mathrm{~Hz}\right), 123.8\left(\mathrm{~d}, J_{\mathrm{C}, \mathrm{F}}=3.6 \mathrm{~Hz}\right), 121.3,115.5\left(\mathrm{~d}, J_{\mathrm{C}, \mathrm{F}}=18.9 \mathrm{~Hz}\right)$, 115.0, 113.8, 99.2, 86.4, 56.8, 56.3, 52.9, 49.9, 42.4, 40.0, 38.2, 35.3. HRMS (ESI) $m / z[\mathrm{M}+\mathrm{H}]^{+}$calcd for $\mathrm{C}_{24} \mathrm{H}_{28} \mathrm{O}_{2} \mathrm{~N}_{4} \mathrm{~F}: 423.2191$. Found: 423.2181 .

LSD1 enzymatic assay

Assays were performed in Corning ${ }^{\circledR} 384$ well low flange white flat bottom polystyrene (\#3574) microplates in a $10 \mu \mathrm{L}$ reaction volume consisting of $50 \mathrm{mM}$ TrisHCl, $50 \mathrm{mM} \mathrm{NaCl}, 1 \mathrm{mM}$ DTT, $0.01 \%$ Tween-20, $1 \%$ DMSO with or without compound in a 10-point, 3-fold dilution series, $0.2 \mu \mathrm{M}$ Histone H3(1-21)K4(Me1) biotin peptide substrate (AnaSpec Inc., Freemont, CA) and 1 nM LSD1 (Enzo Life Sciences, New York, NY). The reaction was allowed to proceed for $30 \mathrm{~min}$ at $25^{\circ} \mathrm{C}$ before stopping the reaction with the addition of $0.3 \mathrm{mM}$ tranylcypromine in LANCE detection buffer and 
quantifying the level of demethylated peptide by the addition of $1 \mathrm{nM}$ Europium- $\alpha$-unmodified H3K4 antibody and $25 \mathrm{nM}$ ULight Streptavidin (both from Perkin Elmer, Waltham, MA), also in LANCE detection buffer. Following a further 60 min incubation period the TR-FRET signal was read on a PHERAstar FS plate reader (BMG LabTech, Ortenberg, DE) with excitation at $340 \mathrm{~nm}$ and emission at $665 \mathrm{~nm}$.

SPR binding assay

Direct binding between compounds and LSD1 was assessed by SPR using Biacore T200, S200 and S51 instruments (GE Healthcare, Uppsala, Sweden). LSD1 was immobilized to CM5 or CM7 chips using amine coupling. Interaction experiments were performed at $15^{\circ} \mathrm{C}$ in $10 \mathrm{mM}$ HEPES, pH 7.4, $150 \mathrm{mM} \mathrm{NaCl}, 1 \% \mathrm{DMSO}, 0.05 \%$ Tween, at a flow rate of $30 \mathrm{~mL} / \mathrm{min}$. Compounds were diluted in the buffer and injected for $15-25 \mathrm{~s}$ at increasing concentrations over the prepared surfaces. Sensorgrams were double-referenced by subtracting signals from untreated reference channel and responses from blank injections. Affinities were derived by either dose-response analysis of steady state responses or regressions analysis of whole sensorgrams (1:1 interaction model including a term for mass transport limitation) using the T200 evaluation software 3.0 (GE Healthcare).

\section{Cell lines}

THP1 and MV4-11 cell lines were obtained from DSMZ (Braunschweig, Germany). All cell lines were cultured in RPMI supplemented with 10\% FBS and 2mM L-glutamine (Sigma Aldrich, Poole, UK).

Clonogenic assays

Clonogenic assays of human leukaemic cell lines were performed in methylcellulose medium (H4320, Stem Cell Technologies, Vancouver, BC) with no supplemental growth factors. Cells were seeded at $2.5 \times 10^{3}$ and colonies enumerated after 7 days in culture.

CD86 and apoptosis assays 
For CD86 assays, leukaemic cell lines were incubated in culture medium containing compounds or DMSO (vehicle control) for $48 \mathrm{~h}$ at a density of $1 \times 10^{5} / \mathrm{ml}$. Cells were pelleted, resuspended in $100 \mathrm{ml}$ SM buffer (Phenol red free RPMI, 5 mM EDTA and 2\% BSA (Sigma Aldrich)) containing 0.25ul CD86-PerCP EF710 (Clone IT2.2, eBioscience, Thermo Fisher Scientific) and incubated at $4{ }^{\circ} \mathrm{C}$ for 10 mins. Cells were washed, resuspended in SM buffer and analyzed by flow cytometry. To determine the effects of compounds on apoptosis, leukaemic cell lines were incubated with $10 \mu \mathrm{M}$ compound or vehicle for 4 days. Apoptosis was assessed using a BD Pharmingen PerCP-Cy5.5 Annexin V/7-AAD Kit (BD Biosciences), according to manufacturer's instructions. All FACS analyses were performed using either an LSR Model II (BD Biosciences, Oxford, UK) or NovoCyte (ACEA Biosciences) flow cytometer or FACSArray Bioanalyser (BD Biosciences).

\section{Glide docking}

Docking into the active site of LSD1 was carried out for each of the synthesized ligands. Molecules were docked in their predicted charged form at $\mathrm{pH}$ 7.4. Compounds were docked into the crystal structure of tetrahydrofolate bound to LSD1 (PDB code 4KUM) with all structural waters removed. Docking was performed in Glide 6.7, in standard precision mode and without further minimisation. Glidescore was used for conformation scoring of each ligand.

\section{ASSOCIATED CONTENT}

\section{Supporting Information}

The supporting information is available free of charge via the Internet at http://pubs.acs.org. SPR sensorgrams for selected compounds; LC-MS methods and solvent gradients; preparative HPLC instrument and solvent gradients; summary of purity data; molecular formula strings.

\section{Abbreviations}

AML, acute myeloid leukemia; APL, acute promyelocytic leukemia; ATRA, all-trans retinoic acid;

COMU, 1-Cyano-2-ethoxy-2-oxoethylidenaminooxy)dimethylamino-morpholino-carbenium hexafluorophosphate; DIPEA, N,N-diisopropylethylamine; GFI, growth factor independence; $K_{\mathrm{d}}$, 
dissociation constant; LSD1, lysine specific demethylase 1; MeCN, acetonitrile; MLL, mixed lineage leukemia; SPR, surface plasmon resonance; TR-FRET, time resolved fluorescence resonance energy transfer.

\section{AUTHOR INFORMATION}

\section{Corresponding author}

*Telephone: +44 (0)161-446-8079. Email: allan.jordan@cruk.manchester.ac.uk. Notes

Tim Somervaille has ongoing research collaborations with Oryzon Genomics and consults for Imago Biosciences. The other authors declare no competing financial interest.

\section{Acknowledgments}

This work was supported by Cancer Research UK (Grants C5759/A12328, C480/A11411, C5759/A17098 and C5759/A02901). Additional support was provided to DPM by the Society of Chemical Industry through a Messel Scholarship. HRMS spectra were generated by Gareth Smith, School of Chemistry, University of Manchester, Manchester, UK. Assistance with Glide docking was kindly provided by Bohdan Waszkowycz. In vitro pharmacokinetic and hERG data was provided by Cyprotex Discovery, Macclesfield, UK. JChem for Excel was used for structure property prediction and calculation, and general data handling (JChem for Excel, version 15.6.2900, 2008-2015, ChemAxon (http://www.chemaxon.com)). Ligand interaction diagrams in Figure 5 was generated within Maestro (Schrödinger, LLC, New York, NY), and images of protein-ligand complexes within the PyMOL Molecular Graphics System, Version 1.7.6.2. (Schrödinger, LLC, New York, NY).

\section{References}

1. Shi, Y.; Lan, F.; Matson, C.; Mulligan, P.; Whetstine, J. R.; Cole, P. A.; Casero, R. A.; Shi, Y. Histone demethylation mediated by the nuclear amine oxidase homolog LSD1. Cell 2004, 119, 941953. 
2. Amente, S.; Lania, L.; Majello, B. The histone LSD1 demethylase in stemness and cancer transcription programs. Biochim. Biophys. Acta, Gene Regul. Mech. 2013, 1829, 981-986.

3. Shi, Y.-J.; Matson, C.; Lan, F.; Iwase, S.; Baba, T.; Shi, Y. Regulation of LSD1 histone demethylase activity by its associated factors. Mol. Cell 2005, 19, 857-864.

4. Laurent, B.; Ruitu, L.; Murn, J.; Hempel, K.; Ferrao, R.; Xiang, Y.; Liu, S.; Garcia, Benjamin A.; Wu, H.; Wu, F.; Steen, H.; Shi, Y. A specific LSD1/KDM1A isoform regulates neuronal differentiation through H3K9 demethylation. Mol. Cell 2015, 57, 957-970.

5. Y Yang, M.; Gocke, C. B.; Luo, X.; Borek, D.; Tomchick, D. R.; Machius, M.; Otwinowski, Z.; Yu, H. Structural basis for CoREST-dependent demethylation of nucleosomes by the human LSD1 histone demethylase. Mol. Cell 2006, 23, 377-387.

6. Saleque, S.; Kim, J.; Rooke, H. M.; Orkin, S. H. Epigenetic regulation of hematopoietic differentiation by Gfi-1 and Gfi-1b is mediated by the cofactors CoREST and LSD1. Mol. Cell 2007, $27,562-572$.

7. Ishikawa, Y.; Gamo, K.; Yabuki, M.; Takegi, S.; Toyoshima, K.; Kazuhide, N.; Nakayama, A.; Morimoto, M.; Miyashita, H.; Dairiki, R.; Hikichi, Y.; Tomita, N.; Tomita, D.; Imamaura, S.; Iwatani, M.; Kamada, Y.; Matsumoto, S.; Hara, R.; Nomura, T.; Tsuchida, T.; Kazuhide, N. A novel LSD1 inihibitor T-3775440 disrupts GFI1B containing complex leading to transdifferentiation and imparied growth of AML cells. Mol. Cancer Ther. 2017, 16, 273-284

8. Velinder, M.; Singer, J.; Bareyan, D.; Meznarich, J.; Tracy, C. M.; Fulcher, J. M.; McClellan, D.; Lucente, H.; Franklin, S.; Sharma, S.; Engel, M. E. GFI1 functions in transcriptional control and cell fate determination require SNAG domain methylation to recruit LSD1. Biochem. J. 2016, 473, 3355.

9. Velinder, M. E.; Singer, J.; Meznarich, J.; Theisen, E. R.; Fulcher, J.; Tracy, C.; Franklin, S.; Sharma, S.; Engel, M. E. GFI1 snag domain methylation directs LSD1 recruitment to control transcription and cell fate determination in hematopoiesis. Blood 2015, 126, 46.

10. Harris, W. J.; Huang, X.; Lynch, J. T.; Spencer, G. J.; Hitchin, J. R.; Li, Y.; Ciceri, F.; Blaser, J. G.; Greystoke, B. F.; Jordan, A. M.; Miller, C. J.; Ogilvie, D. J.; Somervaille, T. C. P. The histone 
demethylase KDM1A sustains the oncogenic potential of MLL-AF9 leukemia stem cells. Cancer Cell 2012, 21, 473-487.

11. Döhner, H.; Estey, E. H.; Amadori, S.; Appelbaum, F. R.; Büchner, T.; Burnett, A. K.; Dombret, H.; Fenaux, P.; Grimwade, D.; Larson, R. A.; Lo-Coco, F.; Naoe, T.; Niederwieser, D.; Ossenkoppele, G. J.; Sanz, M. A.; Sierra, J.; Tallman, M. S.; Löwenberg, B.; Bloomfield, C. D. Diagnosis and management of acute myeloid leukemia in adults: recommendations from an international expert panel, on behalf of the European LeukemiaNet. Blood 2010, 115, 453-474.

12. Mohammad, H. P.; Smitheman, K. N.; Kamat, C. D.; Soong, D.; Federowicz, K. E.; Van Aller, G. S.; Schneck, J. L.; Carson, J. D.; Liu, Y.; Butticello, M.; Bonnette, W. G.; Gorman, S. A.; Degenhardt, Y.; Bai, Y.; McCabe, M. T.; Pappalardi, M. B.; Kasparec, J.; Tian, X.; McNulty, K. C.; Rouse, M.; McDevitt, P.; Ho, T.; Crouthamel, M.; Hart, T. K.; Concha, N. O.; McHugh, C. F.; Miller, W. H.; Dhanak, D.; Tummino, P. J.; Carpenter, C. L.; Johnson, N. W.; Hann, C. L.; Kruger, R. G. A DNA hypomethylation signature predicts antitumor activity of LSD1 inhibitors in SCLC. Cancer Cell 2015, 28, 57-69.

13. Hill, J. M.; Quenelle, D. C.; Cardin, R. D.; Vogel, J. L.; Clement, C.; Bravo, F. J.; Foster, T. P.; Bosch-Marce, M.; Raja, P.; Lee, J. S.; Bernstein, D. I.; Krause, P. R.; Knipe, D. M.; Kristie, T. M. Inhibition of LSD1 reduces herpesvirus infection, shedding, and recurrence by promoting epigenetic suppression of viral genomes. Sci. Transl. Med. 2014, 6, 265ra169

14. Liang, Y.; Quenelle, D.; Vogel, J. L.; Mascaro, C.; Ortega, A.; Kristie, T. M. A novel selective LSD1/KDM1A inhibitor epigenetically blocks herpes simplex virus lytic replication and reactivation from latency. mBio 2013, 4, e00558-12.

15. Buesa, C.; Mascaró, C.; Rotllant, D.; Griñan-Ferré, C.; Pallàs, M.; Maes, T. The dual LSD1/MAO-B inhibitor ORY2001 prevents the development of the memory deficit in samp8 mice through induction of neuronal plasticity and reduction of neuroinflammation. Alzheimer's Dementia 2015, 11, 905 .

16. Maes, T.; Arjol, C. B. Selective LSD1 and dual LSD1/MAO-B inhibitors for modulating diseases associated with alterations in protein conformation. U.S. Pat. Appl. 20160081947, 2016. 
17. Guibourt, N.; Munoz, A. O.; Laria, J. C.-P. Phenylcyclopropylamine derivatives and their medical use. U.S Pat. 8,993,808, 2015

18. Somervaille, T.; Salamero, O.; Montesinos, P.; Willekens, C.; Perez Simon, J. A.; Pigneux, A.; Recher, C.; Popat, R.; Molinero, C.; Mascaro, C.; Maes, T.; Bosch, F. Safety, phamacokinetics (PK), pharmacodynamics (PD) and preliminary activity in acute leukemia of ORY-1001, a first-inclass inhibitor of lysine-specific histone demethylase 1A (LSD1/KDM1A): initial results from a firstin-human phase 1 study. Blood 2016, 128, 4060.

19. Johnson, N. W.; Kasparec, J.; Rouse, M. B.; Tian, X.; Miller, W. H.; Suarez, D. Cyclopropylamines as LSD1 inhibitors. U.S. Pat. 9346840, 2016.

20. Yongchun, P.; Han, W.; Cao, G; Frietze, W.; Zhongjiang, J.; Sharief, V.; Zhou, J.; Li, Q. Salts of an LSD1 inhibitor. U.S. Pat. Appl. 201700440101, 2017.

21. Schenk, T.; Chen, W. C.; Gollner, S.; Howell, L.; Jin, L.; Hebestreit, K.; Klein, H.-U.; Popescu, A. C.; Burnett, A.; Mills, K.; Casero, R. A.; Marton, L.; Woster, P.; Minden, M. D.; Dugas, M.; Wang, J. C. Y.; Dick, J. E.; Muller-Tidow, C.; Petrie, K.; Zelent, A. Inhibition of the LSD1 (KDM1A) demethylase reactivates the all-trans-retinoic acid differentiation pathway in acute myeloid leukemia. Nat. Med. 2012, 18, 605-611.

22. Liu, X.; Stubbs, M.; Ye, M.; Collins, R.; Favata, M.; Yang, G.; Diamond, M.; Dostalik, V.; Lo, Y.; He, C.; Wu, L.; Combs, A.; Yao, W.; Hollis, G.; Huber, R.; Scherle, P.; Ruggeri, B.; Liu, P.; Lee, S. H. Abstract 4702: Combination of BET inhibitor INCB054329 and LSD1 inhibitor INCB059872 is synergistic for the treatment of AML in vitro and in vivo. Cancer Res. 2016, 76, 4702.

23. Vasilatos, S. N.; Katz, T. A.; Oesterreich, S.; Wan, Y.; Davidson, N. E.; Huang, Y. Crosstalk between lysine-specific demethylase 1 (LSD1) and histone deacetylases mediates antineoplastic efficacy of HDAC inhibitors in human breast cancer cells. Carcinogenesis 2013, 34, 1196-1207.

24. Mould, D. P.; McGonagle, A. E.; Wiseman, D. H.; Williams, E. L.; Jordan, A. M. Reversible inhibitors of LSD1 as therapeutic agents in acute myeloid leukemia: clinical significance and progress to date. Med. Res. Rev. 2015, 35, 586-618. 
25. Hitchin, J. R.; Blagg, J.; Burke, R.; Burns, S.; Cockerill, M. J.; Fairweather, E. E.; Hutton, C.; Jordan, A. M.; McAndrew, C.; Mirza, A.; Mould, D.; Thomson, G. J.; Waddell, I.; Ogilvie, D. J. Development and evaluation of selective, reversible LSD1 inhibitors derived from fragments. MedChemComm 2013, 4, 1513-1522.

26. Johnson, N. W. The identification of GSK2879552, a mechanism based irreversible inhibitor of the histone lysine demethylase LSD1. Presented at XXIV EFMC International Symposium on Medicinal Chemistry, Manchester, UK, August 28 - September 1, 2016.

27. Chen, Y., K.; Kanouni, T.; Nie, Z.; Stafford, J. A.; Veal, J. M.; Sung, L. M. Inhibitors of lysine specific demethylase-1. W.O. Pat. Appl. 2016004105, 2016.

28. Chen, Y. K.; Kanouni, T.; Kaldor, S. W.; Stafford, J. A.; Veal, J. M. Inhibitors of lysine specific demethylase-1. W.O. Pat. Appl. 2015089192, 2015

29. Chen, Y. K.; Kanouni, T.; Nie, Z.; Stafford, J. A.; Veal, J. M.; Sung, L. M. Inhibitors of lysine specific demethylase-1. W.O. Pat. Appl. 2016003917, 2016.

30. Liangxing, W.; Courter, J. R.; Chunhong, H.; Jingwei, L.; Liang, L.; Yaping, S.; Xiaozhao, W.; Wenqing, Y.; Zhang, C.; Jincong, Z. Imidazopyrazines as LSD1 inhibitors. U.S. Pat. Appl. $20160009720,2016$.

31. Liangxing, W.; Konkol, L. C.; Lajkiewicz, N.; Liang, L.; Meizhong, X.; Wenqing, Y.; Zhang, C.; Chunhong He. Imidazopyridines and imidazopyrazines as LSD1 inhibitors. U.S. Pat. Appl. $20160009712,2016$.

32. Liangxing, W.; Xiaozhao, W.; Wenqing, Y.; Zhang, C. Triazolopyridines and triazolopyrazines as LSD1 Inhibitors. U.S. Pat. Appl. 20160009711, 2016.

33. Sartori, L.; Mercurio, C.; Amigoni, F.; Cappa, A.; Fagá, G.; Fattori, R.; Legnaghi, E.; Ciossani, G.; Mattevi, A.; Meroni, G.; Moretti, L.; Cecatiello, V.; Pasqualato, S.; Romussi, A.; Thaler, F.; Trifiró, P.; Villa, M.; Vultaggio, S.; Botrugno, O. A.; Dessanti, P.; Minucci, S.; Zagarrí, E.; Carettoni, D.; Iuzzolino, L.; Varasi, M.; Vianello, P. Thieno[3,2-b]pyrrole-5-carboxamides as new reversible inhibitors of histone lysine demethylase KDM1A/LSD1. Part 1: high throughput screening and preliminary exploration. J. Med. Chem. 2017, 60, 1673-1692. 
34. Vianello, P.; Sartori, L.; Amigoni, F.; Cappa, A.; Fagá, G.; Fattori, R.; Legnaghi, E.; Ciossani, G.; Mattevi, A.; Meroni, G.; Moretti, L.; Cecatiello, V.; Pasqualato, S.; Romussi, A.; Thaler, F.; Trifiró, P.; Botrugno, O. A.; Villa, M.; Dessanti, P.; Minucci, S.; Vultaggio, S.; Zagarrí, E.; Varasi, M.; Mercurio, C. Thieno[3,2-b]pyrrole-5-carboxamides as new reversible inhibitors of histone lysine demethylase KDM1A/LSD1. Part 2: structure based drug design and structure-activity relationship. $J$. Med. Chem. 2017, 60, 1693-1715.

35. Speranzini, V.; Rotili, D.; Ciossani, G.; Pilotto, S.; Marrocco, B.; Forgione, M.; Lucidi, A.; Forneris, F.; Mehdipour, P.; Velankar, S.; Mai, A.; Mattevi, A. Polymyxins and quinazolines are LSD1/KDM1A inhibitors with unusual structural features. Sci. Adv. 2016, 2 (9), e1601017.

36. Song, Y.; Xue, X.; Wu, X.; Wang, R.; Xing, Y.; Yan, W.; Zhou, Y.; Qian, C.-N.; Zhang, Y.; $\mathrm{Xu}, \mathrm{Y}$. Identification of N-phenyl-2-(N-phenylphenylsulfonamido)acetamides as new ROR $\gamma$ inverse agonists: Virtual screening, structure-based optimization, and biological evaluation. Eur. J. Med. Chem. 2016, 116, 13-26.

37. Lynch, J. T.; Cockerill, M. J.; Hitchin, J. R.; Wiseman, D. H.; Somervaille, T. C. P. CD86 expression as a surrogate cellular biomarker for pharmacological inhibition of the histone demethylase lysine-specific demethylase 1. Anal. Biochem. 2013, 442, 104-106.

38. Wu, F.; Zhou, C.; Yao, Y.; Wei, L.; Feng, Z.; Deng, L.; Song, Y. 3-(Piperidin-4ylmethoxy)pyridine containing compounds are potent inhibitors of lysine specific demethylase $1 . J$. Med. Chem. 2016, 59, 253-263.

39. Cheeseright, T. J.; Mackey, M. D.; Melville, J. L.; Vinter, J. G. FieldScreen: virtual screening using molecular fields. Application to the DUD data set. J. Chem. Inf. Model 2008, 48, 2108-2117.

40. Park, B. K.; Boobis, A.; Clarke, S.; Goldring, C. E. P.; Jones, D.; Kenna, J. G.; Lambert, C.; Laverty, H. G.; Naisbitt, D. J.; Nelson, S.; Nicoll-Griffith, D. A.; Obach, R. S.; Routledge, P.; Smith, D. A.; Tweedie, D. J.; Vermeulen, N.; Williams, D. P.; Wilson, I. D.; Baillie, T. A. Managing the challenge of chemically reactive metabolites in drug development. Nat. Rev. Drug Discovery 2011, $10,292-306$. 
41. Luka, Z.; Pakhomova, S.; Loukachevitch, L. V.; Calcutt, M. W.; Newcomer, M. E.; Wagner, C. Crystal structure of the histone lysine specific demethylase LSD1 complexed with tetrahydrofolate. Protein Sci. 2014, 23, 993-998.

42. Friesner, R. A.; Banks, J. L.; Murphy, R. B.; Halgren, T. A.; Klicic, J. J.; Mainz, D. T.; Repasky, M. P.; Knoll, E. H.; Shelley, M.; Perry, J. K.; Shaw, D. E.; Francis, P.; Shenkin, P. S. Glide: a new approach for rapid, accurate docking and scoring. 1. Method and assessment of docking accuracy. J. Med. Chem. 2004, 47, 1739-1749. 


\section{TABLE OF CONTENTS GRAPHIC}
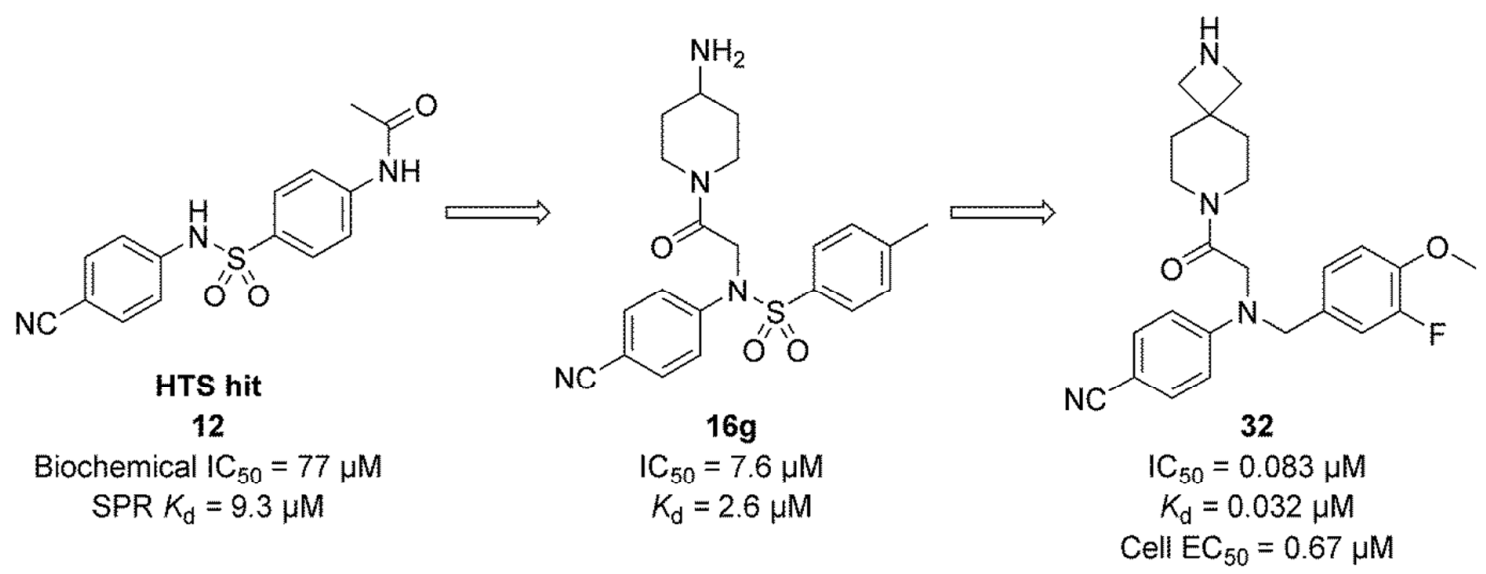

19

20

21

22

23

24

25

26

27

28

29

30

31

32

33

34

35

36

37

38

39

40

41

42

43

44

45

46

47

48

49

50

51

52

53

54

55

56

57

58

59

60 

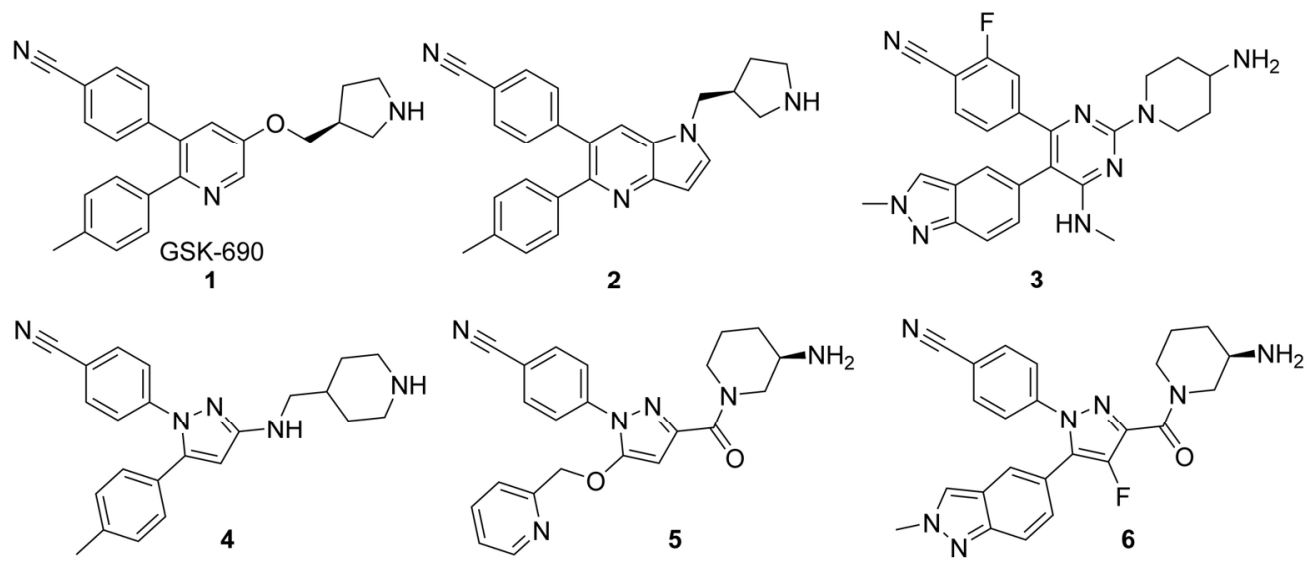

Figure 1. Compound $\mathbf{1}$ and examples from several series disclosed by Quanticel Pharmaceuticals in WO2015/089192 (2-6). ${ }^{25}$

$77 \times 33 \mathrm{~mm}(600 \times 600$ DPI $)$ 
1

2

3

4

5

6

7

8

9

10

11

12

13

14

15

16

17

18

19

20

21

22

23

24

25

26

27

28

29

30

31

32

33

34

35

36

37

38

39

40

41

42

43

44

45

46

47

48

49

50

51

52

53

54

55

56

57

58

59

60
A

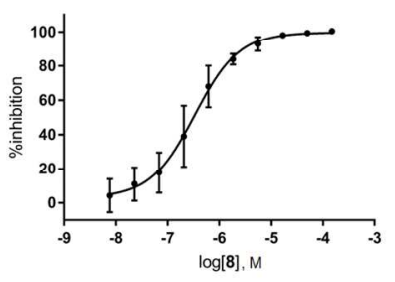

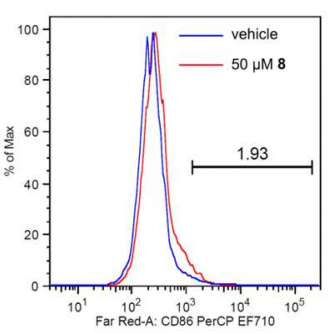

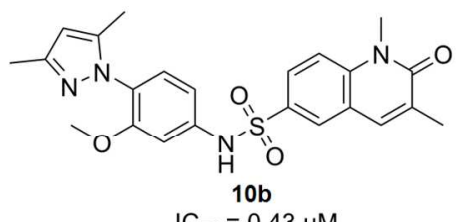

$\mathrm{IC}_{50}=0.43 \mu \mathrm{M}$

$\left.\begin{array}{l}\text { SPR } \\ \text { Cell }\end{array}\right\}$ No activity

C

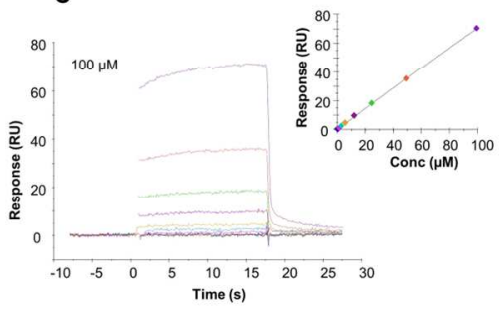

Figure 2. Development and characterization of compound 10b. A: Biochemical assay; B: Surrogate cellular biomarker assay; C: Surface plasmon resonance sensorgram of the interaction between LSD1 and $\mathbf{1 0 b}$ in two-fold dilution series (highest concentration indicated in the graph).

$422 \times 211 \mathrm{~mm}(96 \times 96$ DPI $)$ 


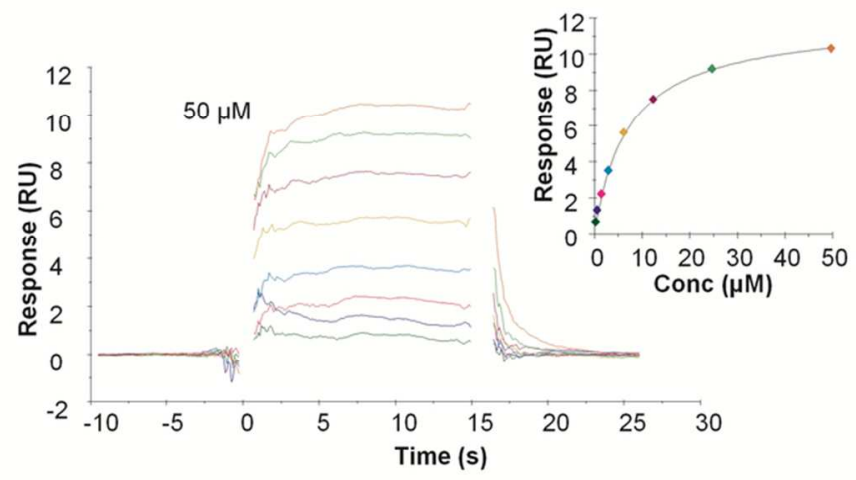

Figure 3. Structure of compound $\mathbf{1 2}$ with biochemical and SPR sensorgram indicating the highest tested concentration. $K_{\mathrm{d}}=9.5 \mu \mathrm{M}$. $K_{\mathrm{d}}$ value was determined by SPR at $15^{\circ} \mathrm{C}$ as the average of two experimental series (typically 10 concentrations).

$41 \times 15 \mathrm{~mm}(600 \times 600 \mathrm{DPI})$ 
1

2

3

4

5

6

7

8

9

10

11

12

13

14

15

16

17

18

19

20

21

22

23

24

25

26

27

28

29

30

31

32

33

34

35

36

37

38

39

40

41

42

43

44

45

46

47

48

49

50

51

52

53

54

55

56

57

58

59

60

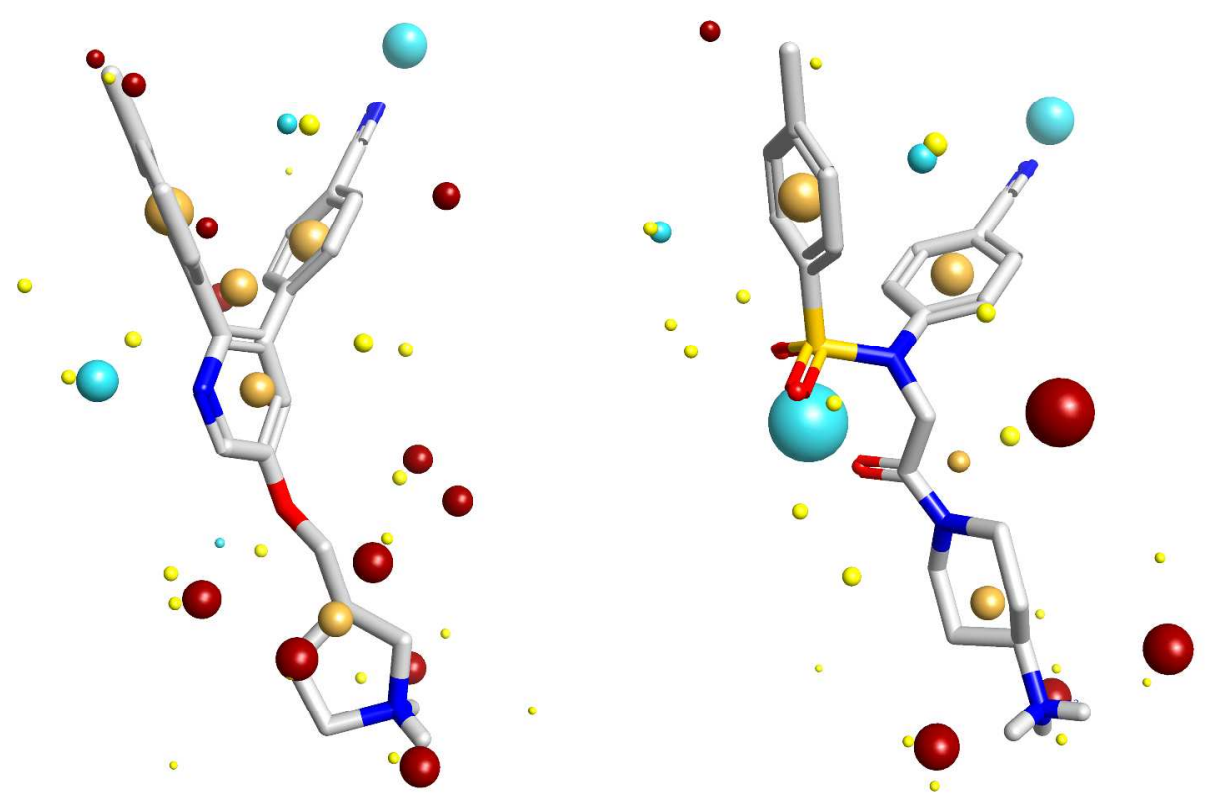

Figure 4. Cresset Torch alignment and structures of compound $\mathbf{1}$ (left) and $\mathbf{1 6 g}$ (right). Similarity score 0.712 . Blue field points (spheres) highlight energy minima for a positively charged probe, red for a negative probe. Yellow spheres represent an attractive van der Waals minimum for a neutral probe and brown spheres represent hydrophobic regions. Oxygen atoms are shown in red, nitrogen in blue. The similarity score is based on the likeness of the field points in terms of their magnitude and position. A score of greater than 0.7 is considered a 'good' score.

$1068 \times 696 \mathrm{~mm}(96 \times 96 \mathrm{DPI})$ 


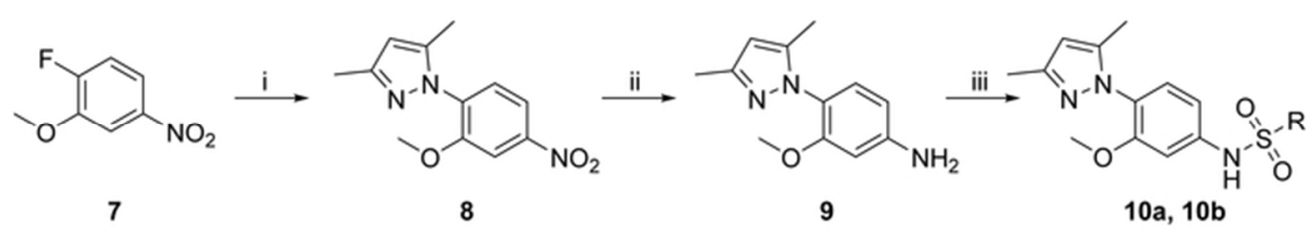

Scheme 1: Synthesis of compounds 10a-ba

${ }^{a}$ Reagents and conditions: (i) 3,5-dimethylpyrazole, $\mathrm{K}_{2} \mathrm{CO}_{3}$, DMF, $80{ }^{\circ} \mathrm{C}, 16 \mathrm{~h}, 99 \%$; (ii) $\mathrm{Zn}$, ammonium formate, $\mathrm{MeOH}, 40^{\circ} \mathrm{C}, 16 \mathrm{~h}, 78 \%$; (iii) appropriate sulfonyl chloride, pyridine, $100{ }^{\circ} \mathrm{C}, 1 \mathrm{~h}, 41-70 \%$.

$29 \times 4 \mathrm{~mm}(600 \times 600 \mathrm{DPI})$ 
${ }^{a}$ Reagents and conditions: (i) 4-acetamidobenzenesulfonyl chloride, DMAP, MeCN, $\mu \mathrm{W}, 100{ }^{\circ} \mathrm{C}, 1 \mathrm{~h}, 37 \%$ (ii) 4-methylphenylsulfonyl, pyridine, $\mathrm{MeCN}, \mathrm{RT}, 12 \mathrm{~h}, 89 \%$; (iii) tert-butyl bromoacetate, $\mathrm{K}_{2} \mathrm{CO}_{3}, \mathrm{DMF}, 1 \mathrm{~h}$, 96\%; (iv) TFA, DCM, $1 \mathrm{~h}, 98 \%$; (v) amine, DIPEA, COMU, DMF, then $4 \mathrm{M} \mathrm{HCl} /$ dioxane if Boc deprotection required, $\mathrm{RT}, 12-68 \%$.

$85 \times 45 \mathrm{~mm}(600 \times 600 \mathrm{DPI})$ 


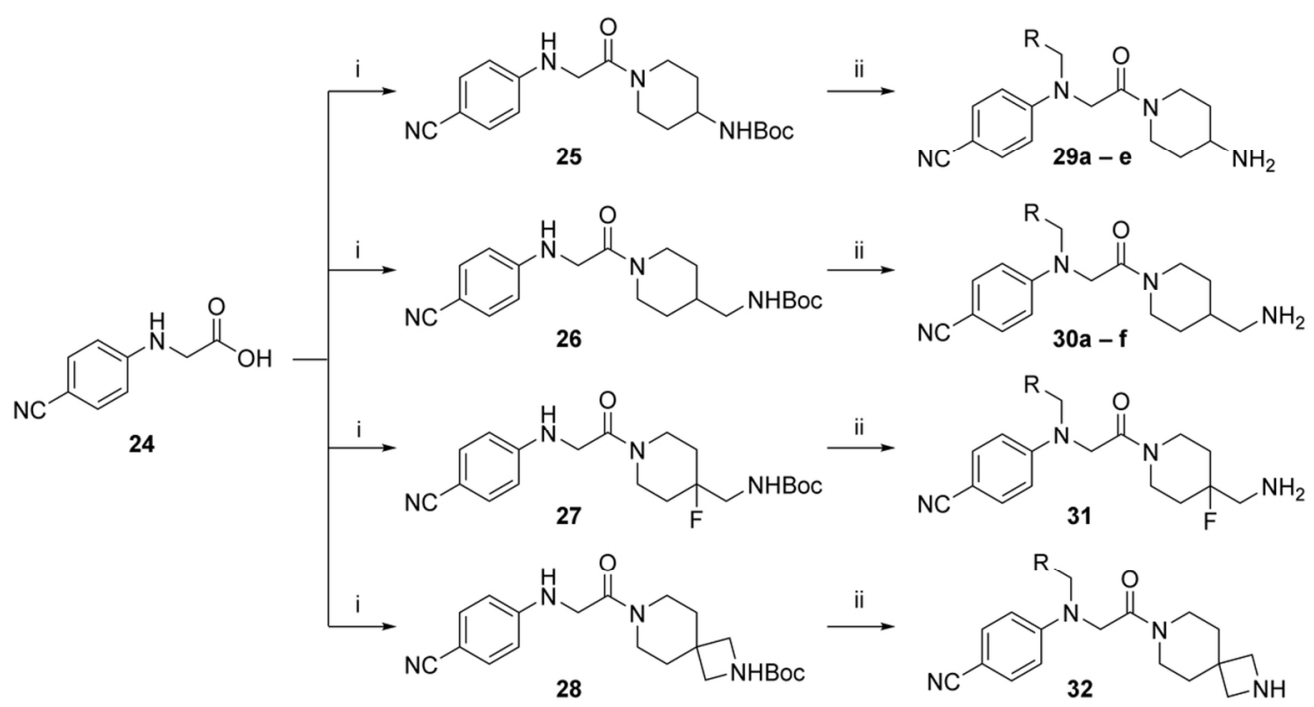

Scheme 4: Synthesis of compounds 29a-e, 30a-f, 31 and $\mathbf{3 2}^{\mathbf{a}} \vdash+\vdash{ }_{T}{ }^{\mathrm{a}}$ Reagents and conditions: i) Boc-protected diamine, DIPEA, COMU, DMF, $\mathrm{rt}, 1 \mathrm{~h}, 67-99 \%$; ii) substituted benzyl-bromide, $\mathrm{K}_{2} \mathrm{CO}_{3}$, DMF, $80^{\circ} \mathrm{C}, 1 \mathrm{~h}$, then $4 \mathrm{M} \mathrm{HCl} /$ dioxane, $\mathrm{rt}, 1 \mathrm{~h}, 6-58 \%$

$103 \times 55 \mathrm{~mm}(300 \times 300$ DPI) 
Scheme 3: Synthesis of compounds $21 \mathbf{a}-\mathbf{b}, \mathbf{2 2}$ and $23^{\mathbf{a}}+\vdash_{T}{ }^{a}$ Reagents and conditions: (i) 1acetylindoline-5-sulfonyl chloride, pyridine, MeCN, RT, 12 h, 84\%; (ii) (21a) tert-butyl N-[(3R)-1-(2chloroacetyl)-3-piperidyl]carbamate, $\mathrm{K}_{2} \mathrm{CO}_{3}$, cat. $\mathrm{KI}, \mathrm{DMF}, 80{ }^{\circ} \mathrm{C}, 3 \mathrm{~h}$; then TFA, $1 \mathrm{~h}, \mathrm{RT}$, 42\%; (21b) tertbutyl N-[1-(2-chloroacetyl)-4-piperidyl]carbamate, $\mathrm{K}_{2} \mathrm{CO}_{3}, 80^{\circ} \mathrm{C}, 6 \mathrm{~h}$, then $4 \mathrm{M} \mathrm{HCl} /$ dioxane, $70 \%$; (iii) 2methyl-2H-indazol-5-amine, pyridine, MeCN, RT, 12 h, 54\%; (iv) tert-butyl N-[(3R)-1-(2-chloroacetyl)-3piperidyl]carbamate, $\mathrm{K}_{2} \mathrm{CO}_{3}$, cat. $\mathrm{KI}, \mathrm{DMF}, 80^{\circ} \mathrm{C}, 3 \mathrm{~h}$; then TFA, $1 \mathrm{~h}, \mathrm{RT}, 25 \%$; ( $\mathrm{v}$ ) 1-acetylindoline-5sulfonyl chloride, pyridine, MeCN, RT, 12 h, 54\%; (vi) tert-butyl N-[1-(2-chloroacetyl)-4piperidyl]carbamate, $\mathrm{K}_{2} \mathrm{CO}_{3}, \mathrm{DMF}, 80^{\circ} \mathrm{C}, 6 \mathrm{~h}$, then $4 \mathrm{M} \mathrm{HCl} /$ dioxane, $1 \mathrm{~h} \mathrm{RT}, 52 \%$.

$109 \times 71 \mathrm{~mm}(300 \times 300$ DPI $)$ 

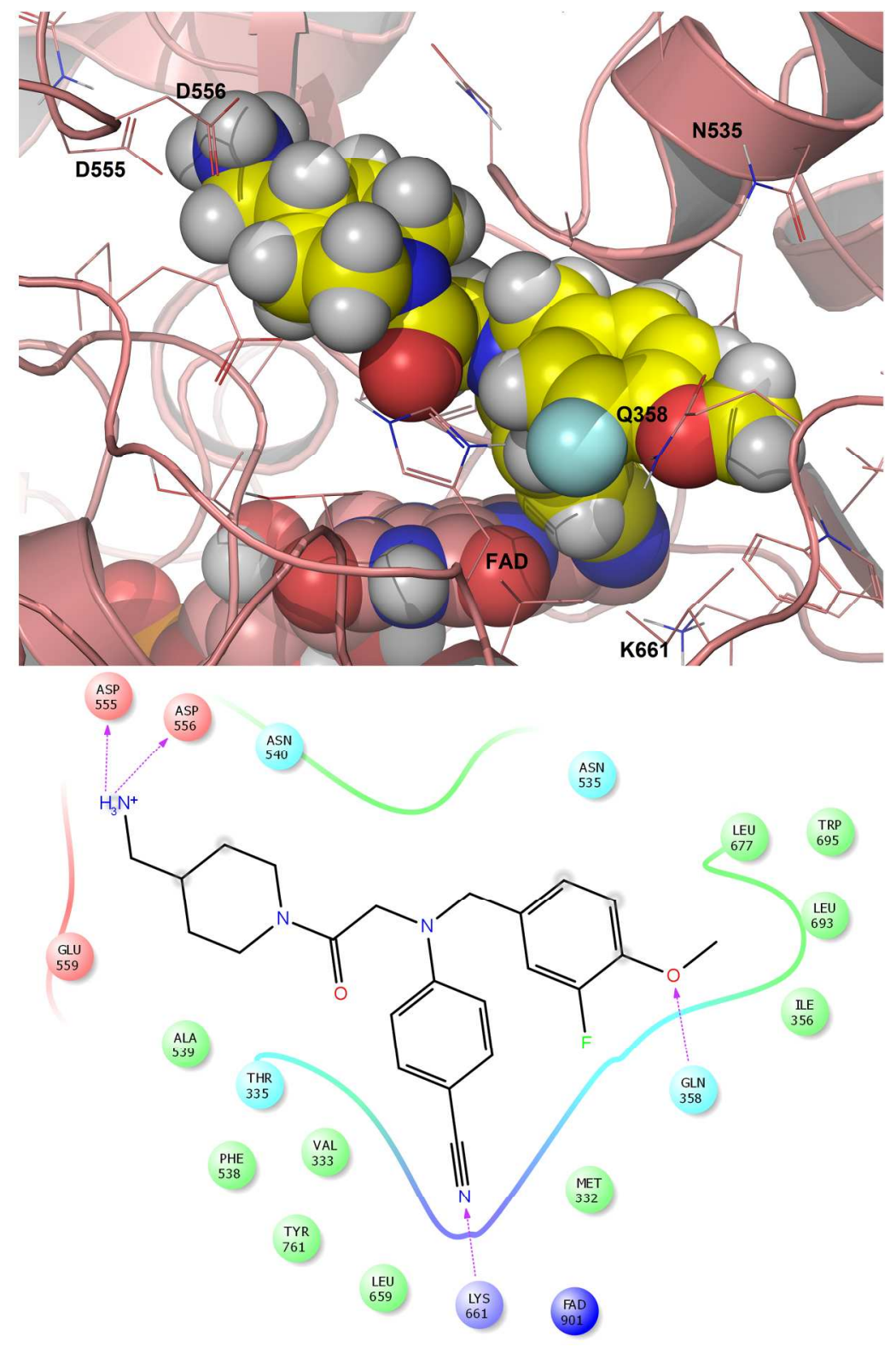

Figure 5. Top: Predicted binding mode of compound $\mathbf{3 0}$ in the LSD1 active site (4KUM). Visualized using Maestro. Bottom: Protein-ligand interaction diagram with key hydrogen bond interactions highlighted (pink arrows).

$490 \times 752 \mathrm{~mm}(96 \times 96 \mathrm{DPI})$ 


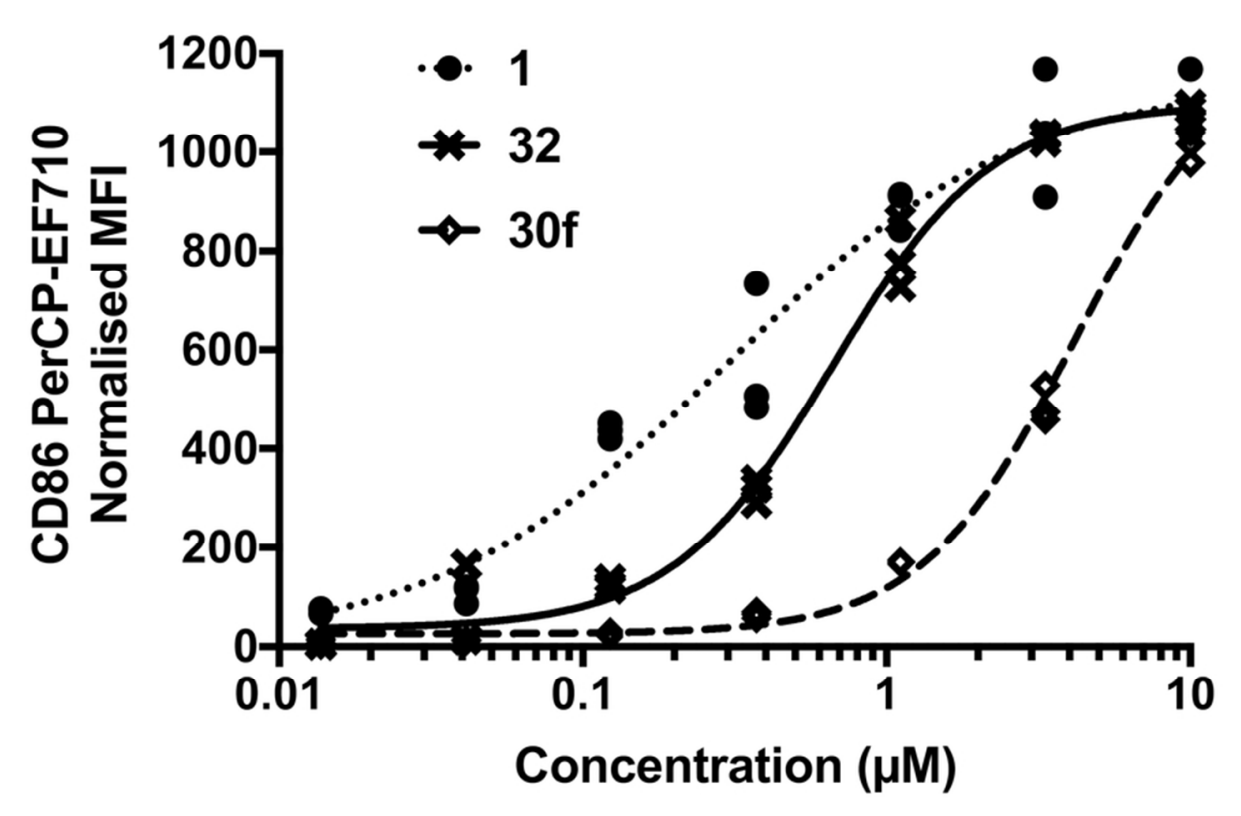

Figure 6. CD86 cell assay results for compounds $\mathbf{1}, \mathbf{3 0 f}$ and $\mathbf{3 2 .}$

$80 \times 50 \mathrm{~mm}(300 \times 300$ DPI $)$ 


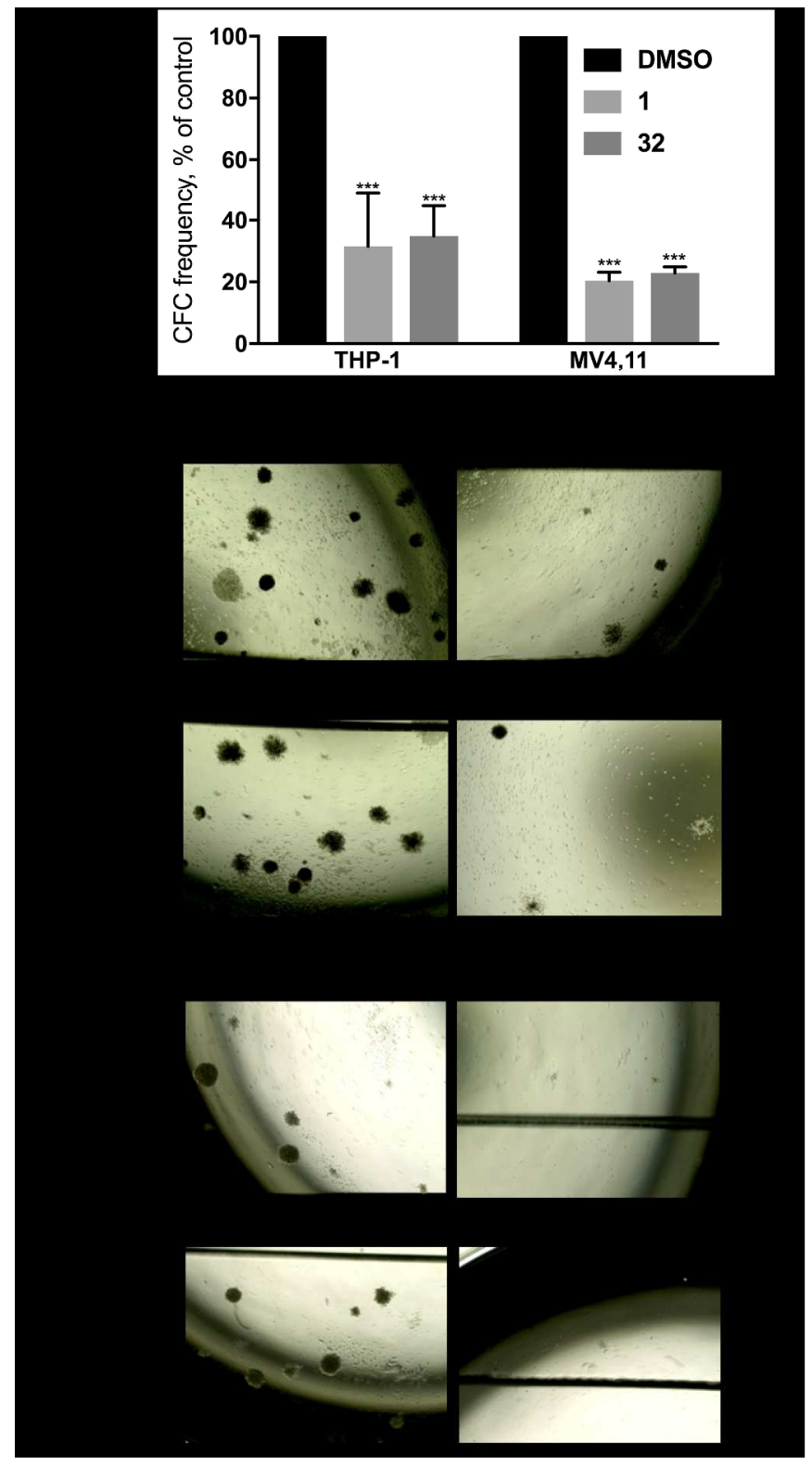

Figure 7. Top: Colony formation assay for THP-1 and MV4-11 cells dosed with $10 \mu \mathrm{M}$ of compounds 1 and 32 for 7 days. $* \mathrm{P}<0.05, * * \mathrm{P}<0.01, * * * \mathrm{P}<0.001, * * * * \mathrm{P}<0.0001$, statistical significance calculated using a oneway ANOVA with Dunnett's tests between vehicle treated and compound dosed cells. Bottom: representative images of colonies.

$251 \times 461 \mathrm{~mm}(300 \times 300$ DPI $)$ 


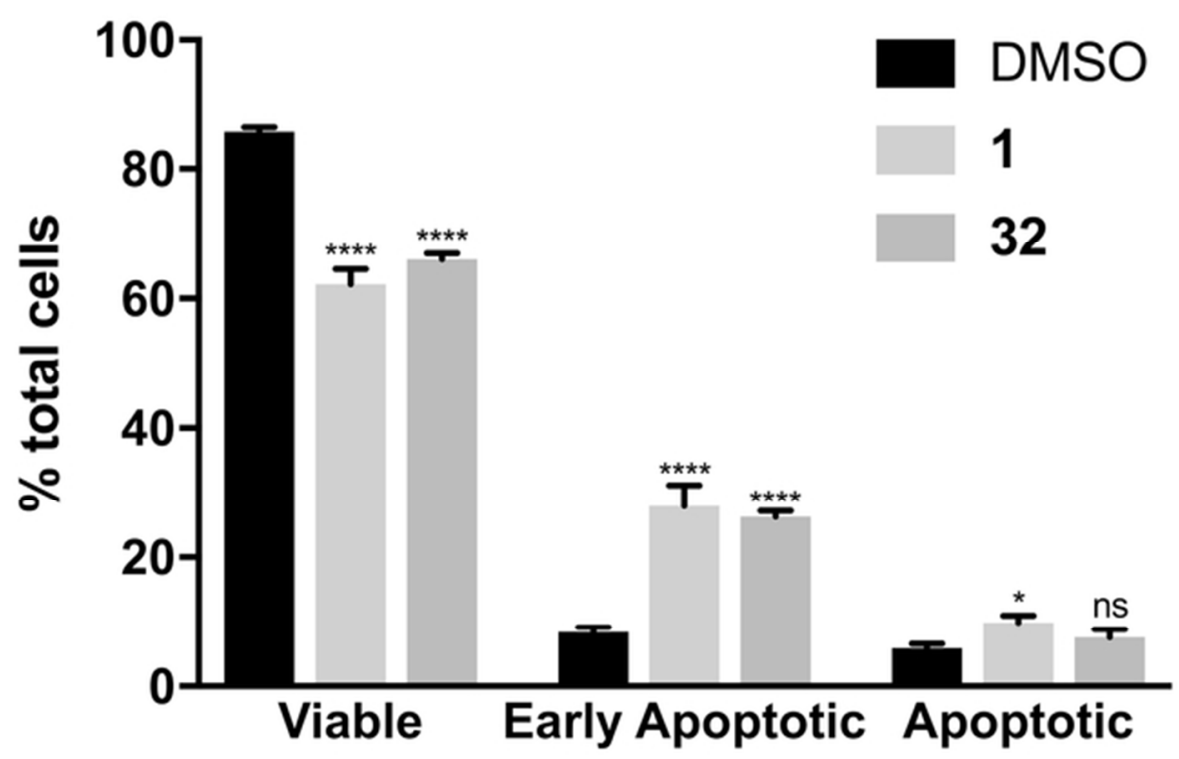

Figure 8. Annexin V-perCP EF710/7AAD double staining experiments results with THP-1 cell dosed with vehicle, or $10 \mu \mathrm{M} \mathbf{1}$ or $\mathbf{3 2}$ for 4 days in liquid culture. Early apoptotic cells = Annexin $\mathrm{V}^{\text {pos }} 7-\mathrm{AAD}^{\text {neg}}$; Apoptotic cells $=$ Annexin $V^{p o s} 7-A A D^{p o s} . * P<0.05, * * P<0.01, * * * P<0.001, * * * * P<0.0001$, statistical significance calculated using one-way ANOVA analysis with Dunnett's tests.

$60 \times 35 \mathrm{~mm}(300 \times 300 \mathrm{DPI})$ 